Prepared in cooperation with the Connecticut Department of Environmental Protection

\title{
Nutrient Loads and Ground-Water Residence Times in an Agricultural Basin in North-Central Connecticut
}

Scientific Investigations Report 2006-5278 


\section{Nutrient Loads and Ground-Water Residence Times in an Agricultural Basin in North-Central Connecticut}

By John R. Mullaney

Prepared in cooperation with the Connecticut Department of Environmental Protection

Scientific Investigations Report 2006-5278 


\title{
U.S. Department of the Interior DIRK KEMPTHORNE, Secretary
}

\author{
U.S. Geological Survey \\ Mark D. Myers, Director
}

\author{
U.S. Geological Survey, Reston, Virginia: 2007
}

For more information on the USGS—-the Federal source for science about the Earth, its natural and living resources,
natural hazards, and the environment:
World Wide Web: http://www.usgs.gov
Telephone: 1-888-ASK-USGS
Any use of trade, product, or firm names is for descriptive purposes only and does not imply endorsement
by the U.S. Government.
Although this report is in the public domain, permission must be secured from the individual copyright owners to
reproduce any copyrighted materials contained within this report.

Suggested citation:

Mullaney, J.R., 2007, Nutrient loads and ground-water residence times in an agricultural basin in north-central Connecticut: U.S. Geological Survey Scientific Investigations Report 2006-5278, 45 p. 


\section{Contents}

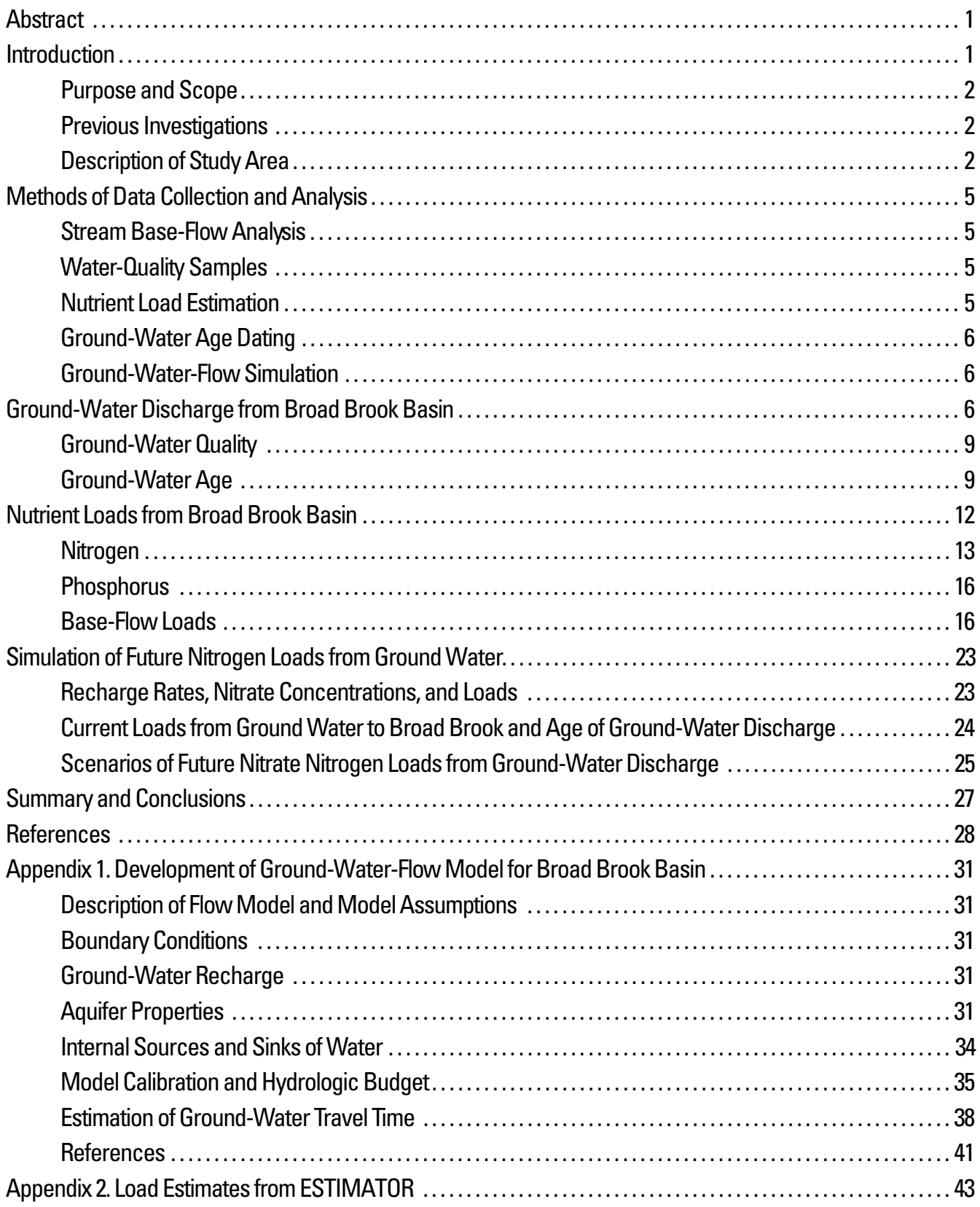




\section{Figures}

1-2. Maps showing:

1. Location of Broad Brook Basin, north-central Connecticut, and data-collection locations .... 3

2. Generalized surficial geology of Broad Brook Basin, north-central Connecticut 4

3-13. Graphs showing:

3. Estimated concentrations in precipitation of sulfur hexafluoride in North America and tritium at Ellington, Connecticut, 1954-2002

4. Estimated concentrations of tritium in precipitation at Ellington, Connecticut, decayed to 2004

5. Base flow and overland runoff at U.S. Geological Survey streamflow-gaging station 01184490, Broad Brook at Broad Brook, Connecticut, water years 1993-2004

6. Average monthly base flow and overland runoff at U.S. Geological Survey streamflowgaging station 01184490, Broad Brook at Broad Brook, Connecticut, water years 1993-2004

7. Relation between concentrations of sulfur hexafluoride and tritium and mixing models for younger (2001) and older pre-tracer water in Broad Brook Basin, north-central Connecticut....

8. Flow-duration curve and discharge conditions during sampling at Broad Brook at Broad Brook, Connecticut, water years 1993-2004

9. Nitrogen loads at U.S. Geological Survey station 01184490, Broad Brook at Broad Brook, Connecticut, for total nitrogen, nitrate nitrogen, and total ammonia plus organic nitrogen ... 14

10. Concentrations of total nitrogen by month at U.S. Geological Survey station 01184490, Broad Brook at Broad Brook, Connecticut, water years 1993-2004

11. Phosphorus loads at U.S. Geological Survey station 01184490, Broad Brook at Broad Brook, Connecticut, for (A) total phosphorus, and (B) dissolved phosphorus.

12. Base-flow loads at U.S. Geological Survey station 01184490, Broad Brook at Broad Brook, Connecticut, for (A) nitrate nitrogen and (B) dissolved phosphorus

13. Base-flow loads of nitrate nitrogen and total nitrogen loads from surface runoff at U.S. Geological Survey station 01184490, Broad Brook at Broad Brook, Connecticut ... 19

14-16. Maps showing:

14. Base-flow loads of total nitrogen from selected subbasins, September 18-20, 2002, Broad Brook Basin, north-central Connecticut

15. Base-flow loads of nitrite plus nitrate nitrogen from selected subbasins, September 18-20, 2002, Broad Brook Basin, north-central Connecticut

16. Base-flow loads of total phosphorus from selected subbasins, September 18-20, 2002, Broad Brook Basin, north-central Connecticut

17-18. Graphs showing:

17. Simulated cumulative curve of percent of ground-water discharge in year 2006 from Broad Brook Basin by simulated year/age of recharge

18. Simulated future base-flow load of nitrate nitrogen from Broad Brook Basin, north-central Connecticut, under five scenarios for reductions in concentration of nitrate in recharging ground water

Appendix 1 Figures

1-1. Map showing extent of finite-difference ground-water-flow model grid, boundary conditions, and zone arrays for recharge and hydraulic conductivity, Broad Brook Basin, north-central Connecticut

1-2. Generalized west-to east-cross section along row 38 in the finite-difference ground-waterflow model, showing model layers and hydraulic-conductivity zones, Broad Brook Basin, north-central Connecticut 
1-3. Map showing location of measurements of ground-water levels and streamflow, Broad Brook Basin, north-central Connecticut ............................. 36

1-4. Graph showing simulated and measured hydraulic head, Broad Brook Basin,

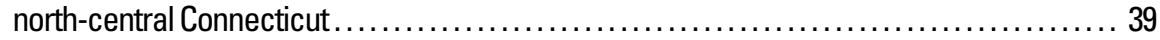

1-5. Graph showing simulated and measured streamflow, Broad Brook Basin, north-central Connecticut.

\section{Tables}

1. Water-quality data for samples from selected wells Broad Brook Basin, north-central Connecticut, 2004

2. Concentrations of sulfur hexafluoride and tritium and apparent ages of ground-water samples in Broad Brook Basin, north-central Connecticut .................................... 11

3. Concentrations, loads, and yields of nitrogen and phosphorus at U.S. Geological Survey station 01184490, Broad Brook at Broad Brook, Connecticut, 1993-2004 ........................... 16

4. Concentrations of nitrate nitrogen assigned to land-use and land-cover categories, and estimated load to the water table, Broad Brook Basin, north-central Connecticut ................... 23

5. Simulated future base-flow load of nitrate nitrogen from Broad Brook Basin, north-central Connecticut, under five scenarios for reductions in concentration of nitrate in recharging ground water

Appendix tables

1-1. Values of hydraulic conductivity used in finite-difference ground-water-flow model, Broad Brook Basin, north-central Connecticut .............................................. 34

1-2. Parameter estimates of hydraulic conductivity and recharge from nonlinear regression, finite-difference ground-water-flow model, Broad Brook Basin, north-central Connecticut ....... 35

1-3. Water levels in October 2003 and average water levels at selected U.S.Geological Survey network wells with long-term measurement records, Broad Brook Basin, north-central

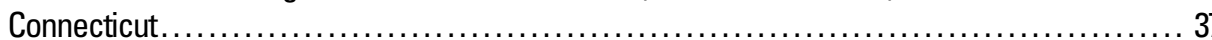

1-4. Summary of error statistics and comparison of observed and simulated ground-water levels, Broad Brook Basin, north-central, Connecticut, April 16-20, $2002 \ldots \ldots \ldots \ldots \ldots \ldots \ldots \ldots \ldots \ldots \ldots$

1-5. Model-calculated hydrologic budgetfor steady-state conditions $\ldots \ldots \ldots \ldots \ldots \ldots \ldots \ldots \ldots \ldots$

1-6. Simulated and apparent ages at selected monitoring wells, Broad Brook Basin,

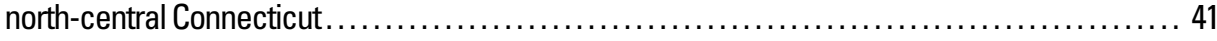

2-1. Load estimates from ESTIMATOR Log-Linear Regression for U.S. Geological Survey station 01184490, Broad Brook at Broad Brook, Connecticut 


\section{Conversion Factors and Datum}

\begin{tabular}{|c|c|c|}
\hline Multiply & By & To obtain \\
\hline \multicolumn{3}{|c|}{ Length } \\
\hline inch (in.) & 2.54 & centimeter $(\mathrm{cm})$ \\
\hline foot $(\mathrm{ft})$ & 0.3048 & meter $(\mathrm{m})$ \\
\hline \multicolumn{3}{|c|}{ Area } \\
\hline square mile $\left(\mathrm{mi}^{2}\right)$ & 2.590 & square kilometer $\left(\mathrm{km}^{2}\right)$ \\
\hline square foot $\left(\mathrm{ft}^{2}\right)$ & 0.09290 & square meter $\left(\mathrm{m}^{2}\right)$ \\
\hline \multicolumn{3}{|c|}{ Flow rate } \\
\hline cubic foot per second $\left(\mathrm{ft}^{3} / \mathrm{s}\right)$ & 0.02832 & cubic meter per second $\left(\mathrm{m}^{3} / \mathrm{s}\right)$ \\
\hline gallon per day (gal/d) & 0.003785 & cubic meter per day $\left(\mathrm{m}^{3} / \mathrm{d}\right)$ \\
\hline million gallons per day (Mgal/d) & 0.04381 & cubic meter per second $\left(\mathrm{m}^{3} / \mathrm{s}\right)$ \\
\hline inch per year (in/yr) & 25.4 & millimeter per year (mm/yr) \\
\hline \multicolumn{3}{|c|}{ Mass } \\
\hline pound, avoirdupois (lb) & 0.4536 & kilogram (kg) \\
\hline $\begin{array}{l}\text { pound per square mile per year } \\
\left(\mathrm{lb} / \mathrm{mi}^{2} / \mathrm{yr}\right)\end{array}$ & & $\begin{array}{l}\text { kilogram per square kilometer per year } \\
\left(\mathrm{kg} / \mathrm{km}^{2} / \mathrm{yr}\right)\end{array}$ \\
\hline \multicolumn{3}{|c|}{ Hydraulic conductivity } \\
\hline foot per day (ft/d) & 0.3048 & meter per day $(\mathrm{m} / \mathrm{d})$ \\
\hline \multicolumn{3}{|c|}{ Transmissivity* } \\
\hline foot squared per day $\left(\mathrm{ft}^{2} / \mathrm{d}\right)$ & 0.09290 & meter squared per day $\left(\mathrm{m}^{2} / \mathrm{d}\right)$ \\
\hline
\end{tabular}

Temperature in degrees Celsius $\left({ }^{\circ} \mathrm{C}\right)$ may be converted to degrees Fahrenheit $\left({ }^{\circ} \mathrm{F}\right)$ as follows:

${ }^{\circ} \mathrm{F}=\left(1.8 \mathrm{x}^{\circ} \mathrm{C}\right)+32$

Temperature in degrees Fahrenheit $\left({ }^{\circ} \mathrm{F}\right)$ may be converted to degrees Celsius $\left({ }^{\circ} \mathrm{C}\right)$ as follows:

${ }^{\circ} \mathrm{C}=\left({ }^{\circ} \mathrm{F}-32\right) / 1.8$

Vertical coordinate information is referenced to the North American Vertical Datum of 1988 (NAVD 88).

Altitude, as used in this report, refers to distance above the vertical datum.

Transmissivity: The standard unit for transmissivity is cubic foot per day per square foot times foot of aquifer thickness $\left[\left(\mathrm{ft}^{3 /} \mathrm{d}\right) / \mathrm{ft}^{2}\right] \mathrm{ft}$. In this report, the mathematically reduced form, foot squared per day $\left(\mathrm{ft}^{2} / \mathrm{d}\right)$, is used for convenience.

Specific conductance is given in microsiemens per centimeter at 25 degrees Celsius $(\mu \mathrm{S} / \mathrm{cm}$ at $\left.25^{\circ} \mathrm{C}\right)$.

Concentrations of chemical constituents in water are given in milligrams per liter ( $\mathrm{mg} / \mathrm{L})$.

Concentrations of sulfur hexafluoride are given in parts per trillion by volume (pptv).

Concentrations of tritium are given in tritium units (TU). 


\title{
Nutrient Loads and Ground-Water Residence Times in an Agricultural Basin in North-Central Connecticut
}

\author{
by John R. Mullaney
}

\section{Abstract}

Nutrient loads from ground-water discharge were studied in Broad Brook Basin, a 15.8-square mile basin in north-central Connecticut, dominated by agricultural activity. Loads were calculated, along with the travel times of ground water from recharge to discharge areas, to estimate the time required for the effects of Best Management Practices (BMPs) to be observed. Most concentrations of nitrogen and phosphorus in Broad Brook exceeded U.S. Environmental Protection Agency Ecoregion XIV nutrient criteria for streams. During the study period (1993-2004), annual loads of nitrogen from Broad Brook Basin ranged from 117,000 to 270,000 pounds (lb), and yields were about 10 times larger than those from forested basins in Connecticut.

Ground-water discharge from the aquifer to the streams (base flow) during the study period was estimated with hydrograph separation and accounted for 82 percent of the total runoff from the basin. Nitrate nitrogen in base flow averaged 71 percent of the annual load of total nitrogen discharged from the basin, indicating that the largest source of nitrogen was likely from ground-water discharge. Annual loads of total phosphorus from the basin ranged from 2,330 to $14,400 \mathrm{lb}$, and yields were about five times higher than those from forested basins in Connecticut. Dissolved phosphorus averaged about 71 percent of the total phosphorus load, and ground-water discharge accounted for only as much as 40 percent of the annual load of dissolved phosphorus; therefore, phosphorus loads are dominated by stormwater-runoff events.

Ground-water samples collected from 11 wells in the basin contained elevated concentrations of nitrite plus nitrate nitrogen. Dissolved gas analyses indicated that little denitrification was occurring in the aquifer. Apparent ages of the ground-water samples ranged from greater than 2 to more than 50 years based on sulfur hexafluoride, tritium, and tritium/helium-3 analyses. A three-dimensional ground-water-flow model was used in conjunction with a particle-tracking program to determine advective travel times to streams from all subareas in the basin. The model simulations indicated that about half the discharge to Broad Brook and its tributaries was recharged more than 10 years ago, and that about 8 percent of the discharge was recharged prior to 1960 .

The effects of changes in nitrate nitrogen loading at the water table were evaluated by applying new loading rates from urban and agricultural land and the simulated advective groundwater travel times. Five scenarios were tested: reducing estimated nitrate nitrogen concentrations in recharging ground water under urban and agricultural land areas to concentrations in forested areas; reducing estimated nitrate nitrogen concentrations under urban and agricultural land areas to the U.S. Environmental Protection Agency recommended nutrient criteria for streams; and reducing estimated nitrate nitrogen concentrations under urban and agricultural land areas by 50 percent, 10 percent, and 5 percent. Under the first two scenarios, the base-flow load of nitrate nitrogen could be reduced by 25 percent in slightly more than 5 years, although the reduction required by these scenarios is likely unrealistic. A 25-percent reduction in base-flow load of nitrate nitrogen could be achieved in about 10 years under the third scenario (where concentrations from urban and agricultural areas were reduced by 50 percent). Under this scenario, a 46-percent reduction could be achieved in about 60 years. The scenarios indicate that in this basin, and in other similar basins in Connecticut underlain by extensive glacial stratified deposits, there can be a substantial time lag between activities at the land surface and effects on the quality of water discharged to streams from ground water. This finding may be important in the expectations for water-quality improvements from land-use changes or BMPs.

\section{Introduction}

Long Island Sound is an important resource for southern New England and New York. Nitrogen enrichment during the summer, which causes low concentrations of dissolved oxygen (less than 3.5 milligrams per liter $(\mathrm{mg} / \mathrm{L})$ ), is one of the major problems in the Sound. Excess nitrogen promotes excessive growth of algae (algal blooms), which eventually die and sink to the bottom. The subsequent decomposition of the algae consumes oxygen in the bottom waters of the Sound (New York Dept. of Environmental Conservation/Connecticut Dept. of Environmental Protection, 2000). Sources of nitrogen to the Sound include direct and indirect discharges of wastewater (point sources), and runoff from urban and agricultural land and atmospheric deposition (nonpoint sources). Attempts to limit nitrogen loads to the Sound include a limit on point and nonpoint nitrogen loads at 1990 levels in designated areas (New York Dept. of Environmental Conservation/Connecticut Dept. 


\section{Nutrient Loads and Ground-Water Residence Times in an Agricultural Basin in North-Central Connecticut}

of Environmental Protection, 2000), and adoption of a plan by three agencies - New York Dept. of Environmental Conservation (NYDEC), the Connecticut Dept. of Environmental Protection (CTDEP), and the U.S. Environmental Protection Agency (USEPA) - to reduce nitrogen loads associated with human activities by 58.5 percent in 11 management zones in New York and Connecticut.

Ground water plays an important role in the delivery of nutrients to streams that discharge to Long Island Sound and by direct discharge to the Sound; however, the role of groundwater discharge often is not considered in the implementation of Best Management Practices (BMPs) to reduce nitrogen loads. In basins with extensive glacial stratified deposits, groundwater discharge dominates the annual discharge of water to streams (Thomas, 1966). It also has been recognized that ground-water discharge from high-intensity agricultural areas can contain high concentrations of nitrate nitrogen (Frink, 1969). Broad Brook Basin (fig. 1), in north-central Connecticut, contains extensive stratified glacial deposits and is a high-intensity agricultural area. The basin has been identified by the CTDEP as having impaired water quality because of agricultural activities (Connecticut Dept. of Environmental Protection, 2004). In addition, the U.S. Geological Survey (USGS) has determined that Broad Brook Basin has the largest nonpoint yield of nitrogen of any basin sampled routinely in Connecticut (Mullaney and others, 2002). To improve the understanding of the role of ground-water discharge in nitrogen loading, the USGS and the CTDEP conducted a cooperative groundwater/water-quality study from 2002 to 2005 in Broad Brook Basin. An understanding of the quantity of nutrients entering the stream from the ground-water system and the travel time from source areas to the discharge point will assist CTDEP in determining the most effective BMPs and in calculating total maximum daily loads (TMDLs).

\section{Purpose and Scope}

This report presents the results of the USGS/CTDEP study of nutrient loads in Broad Brook Basin, with a focus on loads from ground water. Specifically, the report includes (1) relative loads of nitrate nitrogen and other nutrients from ground water and surface water, (2) the spatial distribution of nitrate loading in Broad Brook Basin from the ground-water system, (3) ground-water travel times from recharge to discharge areas, and (4) estimates of the time necessary to observe changes in surface-water quality following implementation of BMPs that focus on ground-water-quality improvements.

\section{Previous Investigations}

The water quality of Broad Brook Basin has been studied in several previous investigations. A study of the relations between land use and ground-water quality included samples from shallow wells in Broad Brook Basin (Grady, 1994). That study determined that nitrite-plus-nitrate nitrogen concentra- tions were elevated in the basin; concentrations as large as $60 \mathrm{mg} / \mathrm{L}$ were reported in shallow ground-water samples downgradient from agricultural areas. Clausen and others (2000) studied Muddy Brook Basin, a subbasin of Broad Brook Basin (fig. 1), to determine the effectiveness of riparian buffer restoration on water quality. Mullaney (1995) investigated the hydrogeology and estimated ground-water discharge from the Muddy Brook site. Mullaney and Zimmerman (1997) studied the runoff of nutrients and herbicides from Broad Brook Basin during a storm event in 1992 and noted that concentrations of nitrite-plus-nitrate nitrogen were largest in samples collected during base flow. Concentrations of ammonia-plus-organic nitrogen were largest in samples collected during storm-flow conditions. Trench (2000) analyzed nutrient loads for the National Water-Quality Assessment Program (NAWQA) and determined that annual loads of nitrogen from Broad Brook Basin ranged from 167,000 to 228,000 pounds (lb) during 1993-95. Yields of nitrogen and phosphorus from the basin were as large as those from basins with multiple municipal wastewater-treatment facilities. Mullaney and others (2002) further analyzed total nitrogen load (through 1998) from Broad Brook, as part of developing a generalized least-squares regression model to estimate nonpoint nitrogen loads to Long Island Sound. Nitrogen yields from Broad Brook Basin were considered anomalously high when compared to other basins dominated by agricultural land use.

\section{Description of Study Area}

Broad Brook Basin, in north-central Connecticut, drains an area of 15.8 square miles $\left(\mathrm{mi}^{2}\right)$ and is part of the Scantic River regional basin (fig. 1). The altitude of the land surface ranges from about 40 feet (ft) at the basin outlet to about $860 \mathrm{ft}$ on the northeastern boundary of the watershed. Land cover in the basin is about 42 percent agricultural land, 13 percent urban land, and 45 percent forest and wetlands, based on land cover developed by Civco and others (1998). Major agricultural crops include silage corn for dairy farming, nursery stock, vegetables, and tobacco.

The surficial geology of Broad Brook Basin has been previously mapped by Colton $(1965,1972)$ and by Stone and others $(1992,2005)$. The basin is underlain by glacial stratified deposits (54 percent), and glacial till (46 percent) (fig. 2). The surficial deposits are underlain by two different bedrock terranes: the lowlands in the western part of the basin are underlain by Mesozoic arkosic bedrock of the Portland Formation, and the eastern highlands are underlain by crystalline bedrock that includes gneiss, granitic gneiss, and dolerite (Rodgers, 1985). The two major terranes are divided by the eastern border fault (fig. 2). The bedrock of the Portland Formation dips to the east at 11-12 degrees (Rodgers, 1985).

Average precipitation in Broad Brook Basin was about 48.5 inches per year (in/yr) for the period 1980-97 (University of Montana, Numerical Terradynamic Simulation Group, 2006). Annual mean runoff was $22.7 \mathrm{in} / \mathrm{yr}$ based on data from USGS streamflow-gaging station 01184490 (Broad Brook at 


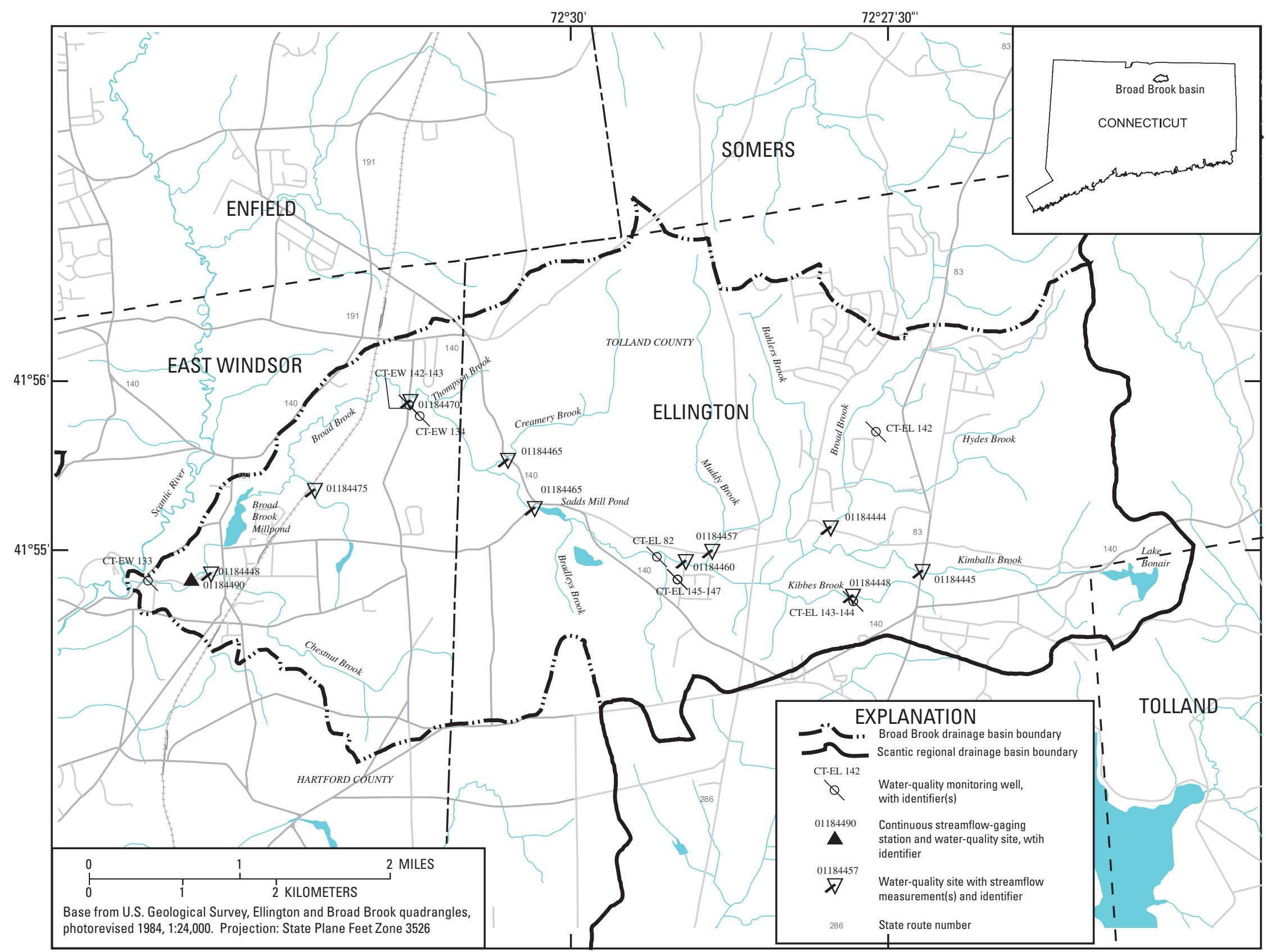

Figure 1. Location of Broad Brook Basin, north-central Connecticut, and data-collection locations. 


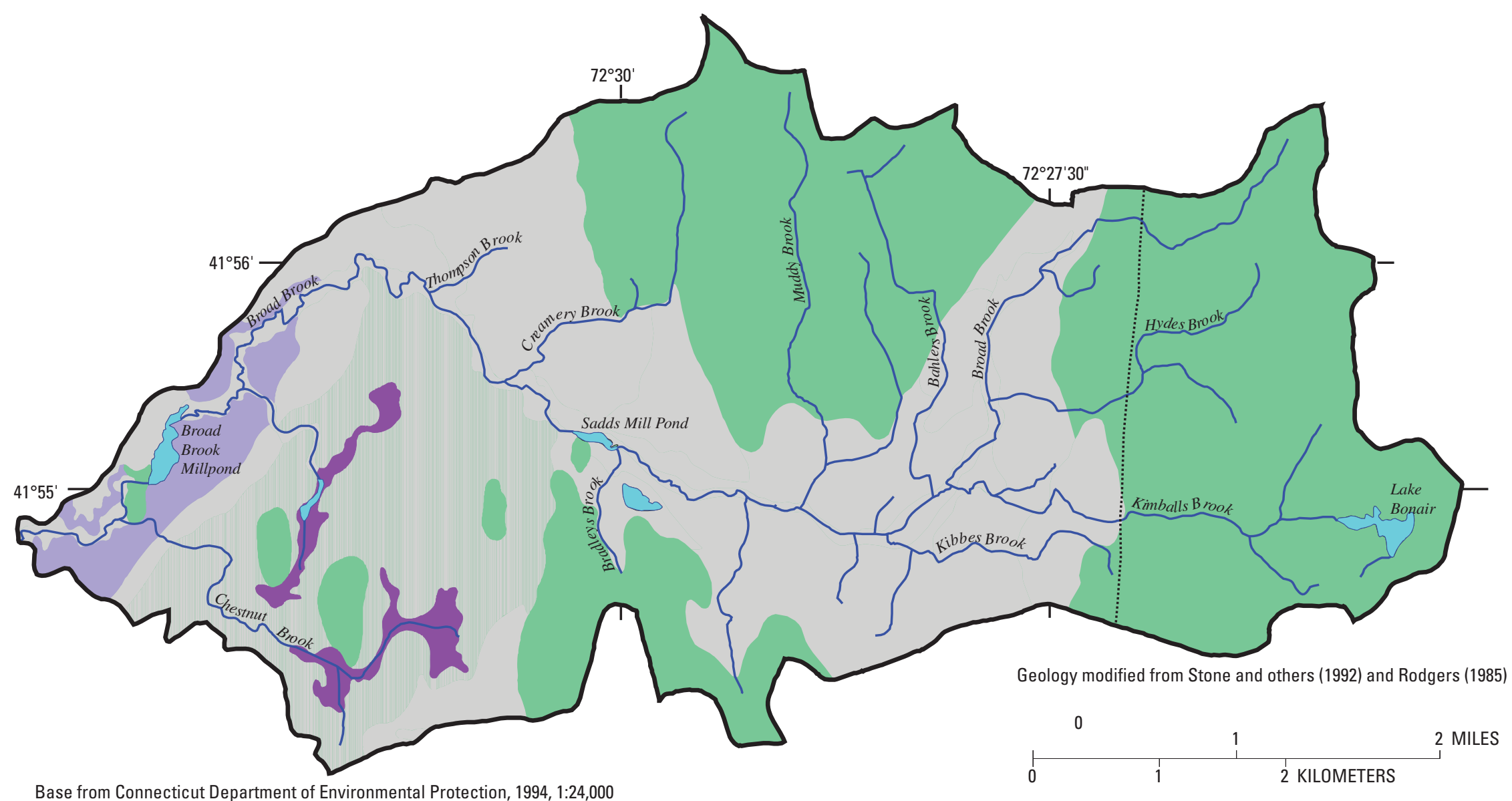
Projection: State Plane Feet Zone 3526

\section{EXPLANATION}

Swamp deposits

Glacial stratified deposits, fine grained

Glacial stratified deposits, coarse grained

Till

Eastern Border Fault

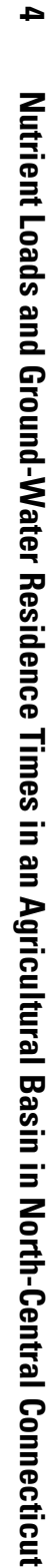

Figure 2. Generalized surficial geology of Broad Brook Basin, north-central Connecticut. 
Broad Brook, Connecticut) for water years ${ }^{1}$ 1993-2004. Recharge in Connecticut typically is 20 to $25 \mathrm{in} / \mathrm{yr}$ to glacial stratified deposits and 8 to $10 \mathrm{in} / \mathrm{yr}$ to glacial till deposits and till-covered bedrock (Mazzaferro and others, 1979). Mullaney and Zimmerman (1997) reported that the long-term base flow from Broad Brook Basin was 18.3 in/yr during 1983-94.

\section{Methods of Data Collection and Analysis}

The study of Broad Brook Basin included an analysis of existing water-quality and streamflow data collected at USGS station 01184490 (fig. 1) to determine (1) the annual load of total nitrogen and (2) the load of nitrate-nitrogen during base flow. A low-flow water-quality and streamflow survey was conducted during September 2002 to estimate nitrogen loads from ground water at 11 sites (fig. 1). Ground-water samples were collected from April to May 2004 from existing and newly drilled monitoring wells; samples were analyzed for concentrations of nutrients and dissolved gases, and for determination of ground-water age. Water levels and streamflows were measured during October 2003 (a period of typical base-flow conditions) for use in calibrating a steady state, finite-difference ground-water-flow model. The ground-water-flow model (appendix 1) was used to simulate ground-water flow in Broad Brook Basin to evaluate future scenarios for nitrogen-load reduction from ground water.

\section{Stream Base-Flow Analysis}

Stream base flow was analyzed to determine the groundwater-discharge component of streamflow at the Broad Brook streamflow-gaging station (01184490, fig. 1). This information was used along with water-quality data to determine base-flow loads of nitrate nitrogen from 1993 to 2004. Stream base-flow analysis was done using the computer program "PART" and methods described by Rutledge (1998).

\section{Water-Quality Samples}

As part of the USGS/CTDEP cooperative water-quality network, surface-water-quality samples were collected at the Broad Brook streamflow-gaging station (01184490, fig. 1) eight times or more each water year from 1997 to 2004. Samples also were collected from 1993-1995 as part of the USGS NAWQA program. Subsets of these data were used by Trench (2000) and Mullaney and others (2002) to estimate nutrient loads from Broad Brook Basin. Surface-water samples also were collected from 10 additional sites (fig. 1) throughout the basin during low-flow conditions for analysis of nitrogen and phosphorus concentrations. Samples were collected in accordance with procedures described in Wilde and Radtke (1998). All surface water-quality samples were analyzed by the USGS National Water-Quality Laboratory in Denver, Colorado.

Ground-water-quality samples were collected from April to May 2004 from 11 monitoring wells (fig. 1): four existing wells from other USGS studies in Broad Brook Basin and seven wells installed in September 2003. Wells were selected or installed at multiple depths and locations in the glacial stratified deposits. Ground-water samples were analyzed for concentrations of nitrogen and phosphorus, dissolved gases, and for determination or ground-water age. Ground water was sampled to provide data on variations in nutrient concentrations in the aquifer (spatially and vertically) and to determine apparent age of ground water for use in a ground-water-flow simulation. Samples were collected in accordance with the procedures described in Wilde and Radtke (1998). All ground-water samples for nutrient concentrations were analyzed by the USGS National Water-Quality Laboratory in Denver, Colorado.

\section{Nutrient Load Estimation}

Nutrient loads were estimated using the computer program ESTIMATOR (Cohn and others 1992a), which uses a multiple linear-regression model to estimate loads from observations of streamflow and concentration. The method uses the Minimum Variance Unbiased Estimator (MVUE) to account for retransformation bias (Cohn and others, 1989; Gilroy and other, 1990; Cohn and others, 1992a) associated with the log-transformed dependent variable (flow), and incorporates an adjusted maximum-likelihood estimator for data sets that contain values below a detection limit (Cohn, 1988; Cohn and others, 1992b).

The data used in the regression model include concentration data from 1993 to 2004 and the corresponding mean daily discharge values for USGS station 01184490 (Broad Brook at Broad Brook). These values were used to develop a regression equation for each constituent that was subsequently used to make daily estimates of load based on the daily flow record. Average daily loads were aggregated by water year, and confidence intervals were calculated. Load estimates for water year 1996 (a year with no water-quality data) were made using ESTIMATOR. Nutrient yields were calculated by dividing loads from station 01184490 by the drainage area of $15.5 \mathrm{mi}^{2}$.

Nutrient concentration data and mean daily discharge values were retrieved from the USGS National Water Information System (NWIS) database (http://waterdata.usgs.gov/ct/nwis/). Concentrations of total nitrogen were calculated as the sum of the concentrations of nitrite plus nitrate and total ammonia plus organic nitrogen.

Nitrogen loads in base flow also were estimated using ESTIMATOR and a subset of concentration data collected dur-

\footnotetext{
${ }^{1}$ A water year is defined as the 12-month period October 1 through September 30. The water year is designated by the calendar year in which it ends and which includes 9 of the 12 months. Thus, the year ending September 30, 2004, is called the 2004 water year.
} 


\section{Nutrient Loads and Ground-Water Residence Times in an Agricultural Basin in North-Central Connecticut}

ing base-flow conditions. Samples were determined to represent base-flow conditions by using the output from the hydrograph separation program PART. Samples were classified as collected during base flow if the estimated daily base flow was 95 percent or more of the mean daily streamflow. The daily base-flow record, estimated using PART, was used to estimate base-flow loads of nitrogen and phosphorus.

\section{Ground-Water Age Dating}

Ground-water age determinations were done by two methods: (1) sulfur hexafluoride $\left(\mathrm{SF}_{6}\right)$ and (2) tritium/helium-3 $\left({ }^{3} \mathrm{H} /{ }^{3} \mathrm{He}\right)$. Dissolved gas analyses $\left(\mathrm{N}_{2}, \mathrm{Ar}, \mathrm{O}_{2}, \mathrm{CO}_{2}\right.$ and $\left.\mathrm{CH}_{4}\right)$ were used to determine ground-water recharge temperature and the amount of excess air present in the samples. Excess air is entrained in the recharge as it makes its way to the water table or by the rise of the water table. Excess air increases the $\mathrm{SF}_{6}$ concentration above the air-water equilibrium (Busenberg and Plummer, 2000). Recharge temperature and excess air were determined from the measurements of $\mathrm{N}_{2}$ and Ar gas present in the sample as described by Lindsey and others (2003) and Busenberg and Plummer (2000). Dissolved gas measurements also were used to determine whether excess nitrogen gas was present, an indicator of denitrification in the ground-water-flow system.

Sulfur hexafluoride $\left(\mathrm{SF}_{6}\right)$ is a compound that has been accumulating in the atmosphere due to the increasing release from the manufacture of electrical switching components (fig. 3 ). Concentrations in ground water can be compared with the atmospheric input to estimate an apparent age. The method is limited to waters recharged after 1970. The method is described in detail by Busenberg and Plummer (2000) and by Lindsey and others (2003).

The $\mathrm{SF}_{6}$ method has some limitations that may bias the age of ground water. For instance, there are some natural sources of $\mathrm{SF}_{6}$ in crystalline rocks (Busenberg and Plummer 2000), and the input function of atmospheric $\mathrm{SF}_{6}$ may vary by location. For instance, atmospheric inputs may be larger and highly variable downwind of more concentrated sources of release (Santella and others, 2003). Samples for ground-water age interpretation (sulfur hexafluoride) and dissolved gas concentrations were analyzed by the USGS Chlorofluorocarbon Laboratory, in Reston, Virginia.

Tritium/helium-3 $\left({ }^{3} \mathrm{H} /{ }^{3} \mathrm{He}\right)$ dating is the second method that was used to determine apparent ground-water age. The method works on the principle that atmospheric tritium $\left({ }^{3} \mathrm{H}\right)$, produced primarily from nuclear weapons testing in the 1960's, is contained in ground-water recharge (fig. 3 ). ${ }^{3} \mathrm{H}$ decays radioactively to Helium-3 $\left({ }^{3} \mathrm{He}\right)$, with a half-life of 12.4 years. When the recharge is isolated from the atmosphere and moves within the aquifer, the age of the water can be calculated by determin- ing relative amounts of ${ }^{3} \mathrm{He}$ and ${ }^{3} \mathrm{H}$. This method was described by Schlosser and others (1988), Solomon and Sudicky (1991), and Plummer and others (1993). In addition, measurements of ${ }^{3} \mathrm{H}$ can be used to qualitatively determine ground-water age, based on the estimated input function of ${ }^{3} \mathrm{H}$ from the atmosphere radioactively decayed to present concentrations (fig. 4). For instance, ground water recharged prior to nuclear-weapons testing in the mid-1950s should have concentrations of less than 2 tritium units (TU); concentrations of $30 \mathrm{TU}$ or more may indicate samples recharged during the peak of atmospheric nuclear testing in 1964 (fig. 4). Samples for ${ }^{3} \mathrm{H} /{ }^{3} \mathrm{He}$ ground-water-age interpretation were analyzed by the Lamont Doherty Earth Observatory of Columbia University at Palisades, New York.

\section{Ground-Water-Flow Simulation}

Ground-water flow in Broad Brook Basin was simulated using MODFLOW-2000 (Harbaugh and others, 2000), and MODPATH (Pollock, 1994). MODFLOW-2000 is a threedimensional, finite-difference ground-water-flow model that includes a nonlinear-regression algorithm to find the best fit among model parameters and hydrologic observations. MODPATH was used to simulate pathlines and ground-water travel times to understand the effects that ground-water travel times have on the discharge of nitrate nitrogen to Broad Brook. The model created for this study was a steady-state model to simulate long-term average conditions. Details of the model development and results are presented in appendix 1.

\section{Ground-Water Discharge from Broad Brook Basin}

The hydrograph separation using PART indicated that the average ground-water discharge from Broad Brook Basin at USGS station 01184490 for water years 1993-2004 was 18.6 $\mathrm{in} / \mathrm{yr}$, and the annual mean runoff from the basin for the same period was $22.7 \mathrm{in}$. This indicates that the base-flow component of streamflow (fig. 5), which represents the ground-water discharge, is about 82 percent of the annual streamflow. The largest base flows at USGS station 01184490 from 1993-2004 typically were from December to June (fig. 6), which is when most ground-water recharge occurs in Connecticut. Base flows from July to October accounted for only about 20 percent of the average annual base flow, whereas base flows in March to June accounted for about 47 percent. 


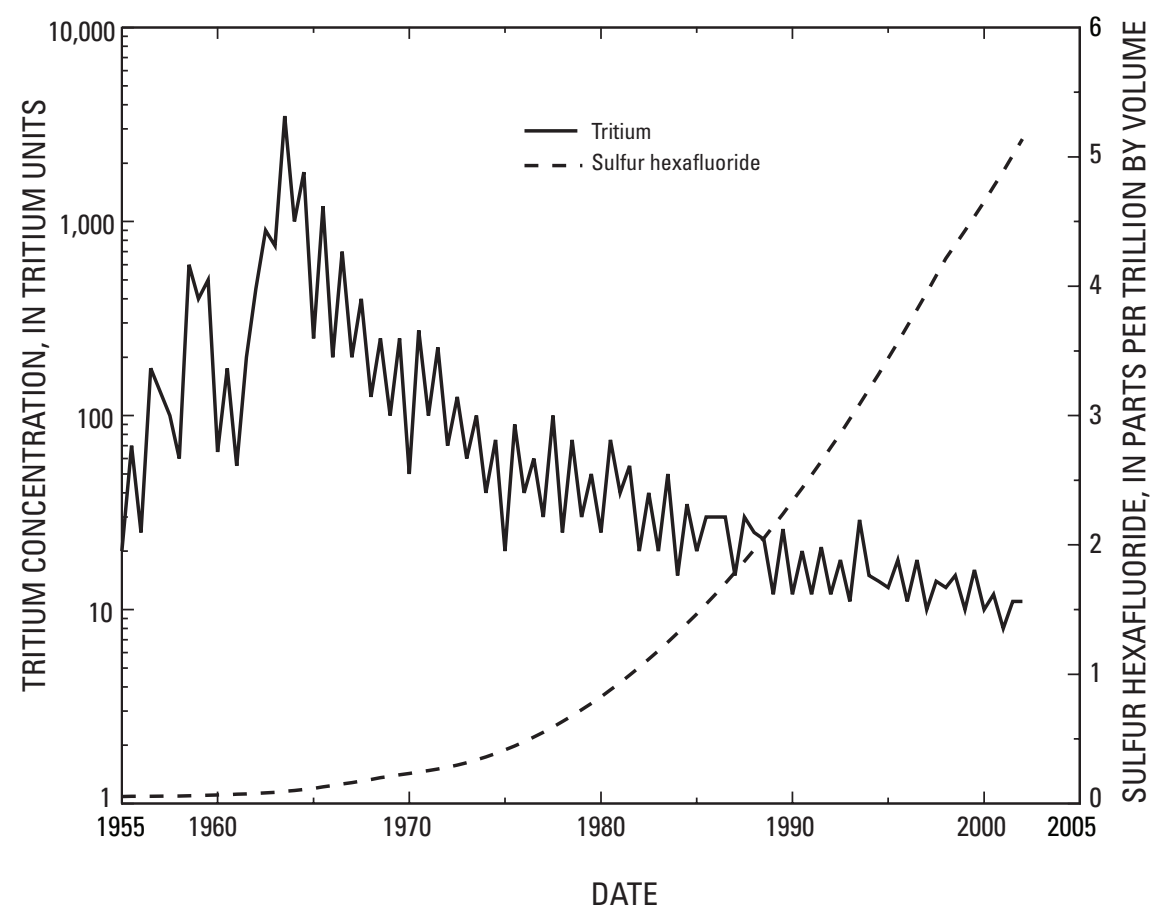

Figure 3. Estimated concentrations in precipitation of sulfur hexafluoride (Busenberg and Plummer, 2000), in North America and tritium at Ellington, Connecticut, 1954-2002 (R.L. Michel, U.S. Geological Survey, written commun. 2005).

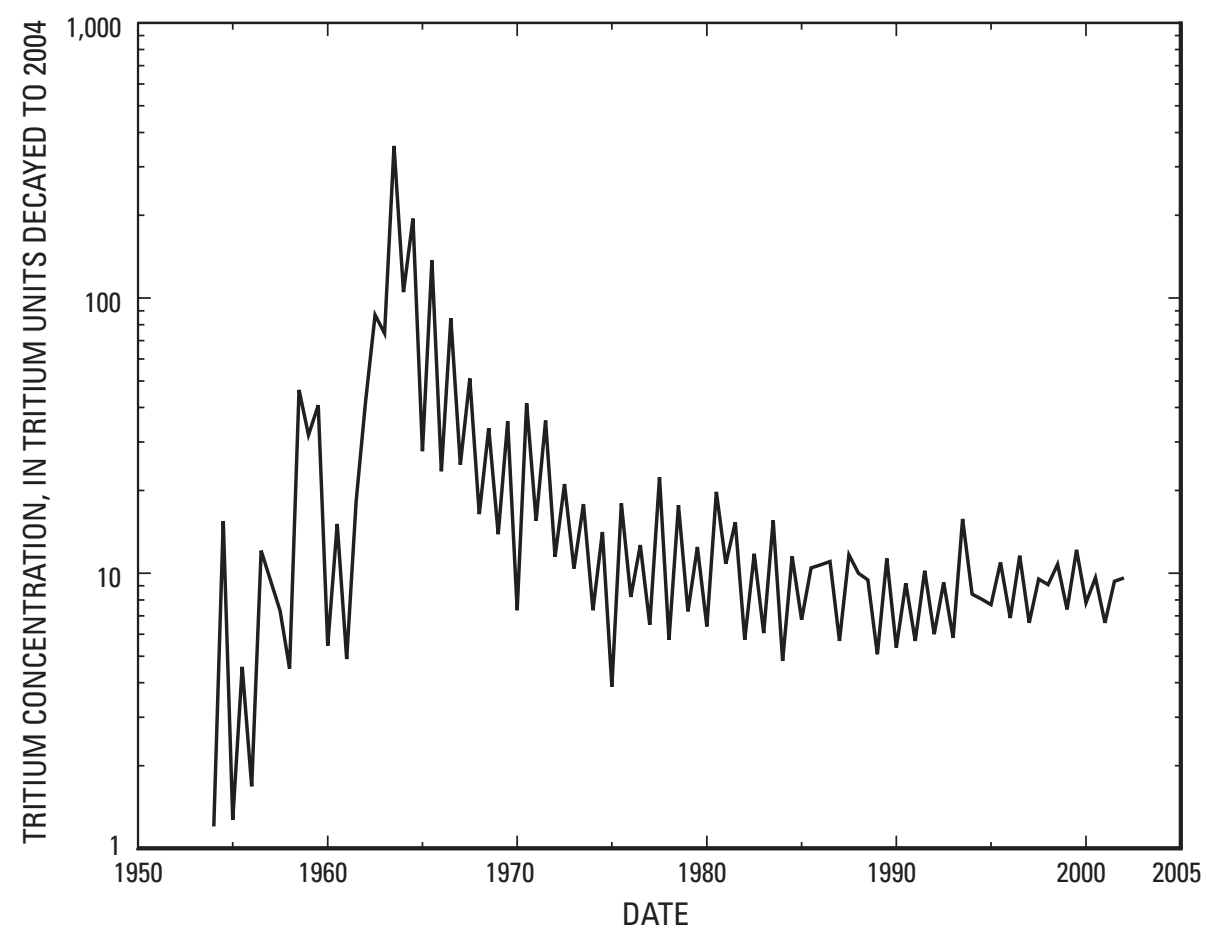

Figure 4. Estimated concentrations of tritium in precipitation at Ellington, Connecticut, decayed to 2004 (R.L Michel, U.S. Geological Survey, written commun. 2005). 


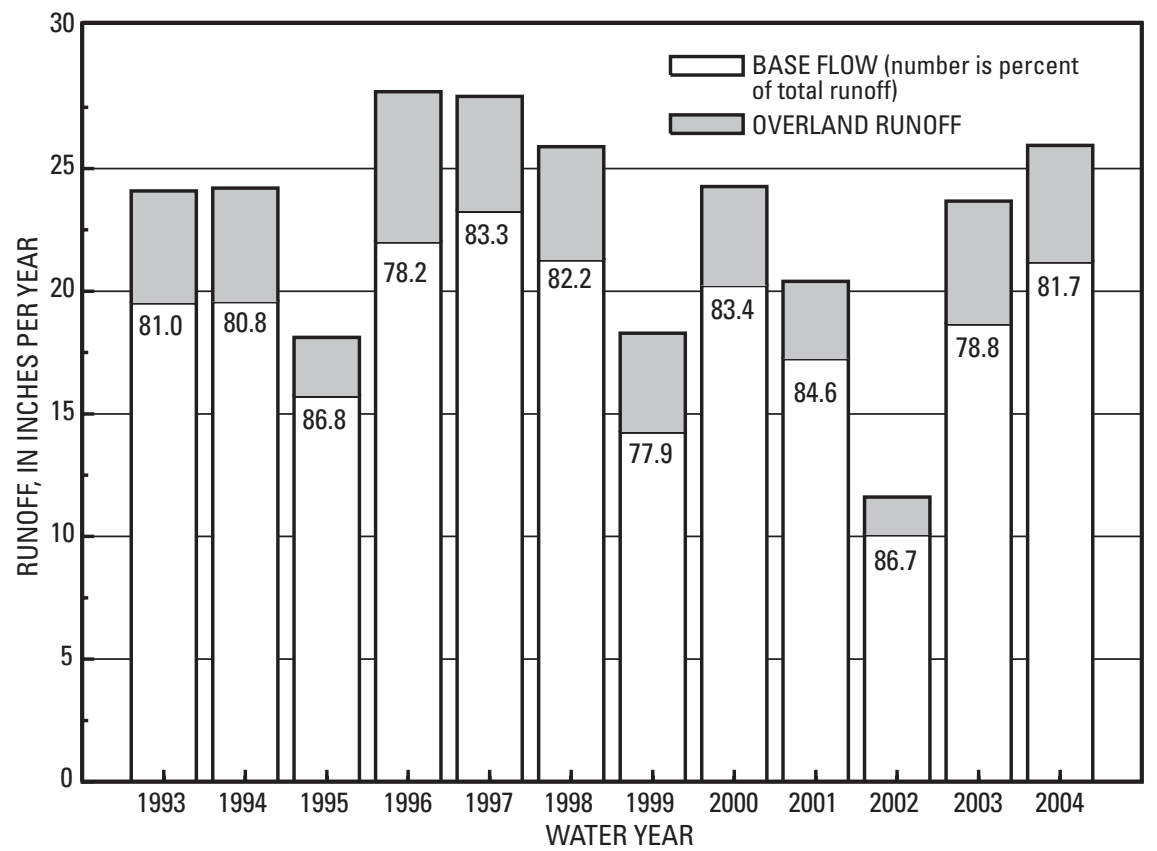

Figure 5. Base flow and overland runoff at U.S. Geological Survey streamflow-gaging station 01184490, Broad Brook at Broad Brook, Connecticut, water years 1993-2004.

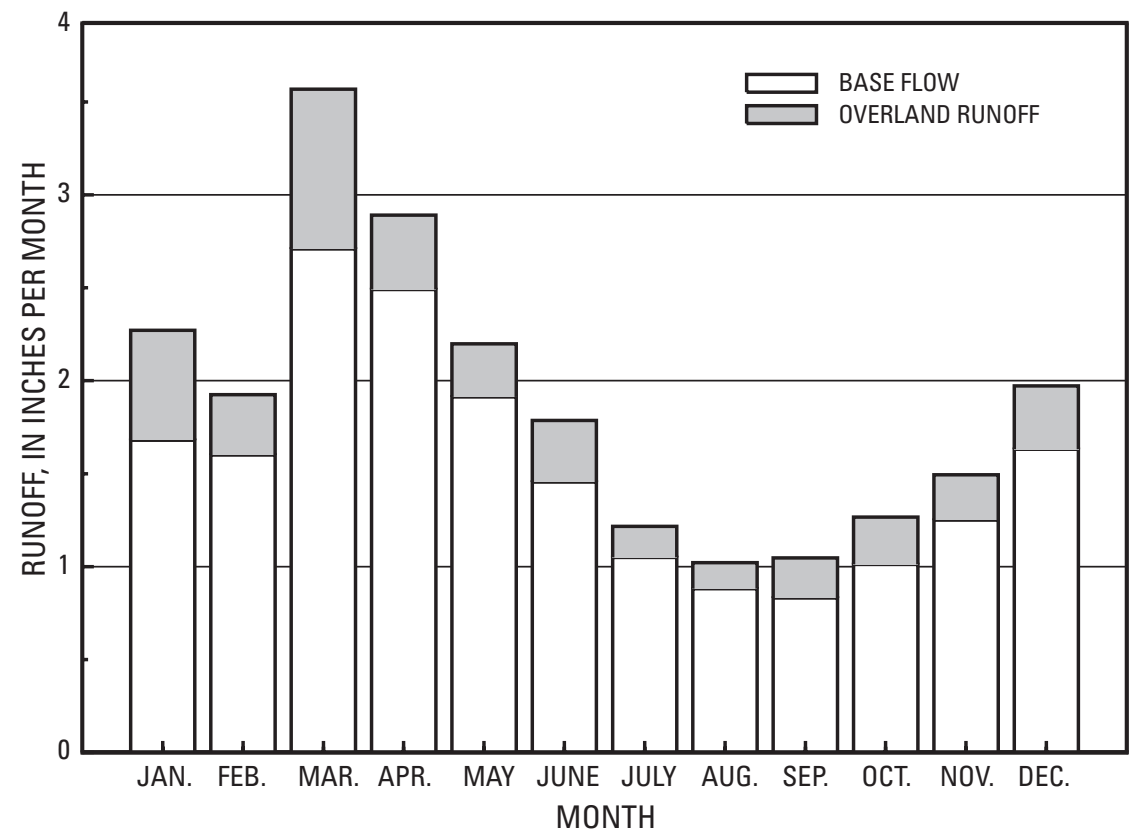

Figure 6. Average monthly base flow and overland runoff at U.S. Geological Survey streamflowgaging station 01184490, Broad Brook at Broad Brook, Connecticut, water years 1993-2004. 


\section{Ground-Water Quality}

Samples were collected from 11 monitoring wells in Broad Brook Basin from April to May 2004. Samples were analyzed for concentrations of nitrogen and phosphorus constituents (table 1), and ground-water age was interpreted from $\mathrm{SF}_{6}$, ${ }^{3} \mathrm{H} /{ }^{3} \mathrm{He}$, and dissolved gas measurements. Concentrations of nitrite plus nitrate nitrogen ranged from less than the reporting limit of 0.06 to $9.7 \mathrm{mg} / \mathrm{L}$. Concentrations in most samples collected were higher than the ambient concentrations for undeveloped forested areas (median value $0.11 \mathrm{mg} / \mathrm{L}$ reported by Grady (1994) and median value $0.14 \mathrm{mg} / \mathrm{L}$ reported by Grady and Mullaney (1998)). Concentrations as large as $60 \mathrm{mg} / \mathrm{L}$ of nitrite plus nitrate nitrogen have been measured in ground water during previous USGS studies in Broad Brook Basin (Grady, 1994; Cervione and others, 1989, p. 272).

Dissolved gas measurements $\left(\mathrm{N}_{2}, \mathrm{Ar}, \mathrm{O}_{2}, \mathrm{CO}_{2}\right.$ and $\left.\mathrm{CH}_{4}\right)$ that were used to determine excess air and recharge temperature for $\mathrm{SF}_{6}$ ground-water ages also can be used to estimate excess nitrogen gas produced due to denitrification of nitrate. Samples from wells CT-EL 143 and CT-EL 144 contained low concentrations (less than $2 \mathrm{mg} / \mathrm{L}$ ) of dissolved oxygen and low or undetected concentrations of nitrite plus nitrate nitrogen. Samples from these two wells also had excess nitrogen gas, indicating the possibility that the original nitrate nitrogen concentrations may have been 2 to $3 \mathrm{mg} / \mathrm{L}$ higher, and that denitrification has taken place. Wells CT-EL 143 and CT-EL 144 penetrate some buried organic sediments that may be facilitating this process by providing dissolved organic carbon. Samples from well CT-EW 133 appear to have excess nitrogen gas, but dissolved oxygen concentrations were $9.0 \mathrm{mg} / \mathrm{L}$, indicating that it is less likely that the excess nitrogen gas originates from denitrification. These results indicate that denitrification occurs at some locations in this aquifer, but is not a dominant process. This is consistent with the work done by Clausen and others (1998), who determined that denitrification in ground water was responsible for only about 1 percent of nitrogen losses along a reach of Muddy Brook, a tributary of Broad Brook.

Ground-water samples collected in Broad Brook Basin during April to May 2004 generally contained low concentrations of dissolved phosphorus, with two exceptions. Samples from two wells, CT-EL 145 and CT-EW 143, contained concentrations of dissolved phosphorus of about $0.1 \mathrm{mg} / \mathrm{L}$. Grady and Mullaney (1998) reported that dissolved phosphorus concentrations in shallow ground water generally are not significantly different in developed and undeveloped land. They found that typical concentrations of dissolved phosphorus ranged from 0.005 to $0.01 \mathrm{mg} / \mathrm{L}$. This is presumably because phosphorus tends to sorb to sediments (Harman and others, 1996; Walter and others, 1996) until the sediments are completely saturated. Grady and Mullaney (1998) reported that samples from glacial aquifers derived from arkosic bedrock (similar to the aquifer of Broad Brook Basin) had significantly higher concentrations of orthophosphate than samples from glacial aquifers derived from crystalline, calcareous, or carbonate bedrock, indicating a possible source for slightly higher concentrations of phosphorus in the arkosic rocks. The median concentration reported by Grady and Mullaney (1998) was $0.02 \mathrm{mg} / \mathrm{L}$ of orthophosphate as phosphorus. Sample concentrations larger than $0.02 \mathrm{mg} / \mathrm{L}$ may indicate some enrichment of phosphorus above what would be expected for glacial stratified deposits from arkosic bedrock.

\section{Ground-Water Age}

Ground-water samples were collected from selected wells to analyze and interpret ground-water ages using $\mathrm{SF}_{6},{ }^{3} \mathrm{H} /{ }^{3} \mathrm{He}$, and ${ }^{3} \mathrm{H}$ (table 2). The apparent ages were used to constrain travel times in the MODFLOW/MODPATH simulations and for understanding the age distribution of ground water in the glacial stratified aquifer. Apparent ground-water ages for samples collected from April to May 2004 ranged from 2.4 years to greater than 50 years. The oldest ground-water samples were collected from wells CT-EL 145 and 146 (89 and $40.2 \mathrm{ft}$ deep, respectively) in the center of the basin in an area with the thickest glacial stratified deposits. The youngest ground-water samples generally were collected from wells screened near the water table.

There was some difficulty in interpreting the ground-water ages due to several factors. For example, a number of the wells that were sampled for ${ }^{3} \mathrm{H} /{ }^{3} \mathrm{He}$ analysis had an excess of terrigenic Helium-4 $\left({ }^{4} \mathrm{He}\right)$. Terrigenic helium is derived from the earth's mantle or from bedrock. Excess ${ }^{4} \mathrm{He}$ will cause a young bias in the ground-water age. In several cases when this excess was minimal, corrections were made to the data to account for this extra source. When the excess is large, data are needed on the crustal abundance of ${ }^{4} \mathrm{He}$ in local surficial materials and bedrock to correct the apparent age. In two cases with excess terrigenic ${ }^{4} \mathrm{He}$, concentrations of tritium were very low, indicating it was old water that originated prior to the peak of nuclearweapons testing in the mid-1960's.

Samples from wells CT-EL 145 and CT-EL 146 likely contain older water that originated as recharge prior to the peak of nuclear-weapons testing in 1964 . Although ${ }^{3} \mathrm{H} /{ }^{3} \mathrm{He}$ ages could not be calculated (due to excess terrigenic ${ }^{4} \mathrm{He}$ and water too old to date by this method), tritium concentrations were 0.57 and $0.14 \mathrm{TU}$, respectively, indicating these waters date to before 1954. These same two samples also contained $\mathrm{SF}_{6}$ at concentrations of 1.2 to 1.8 part per trillion by volume (pptv). This corresponds to a recharge date of 1983 to 1987, based on the input function for $\mathrm{SF}_{6}$ (fig. 4).

In general, the ages determined using $\mathrm{SF}_{6}$ interpretation were younger than those determined by interpretation of ${ }^{3} \mathrm{H}$ and ${ }^{3} \mathrm{He}$. Reasons for this discrepancy may include a natural source of $\mathrm{SF}_{6}$ (Busenberg and Plummer, 2000), an input of $\mathrm{SF}_{6}$ that differs from the input function (fig. 3) that was used in the age calculation, or mixing of younger and older waters. Mixing models for tracers in ground water have been developed by Bohlke (2006). Data for $\mathrm{SF}_{6}$ and ${ }^{3} \mathrm{H}$ plot near a line that suggests binary mixing of older and younger waters (fig. 7), however, it is unlikely that there is mixing of very young water $(\sim 3$ yr) with older water at the location of wells CT-EL 145 and 
Table 1. Water-quality data for samples from selected wells Broad Brook Basin, north-central Connecticut, 2004.

[LSD, land-surface datum; mm Hg, millimeters of mercury; mg/L, milligrams per liter; $\mu \mathrm{S} / \mathrm{cm}$, microsiemens per centimeter; degrees $\mathrm{C}$, degrees Celsius; $\mathrm{N}$, nitrogen; $\mathrm{P}$, phosphorus; <, less than; E, estimated value; --, not available]

\begin{tabular}{|c|c|c|c|c|c|c|c|c|c|c|}
\hline $\begin{array}{l}\text { Local well } \\
\text { identifier }\end{array}$ & Station number & Date & Time & $\begin{array}{l}\text { Depth } \\
\text { of well, } \\
\text { in feet } \\
\text { below } \\
\text { LSD }\end{array}$ & $\begin{array}{l}\text { Depth } \\
\text { to water } \\
\text { level, } \\
\text { in feet } \\
\text { below } \\
\text { LSD }\end{array}$ & $\begin{array}{l}\text { Alti- } \\
\text { tude of } \\
\text { land } \\
\text { surface, } \\
\text { in feet }\end{array}$ & $\begin{array}{c}\text { Baro- } \\
\text { metric } \\
\text { pres- } \\
\text { sure, in } \\
\mathrm{mm} \mathrm{Hg}\end{array}$ & $\begin{array}{c}\text { Dis- } \\
\text { solved } \\
\text { oxygen, } \\
\text { in } \mathrm{mg} / \mathrm{L}\end{array}$ & $\begin{array}{c}\text { Dis- } \\
\text { solved } \\
\text { oxygen, } \\
\text { percent } \\
\text { of sat- } \\
\text { uration }\end{array}$ & $\begin{array}{c}\mathrm{pH}, \\
\text { water, } \\
\text { unfiltered } \\
\text { field, in } \\
\text { standard } \\
\text { units }\end{array}$ \\
\hline CT-EL 82 & 415458072291901 & $04-29-04$ & 1430 & 24.50 & 5.32 & 193 & 770 & 8.3 & 81 & 8.1 \\
\hline CT-EL 142 & 415542072273601 & $05-07-04$ & 1015 & 37.54 & 16.15 & 250 & 754 & 10.9 & 104 & 6.2 \\
\hline CT-EL 143 & 415442072274601 & $05-05-04$ & 1045 & 41.4 & 11.96 & 230 & 756 & 1.0 & 10 & 6.5 \\
\hline CT-EL 144 & 415442072274602 & $05-05-04$ & 1330 & 24 & 14.96 & 230 & 756 & .1 & 1 & 5.7 \\
\hline CT-EL 145 & 415450072290901 & 04-29-04 & 1200 & 89 & 7.62 & 205 & 770 & 8.1 & 73 & 8.4 \\
\hline CT-EL 146 & 415450072290902 & $04-28-04$ & 1345 & 40.2 & 8.73 & 205 & 753 & 8.4 & 78 & 7.8 \\
\hline CT-EL 147 & 415450072290903 & $04-28-04$ & 1030 & 20 & 8.50 & 205 & 753 & 4.7 & 41 & 5.6 \\
\hline CT-EW 133 & 415450072332201 & $05-11-04$ & 1200 & 22.6 & 4.48 & 40 & -- & 9.0 & -- & 7.8 \\
\hline CT-EW 134 & 415548072311301 & $05-10-04$ & 1200 & 102 & 49.80 & 185 & 762 & 7.9 & 78 & 7.8 \\
\hline CT-EW 142 & 415552072311601 & 05-04-04 & 1100 & 35.9 & 2.05 & 130 & 755 & 6.1 & 56 & 6.4 \\
\hline CT-EW 143 & 415552072311602 & 05-04-04 & 1340 & 18.7 & 1.65 & 130 & 755 & 4.8 & 43 & 6.4 \\
\hline
\end{tabular}

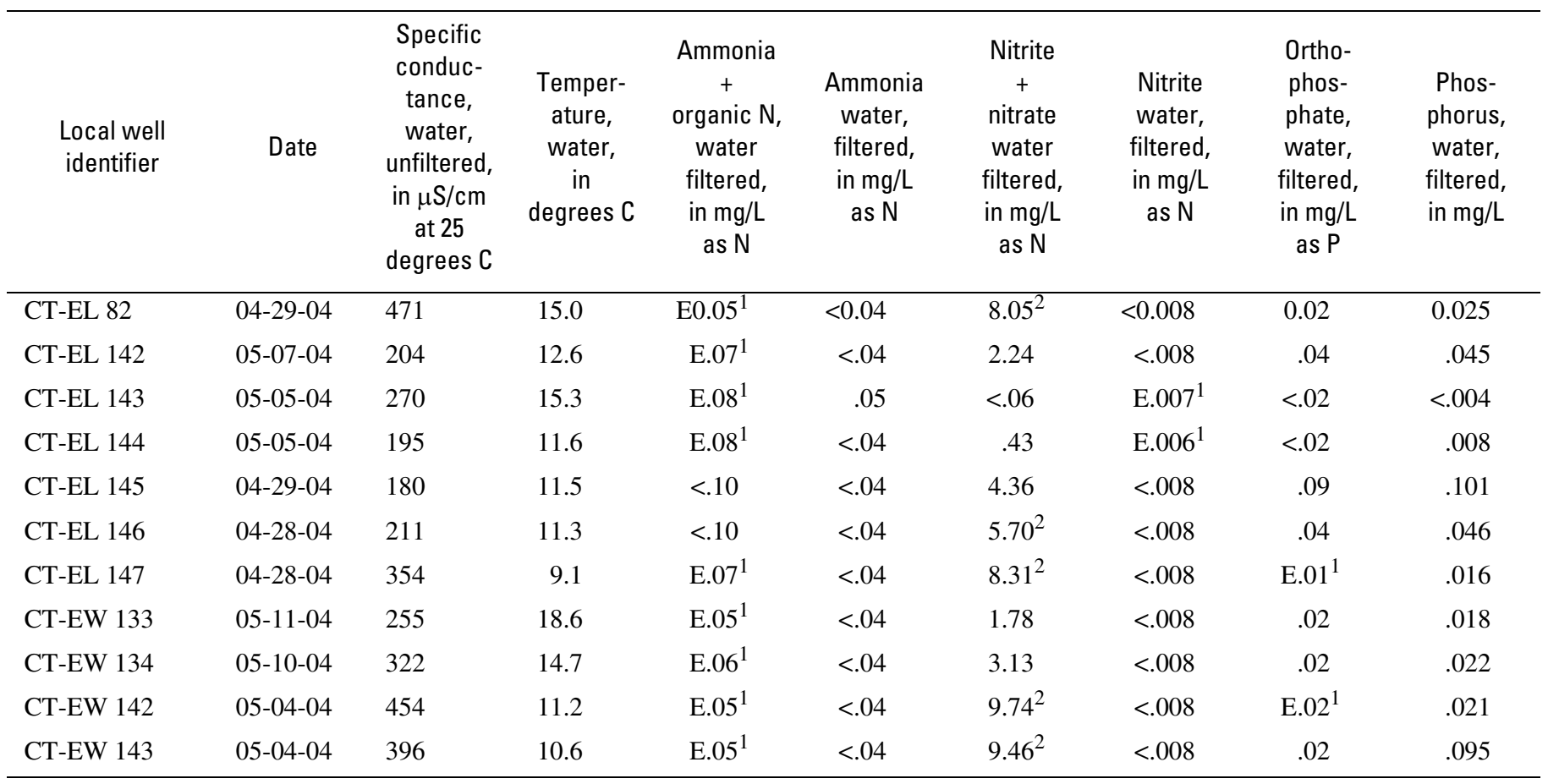

${ }^{1}$ Below the laboratory reporting limit and above the long-term method detection limit.

${ }^{2}$ Diluted sample method high range exceeded. 
Table 2. Concentrations of sulfur hexafluoride and tritium and apparent ages of ground-water samples in Broad Brook Basin, north-central Connecticut.

$\left[\mathrm{SF}_{6}\right.$, sulfur hexafluoride; pptv, parts per trillion by volume; ${ }^{3} \mathrm{H} /{ }^{3} \mathrm{He}$, tritium/helium-3; TU, tritium units, multiple listing of the same station indicates dupicate samples; >, greater than; --, not available]

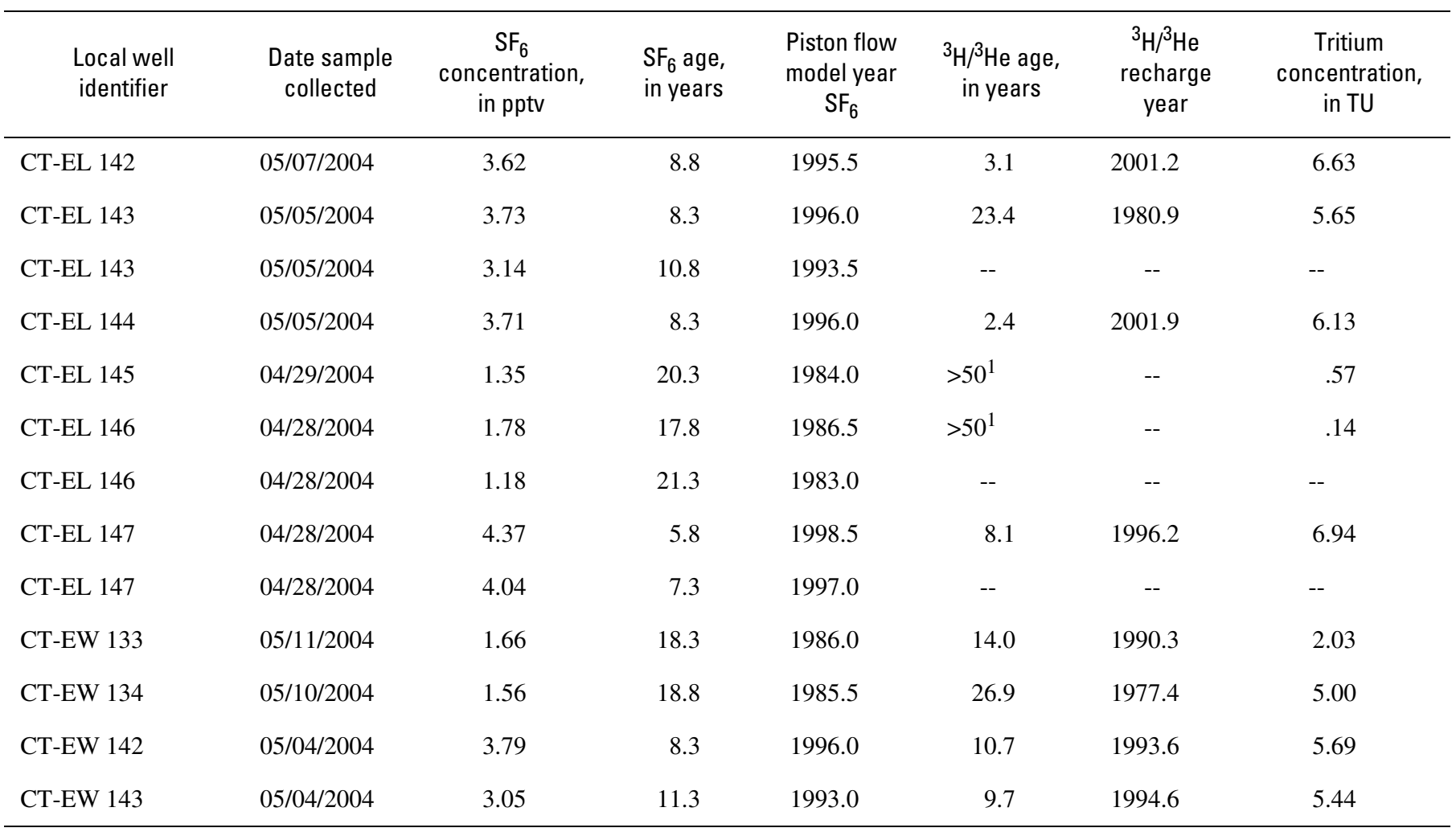

\footnotetext{
${ }^{1}$ Estimate based on tritium concentrations.
} 


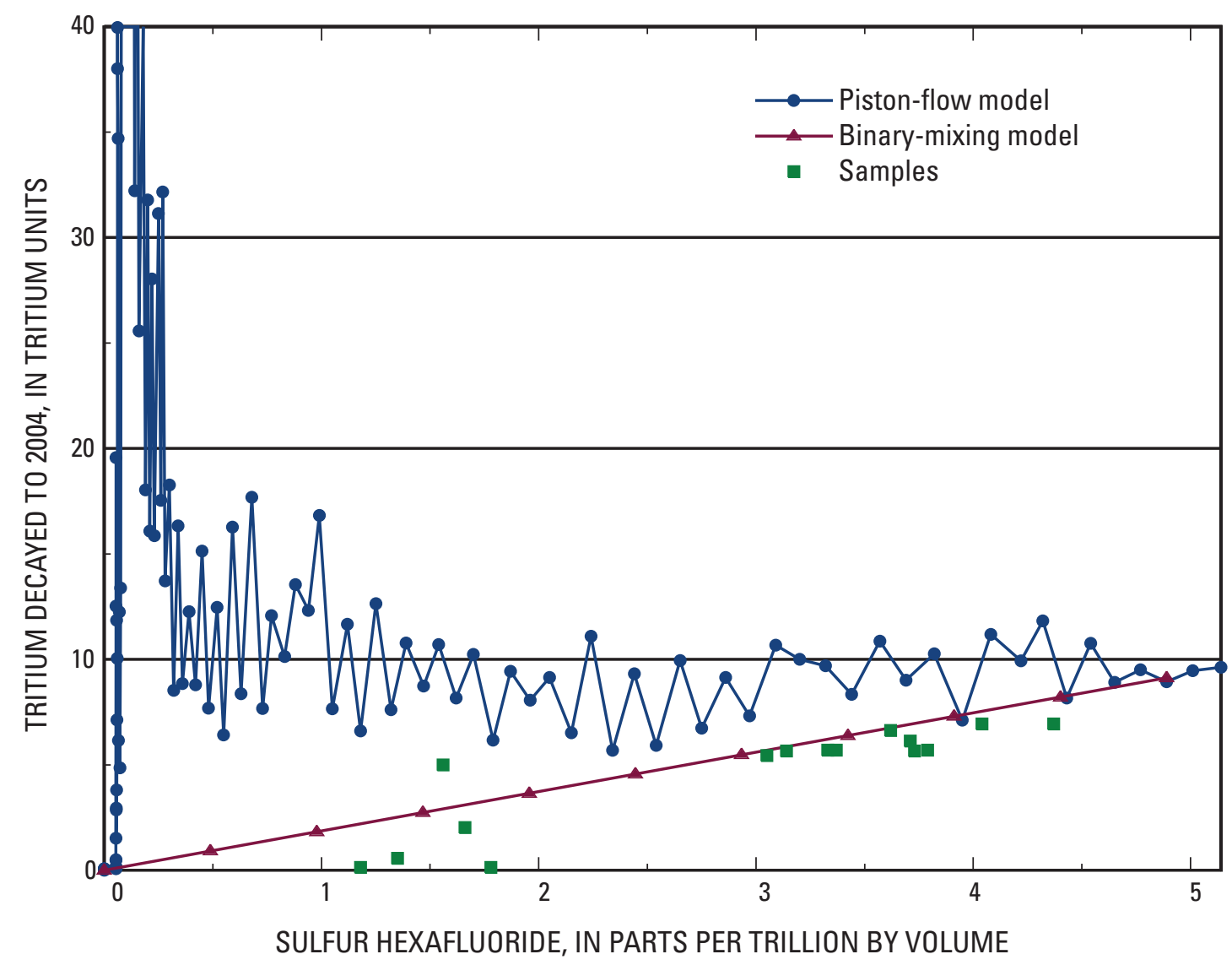

Figure 7. Relation between concentrations of sulfur hexafluoride and tritium and mixing models for younger (2001) and older pre-tracer water in Broad Brook Basin, north-central Connecticut. (Tritium input from R.L. Michel, U.S. Geological Survey, written commun., 2005.)

CT-EL 146. These wells are in unconsolidated fine-grained glacial stratified deposits in the middle of the thickest part of the aquifer. Previous investigations (Lindsey and others, 2003) indicate that mixing is more likely in bedrock aquifers or wells penetrating multiple fractures in bedrock aquifers, in discharge from springs, or in areas where ground-water withdrawals have caused mixing of shallow and deep zones. Mixing also could occur due to converging flow paths near a surface-water body; well-construction characteristics, such as mixing in the annulus of disturbed area around the monitoring well; or mixing of waters in the well-screen zone. Wells sampled for this study had short screens, all less than $5 \mathrm{ft}$.

A likely explanation for the discrepancies between the $\mathrm{SF}_{6}$ and the tritium/helium values is that there is a natural source of $\mathrm{SF}_{6}$, and it is evident only in samples with the oldest water. In wells CT-EL 145 and CT-EL 146, the younger $\mathrm{SF}_{6}$ ages are likely due to a natural source of $\mathrm{SF}_{6}$, because the tritium values are definitive of a large component of pre-nuclear testing recharge water.

\section{Nutrient Loads from Broad Brook Basin}

Nutrient loads were estimated for USGS station 01184490 (Broad Brook at Broad Brook, Connecticut) for water years 1993-2004. The constituents analyzed included total nitrogen, nitrite plus nitrate nitrogen, nitrate nitrogen, total ammonia plus organic nitrogen, total phosphorus, and dissolved phosphorus. An analysis of the relations between sample collection and streamflow indicated that samples were collected over the range of streamflows that occurred during 1993-2004 (fig. 8).

Load estimates were made for base flow to indicate the ground-water contribution of nitrogen to Broad Brook. The analysis of nitrogen loading from base flow was limited to dissolved nitrate nitrogen, as this is likely the dominant nitrogen species in ground water. The load of dissolved phosphorus from base flow also was determined. Instantaneous loads of nitrogen were calculated for subbasins sampled in September 2002. These loads were used to determine parts of the basin contributing the largest loads from ground water. 


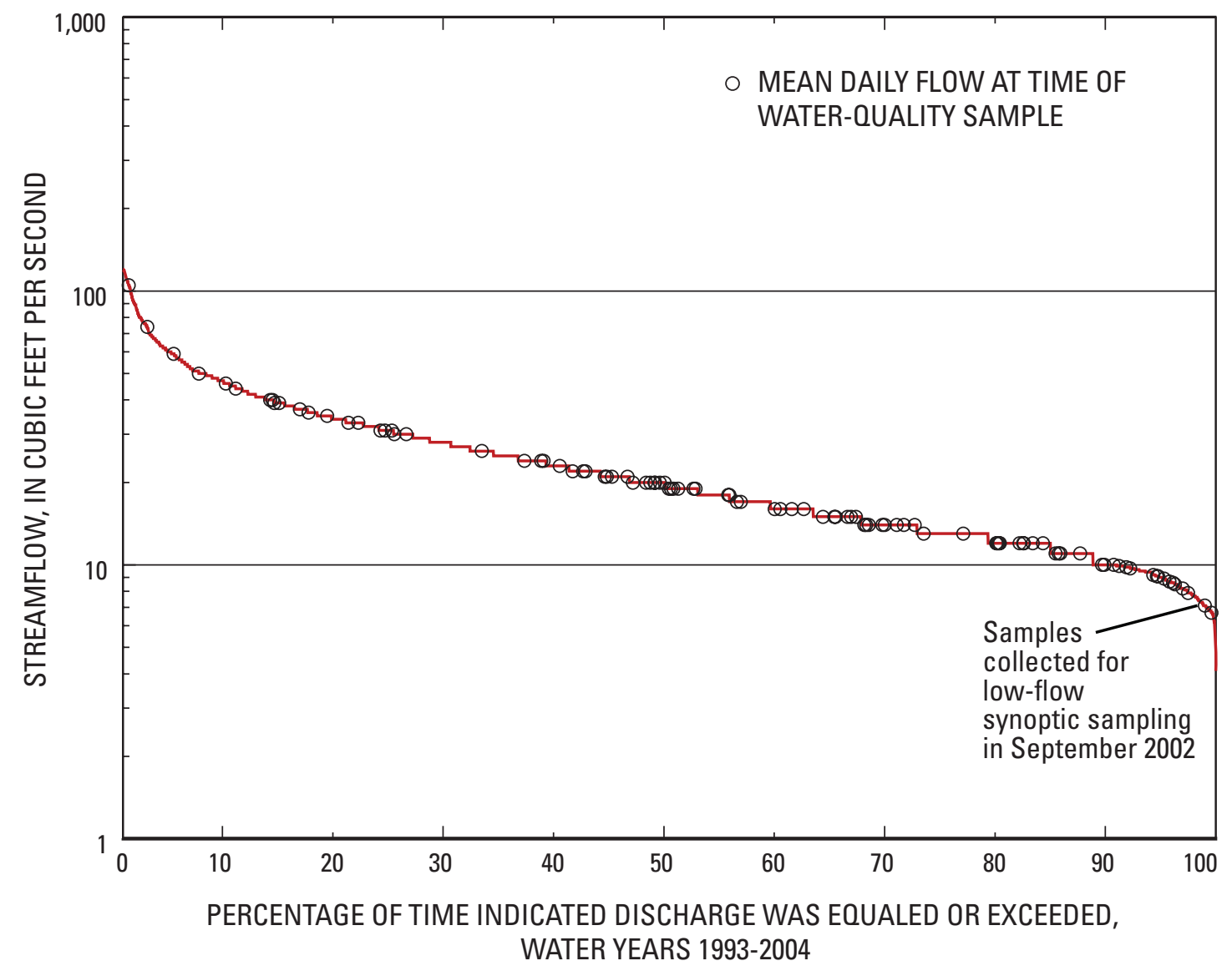

Figure 8. Flow-duration curve and discharge conditions during sampling at Broad Brook at Broad Brook, Connecticut, water years 1993-2004.

\section{Nitrogen}

Total nitrogen loads (appendix 2, fig. 9) at USGS station 01184490, on Broad Brook ranged from 117,000 lb in water year 2002 (a dry year; see fig. 5) to 270,000 lb in water year 1997 (a wet year; see fig. 5). This nitrogen load was dominated by nitrate nitrogen (fig. 9), which averaged 80 percent of the total nitrogen load in water years 1993-2004 (appendix 2).

Total ammonia plus organic nitrogen (fig. 9) averaged about 18 percent of the total nitrogen load. There were no apparent trends in concentration with time of any of the nitrogen species. This was determined by the insignificance of the "time" variable in the ESTIMATOR multiple-linear regression equations. The variables related to seasonality and flow generally were significant for most nitrogen and phosphorus constituents.

Concentrations of total nitrogen in samples from Broad Brook exceeded the USEPA Ecoregion XIV recommended nutrient criteria for nitrogen for rivers and streams $(0.7 \mathrm{mg} / \mathrm{L}$; U.S. Environmental Protection Agency, 2000) in all samples collected during water years 1993-2004. Concentrations of total nitrogen differed by season; concentrations were generally high from September to February and lower from April through August (fig. 10). Differences in concentration can be attributed to seasonal assimilation of nitrogen in streams caused by biological uptake and to seasonal differences in streamflow. Samples collected in March (fig. 10) had some of the lowest concentrations because of dilution effects during periods of high flow. March samples also can have the highest concentrations if a runoff event occurs after the application of manure to fields (Mullaney and Zimmerman, 1997).

Total nitrogen yields from Broad Brook Basin at station 01184490 averaged about 14,000 pounds per square mile per year $\left(\mathrm{lb} / \mathrm{mi}^{2} / \mathrm{yr}\right)$ and are among the largest yields measured in Connecticut (Mullaney and others, 2002). Nitrogen yields at station 01184490 were about 10 times higher than those reported for mostly forested basins (Mullaney and others, 2002; Trench, 2000). 


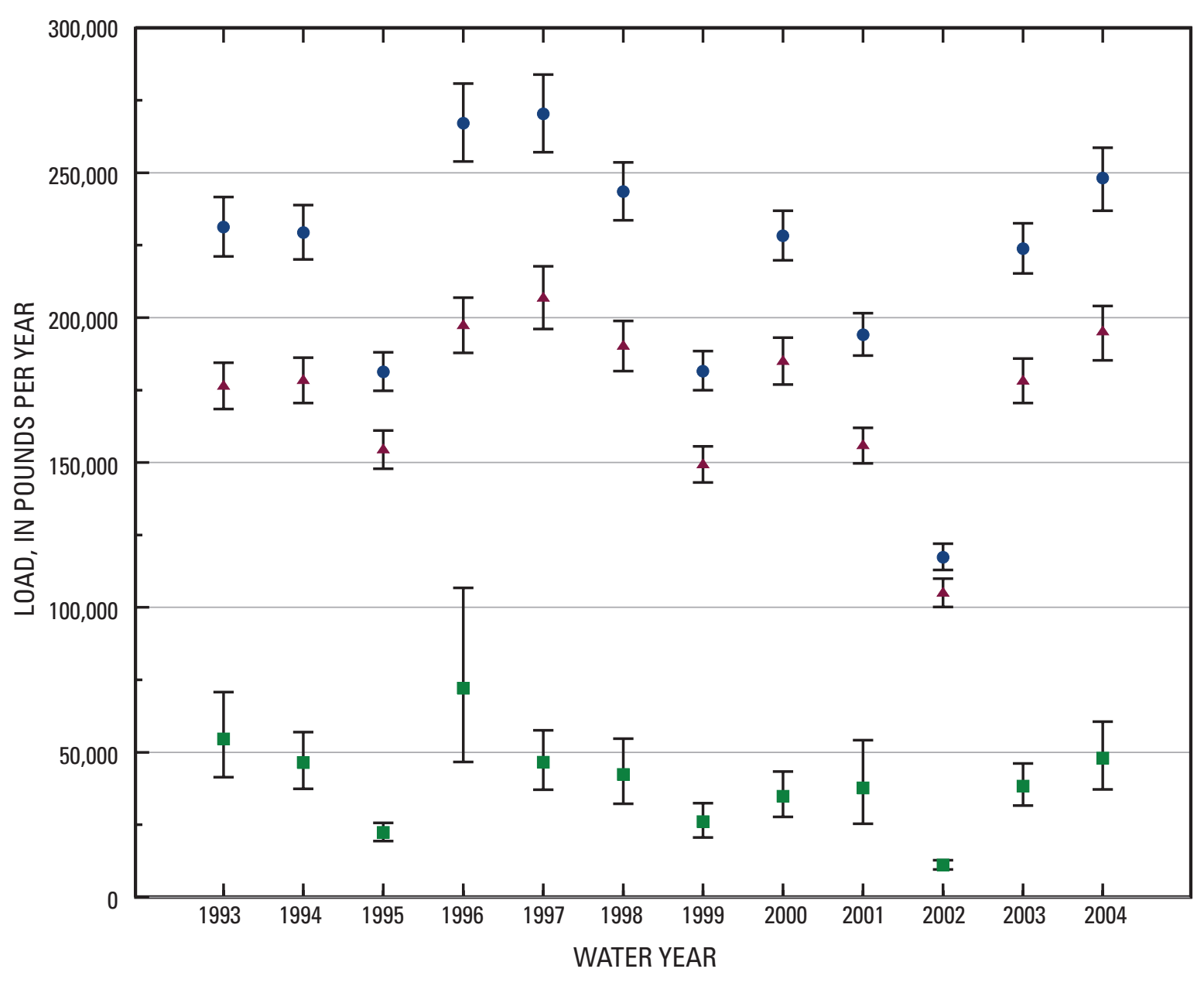

\section{EXPLANATION}

- Total nitrogen

- Nitrate nitrogen

- Total ammonia plus organic nitrogen

Figure 9. Nitrogen loads at U.S. Geological Survey station 01184490, Broad Brook at Broad Brook, Connecticut, for total nitrogen, nitrate nitrogen, and total ammonia plus organic nitrogen. Bars indicate the 95-percent confidence interval. 


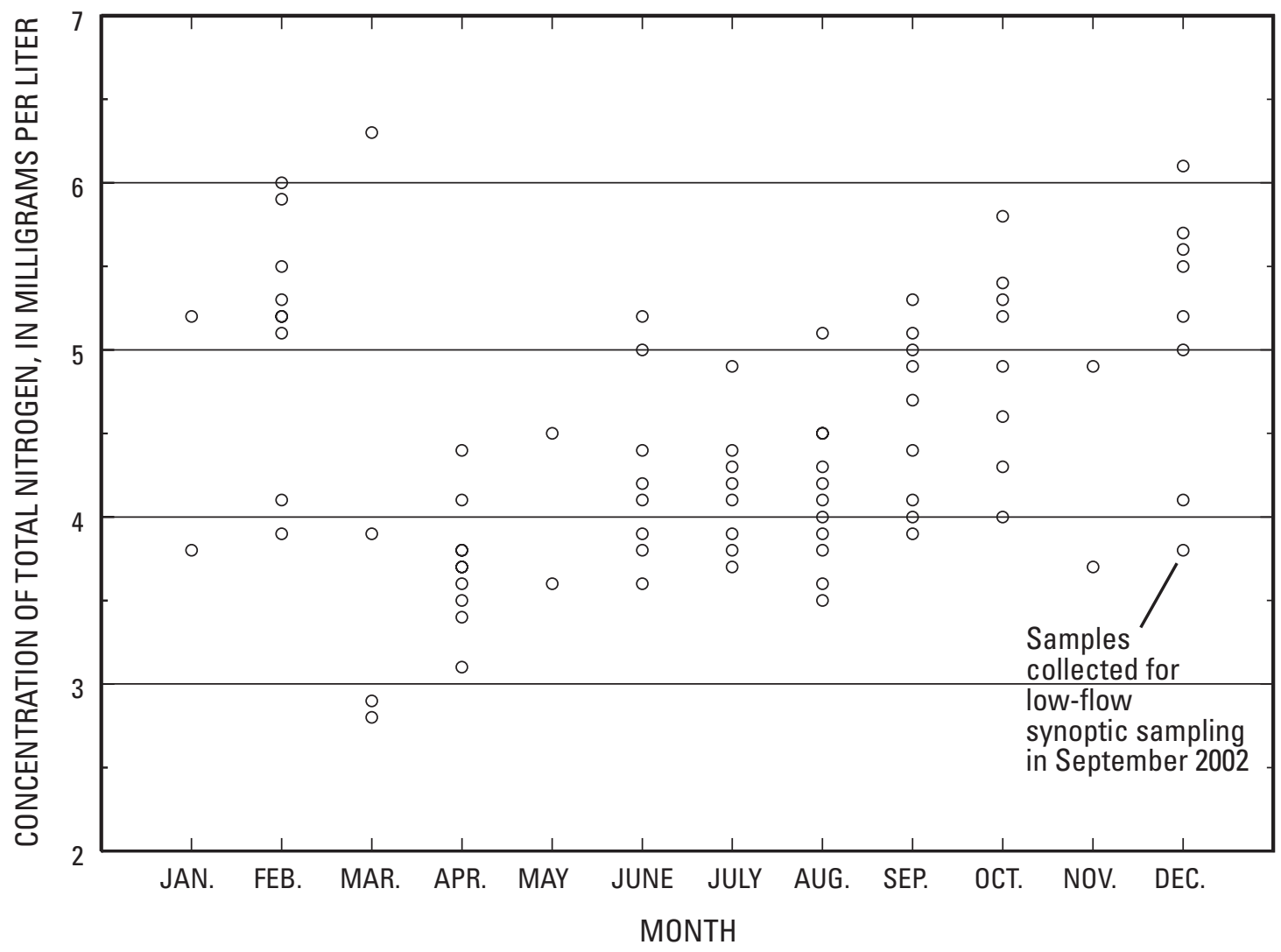

Figure 10. Concentrations of total nitrogen by month at U.S. Geological Survey station 01184490, Broad Brook at Broad Brook, Connecticut, water years 1993-2004. 


\section{Phosphorus}

Total phosphorus loads at USGS station 01184490 on Broad Brook ranged from 2,330 lb in water year 2002 to 14,400 $\mathrm{lb}$ in water year 1996 (appendix 2, fig. 11A) and averaged 8,240 lb. Dissolved phosphorus (fig. 11B) averaged about 71 percent of the annual load of total phosphorus. Total phosphorus yields averaged about $530 \mathrm{lb} / \mathrm{mi}^{2} / \mathrm{yr}$. This yield is more than five times higher than yields reported for forested basins (less than 100 $\mathrm{lb} / \mathrm{mi}^{2} / \mathrm{yr}$ ) by Trench (2000). Concentrations of total phosphorus ranged from 0.02 to $0.63 \mathrm{mg} / \mathrm{L}$ during water years 1993 2004 (table 3). Of 102 samples collected from station 01184490 during the study period, 99 samples had concentrations higher than the USEPA Ecoregion XIV recommended nutrient criteria for phosphorus for rivers and streams $(0.031 \mathrm{mg} / \mathrm{L}$; U.S. Environmental Protection Agency, 2000).

\section{Base-Flow Loads}

Base-flow loads of nitrate nitrogen and dissolved phosphorus were calculated as a means of determining the input of these nutrients from ground-water discharge to Broad Brook. Baseflow loads of nitrate nitrogen ranged from $88,700 \mathrm{lb}$ in water year 2002 to 190,000 lb in water year 1997 (appendix 2, fig. 12A). The base-flow load of nitrate nitrogen from 1993-2004 represents, on average, about 71 percent of the total load of nitrogen, indicating that ground-water discharge to Broad Brook is likely the largest source of nitrogen on an annual basis (fig.13). The estimates of base-flow loads of nitrate nitrogen likely include the effects of instream loss of nitrogen due to biological processing, or denitrification. Base-flow loads may also include some nitrate from the mineralization of ammonia and organic nitrogen deposited in the streambed during storm events. This load has been considered to be insignificant in this analysis.

Base-flow loads of dissolved phosphorus ranged from 980 $\mathrm{lb}$ in water year 2002 to 3,000 lb in 1997 (appendix 2, fig.12B). Phosphorus loads delivered to Broad Brook during base flow are less likely than nitrate loads to originate from ground-water discharge. Grady and Mullaney (1998) determined that concentrations of dissolved phosphorus generally are very low in ground water beneath agricultural land. The sources of dissolved phosphorus in base flow probably include some groundwater input, plus phosphorus released from bottom sediments in impoundments, such as Broad Brook Millpond. The base-flow load of dissolved phosphorus averages about 40 percent of the annual load of dissolved phosphorus, indicating that the majority (60 percent) of the dissolved phosphorus load is delivered to Broad Brook during storm events.

Table 3. Concentrations, loads, and yields of nitrogen and phosphorus at U.S. Geological Survey station 01184490, Broad Brook at Broad Brook, Connecticut, 1993-2004.

\begin{tabular}{|c|c|c|c|c|c|c|}
\hline \multirow[b]{2}{*}{ Constituent } & \multicolumn{4}{|c|}{ Concentration, in milligrams per liter } & \multirow[b]{2}{*}{$\begin{array}{l}\text { Mean load, } \\
\text { in pounds per year }\end{array}$} & \multirow{2}{*}{$\begin{array}{l}\text { Mean yield, } \\
\text { in pounds per } \\
\text { square mile } \\
\text { per year }\end{array}$} \\
\hline & Minimum & Median & Maximum & $\begin{array}{l}\text { Recommended } \\
\text { nutrient } \\
\text { criteria }^{1}\end{array}$ & & \\
\hline Total nitrogen & 2.8 & 4.2 & 6.3 & 0.7 & 218,000 & 14,100 \\
\hline $\begin{array}{l}\text { Nitrite plus nitrate } \\
\text { nitrogen }\end{array}$ & 1.3 & 3.7 & 5.8 & & 175,000 & 11,300 \\
\hline Nitrate nitrogen & 1.3 & 3.7 & 5.8 & & 173,000 & 11,100 \\
\hline $\begin{array}{l}\text { Total ammonia plus } \\
\text { organic nitrogen }\end{array}$ & .14 & .43 & 4.2 & & 40,100 & 2,580 \\
\hline Total phosphorus & .02 & .08 & .63 & .031 & 8,240 & 531 \\
\hline Dissolved phosphorus & .019 & .05 & .49 & & 5,830 & 376 \\
\hline
\end{tabular}

\footnotetext{
${ }^{1}$ U.S. Environmental Protection Agency (2000).
} 

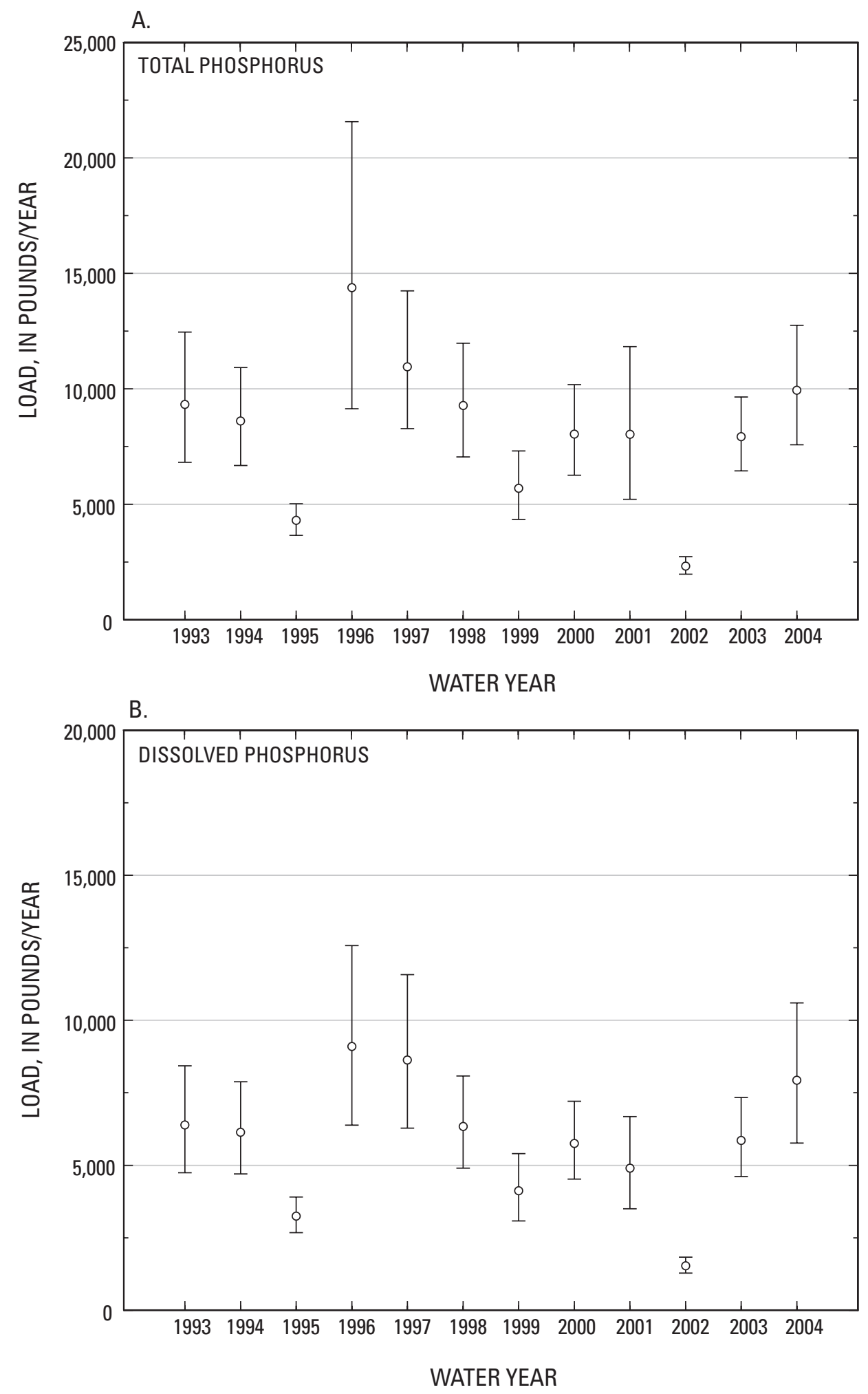

Figure 11. Phosphorus loads at U.S. Geological Survey station 01184490, Broad Brook at Broad Brook, Connecticut, for (A) total phosphorus, and (B) dissolved phosphorus. Bars indicate the 95percent confidence interval. 

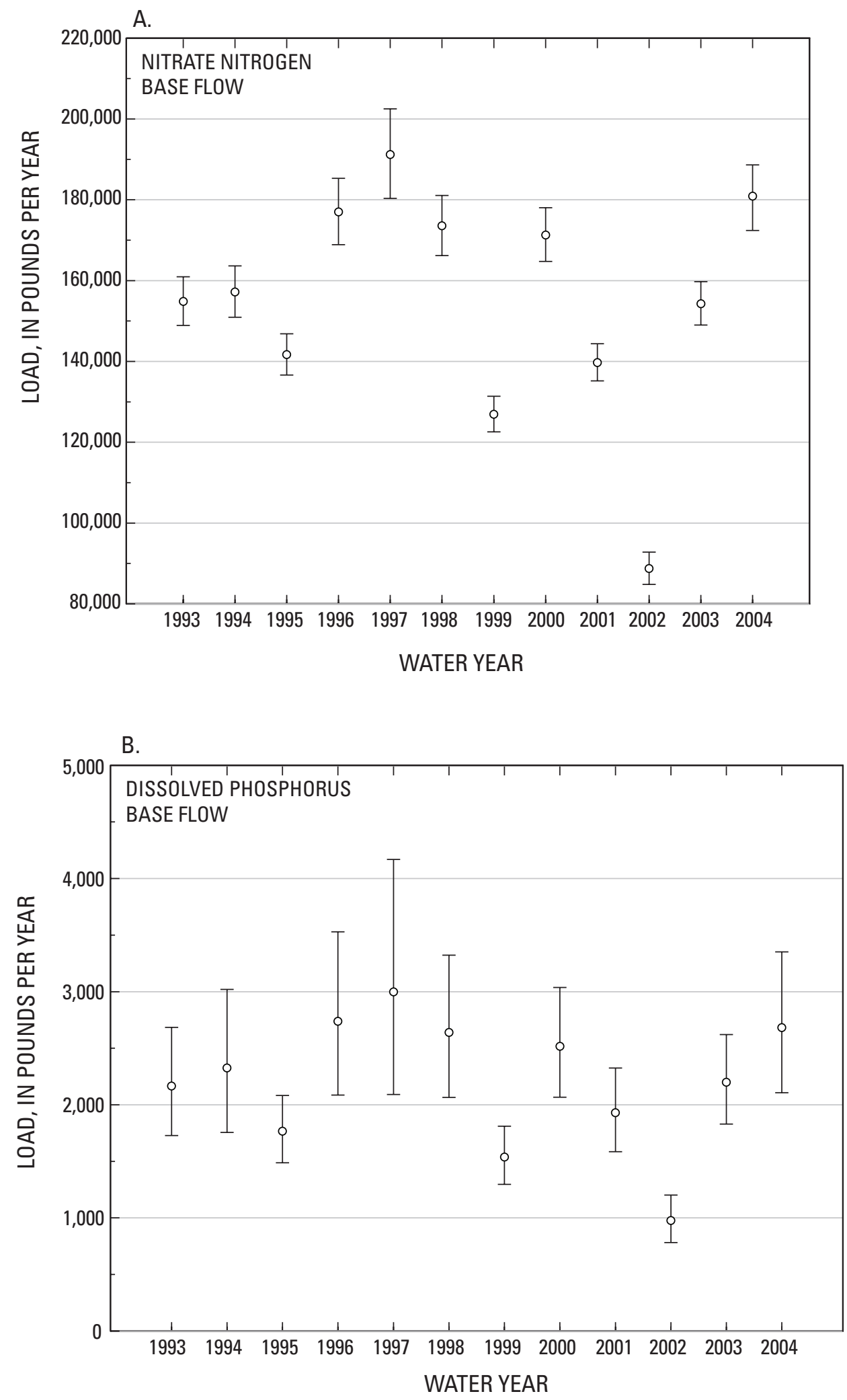

Figure 12. Base-flow loads at U.S. Geological Survey station 01184490, Broad Brook at Broad Brook, Connecticut, for (A) nitrate nitrogen and (B) dissolved phosphorus. 


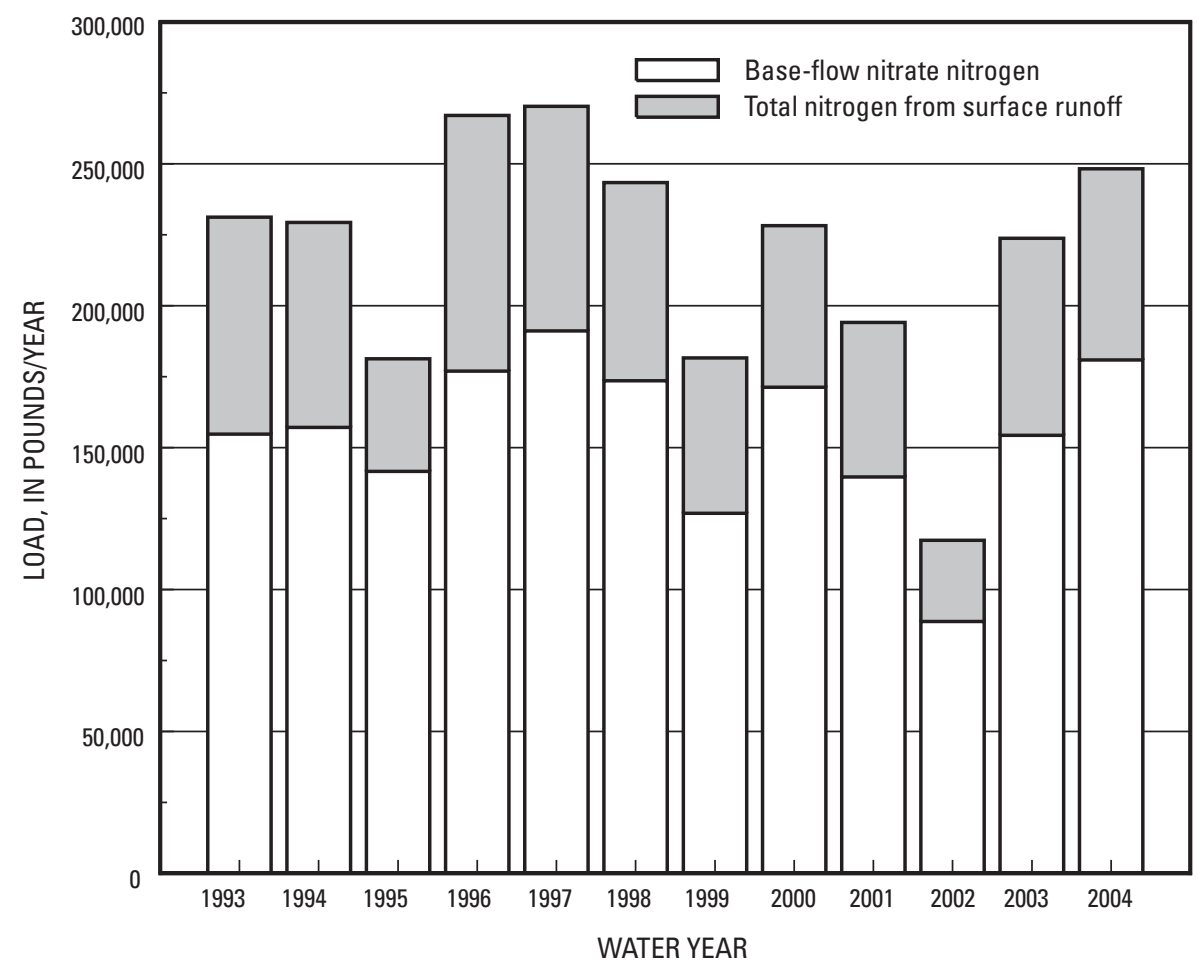

Figure 13. Base-flow loads of nitrate nitrogen and total nitrogen loads from surface runoff at U.S. Geological Survey station 01184490, Broad Brook at Broad Brook, Connecticut.

Water-quality samples and measurements of stream discharge were collected at 11 sites in Broad Brook Basin from September 18-20, 2002 during low-flow conditions to understand the contribution of nutrients to the mouth of the basin from the headwaters. Instantaneous loads of nitrogen and phosphorus were calculated for each stream reach, which were then used to determine the load for each subbasin by subtracting upstream loads (figs. 14-16). The instantaneous load of total nitrogen at USGS station 01184490 on September 19, 2002 was equivalent to 150 pounds per day (lb/d), an amount much lower than the average daily load for 1993-2004 of about $600 \mathrm{lb}$. The combined nitrogen load from two upstream basins with the largest contributions totaled about $138 \mathrm{lb}$ from an area that measures $3.7 \mathrm{mi}^{2}$ or 23.9 percent of the drainage area of USGS station $01184490\left(15.5 \mathrm{mi}^{2}\right)$. The loads at most of the subbasin sampling sites are dominated by nitrate nitrogen (about 88 percent).

Loads at USGS station 01184470 (Broad Brook at Melrose, Connecticut) were larger than the loads at downstream USGS station (01184490), indicating a loss of nitrogen in the lower reaches of Broad Brook Basin. This loss of nitrogen may be due to assimilation by aquatic life, temporary storage (described below), or denitrification in Broad Brook Millpond.
Water-quality data collected at USGS station 01184490 show that nitrogen concentrations typically are highest during the non-growing season, indicating some storage of nitrogen in algae and aquatic plants during the growing season. This nitrogen may be returned to the system when the biomass decomposes and is carried downstream by high streamflows during the fall. The quality of ground-water discharge may be better represented by concentrations of nitrate nitrogen in base flow during the non-growing season than by concentrations during the growing season.

The instantaneous load of total phosphorus at station 01184490 on September 19, 2002 was equivalent to $2 \mathrm{lb} / \mathrm{d}$. The average daily load of total phosphorus at station 01184490 was about $23 \mathrm{lb} / \mathrm{d}$ during water years 1993-2004. The subbasins with the highest load of total phosphorus during this low-flow condition contributed about 0.1 to $0.5 \mathrm{lb} / \mathrm{d}$ (fig. 16). The subbasins (sampled September 18-19, 2002) with the largest contributions of phosphorus contain impoundments (fig. 16), indicating that some phosphorus may be released from sediment deposited in these impoundments during times when low dissolved oxygen conditions exist; the remainder of the phosphorus probably originates from ground-water discharge to the streams in the basin. 


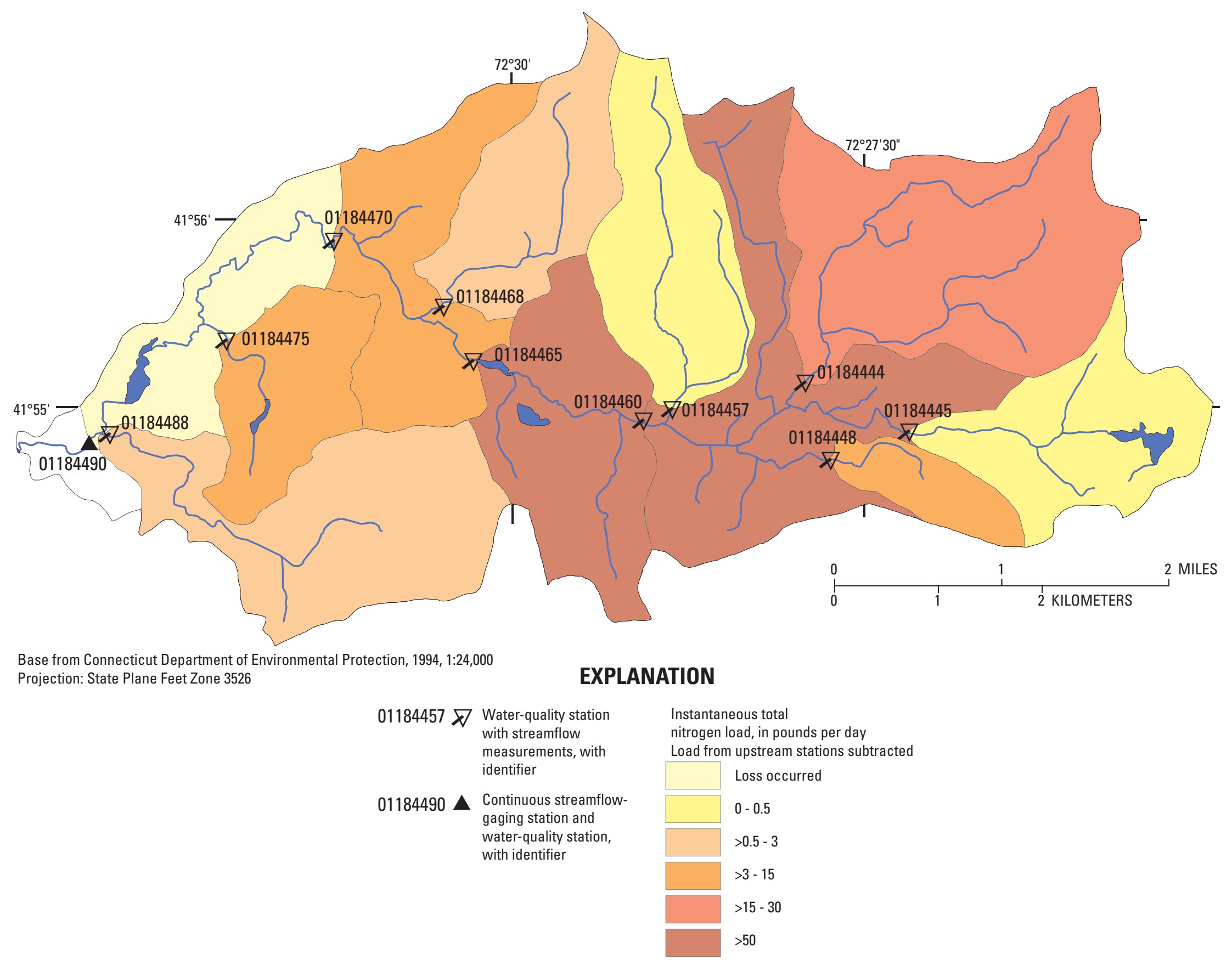

Figure 14. Base-flow loads of total nitrogen from selected subbasins, September 18-20, 2002, Broad Brook Basin, north-central Connecticut. 


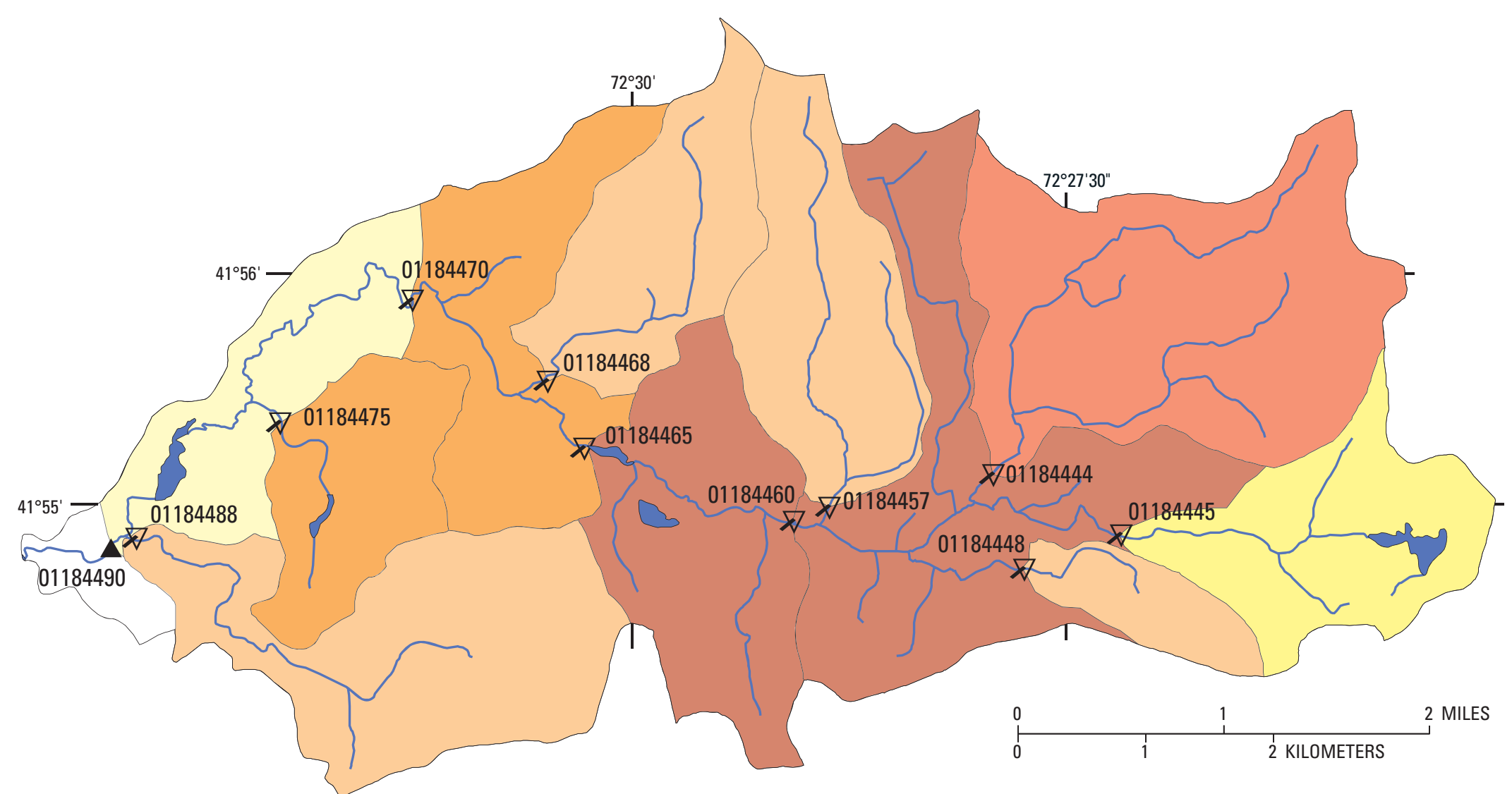

Base from Connecticut Department of Environmental Protection, 1994, 1:24,000 Projection: State Plane Feet Zone 3526

\section{EXPLANATION}

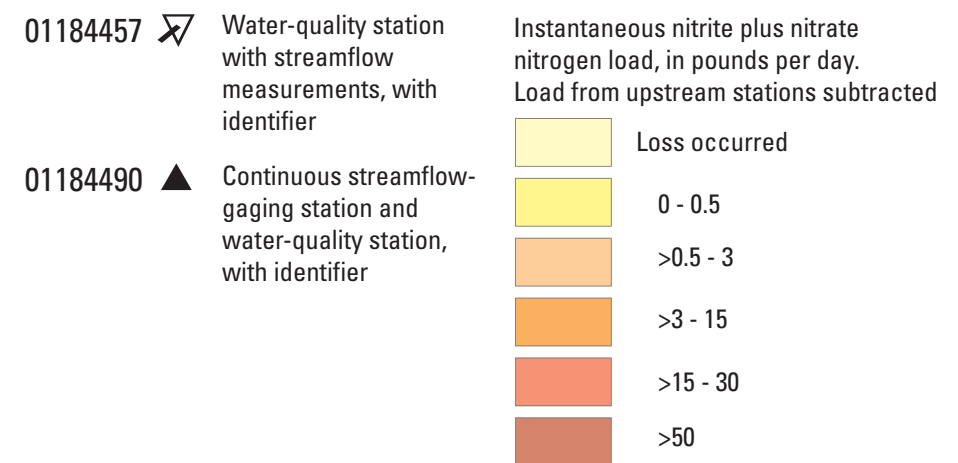

Figure 15. Base-flow loads of nitrite plus nitrate nitrogen from selected subbasins, September 18-20, 2002, Broad Brook Basin, north-central Connecticut. 


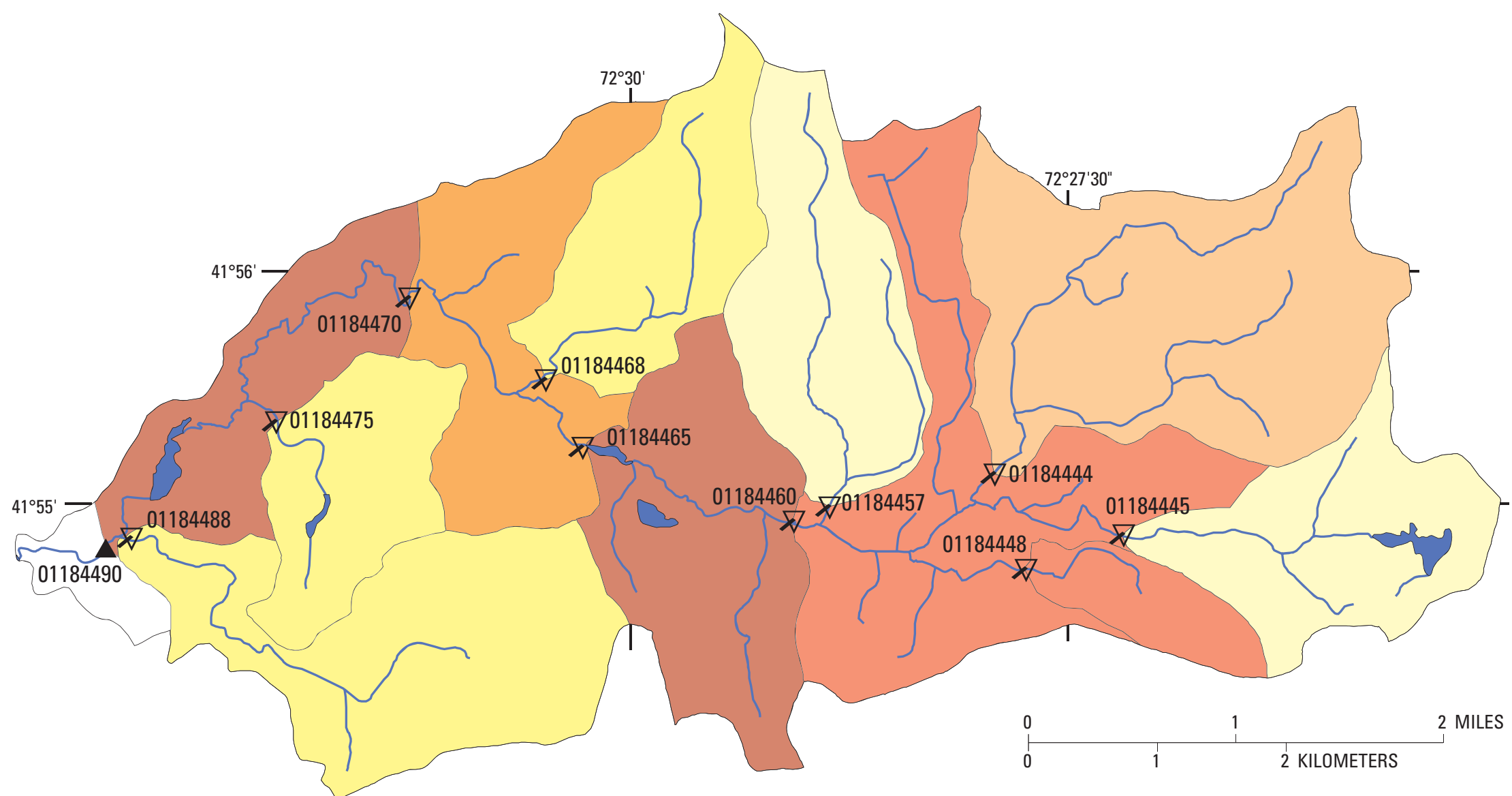

Base from Connecticut Department of Environmental Protection, 1994, 1:24,000 Projection: State Plane Feet Zone 3526

\section{EXPLANATION}

\begin{tabular}{|c|c|c|}
\hline \multirow[t]{2}{*}{$01184457 \varnothing$} & \multirow{2}{*}{$\begin{array}{l}\text { Water-quality station } \\
\text { with streamflow } \\
\text { measurements, with } \\
\text { identifier }\end{array}$} & $\begin{array}{l}\text { Instantaneous total } \\
\text { phosphorus load, in pound } \\
\text { Load from upstream statio }\end{array}$ \\
\hline & & $0-0.01$ \\
\hline \multirow[t]{5}{*}{$01184490 \Delta$} & $\begin{array}{l}\text { Continuous streamflow- } \\
\text { gaging station and }\end{array}$ & $>0.01-0.04$ \\
\hline & $\begin{array}{l}\text { water-quality statıon, } \\
\text { with identifier }\end{array}$ & $>0.04-0.07$ \\
\hline & & $>0.07-0.17$ \\
\hline & & $>0.17-0.36$ \\
\hline & & $>0.36$ \\
\hline
\end{tabular}

Figure 16. Base-flow loads of total phosphorus from selected subbasins, September 18-20, 2002, Broad Brook Basin, north-central Connecticut. 


\section{Simulation of Future Nitrogen Loads from Ground Water}

The results of the MODFLOW/MODPATH simulations were used to simulate current and alternative future loads from urban and agricultural land in the watershed. These scenarios were generated by multiplying the recharge rates used in or determined from the MODFLOW steady-state simulation by the assumed concentrations of nitrate nitrogen from different land-use and land-cover types. The simulated output base-flow load of nitrate nitrogen was compared with base-flow load (fig. 12A) calculations. It was assumed that the current input of nitrate nitrogen to the water table is not substantially different from the input at the time of recharge. Future scenarios were generated by applying changes in the concentration of nitrate nitrogen at the water table, applying the simulated travel times from the MODPATH simulations, and generating graphs to show the number years required before improvements would be seen in the water quality at the downstream end of Broad Brook Basin based on ground-water travel times.

\section{Recharge Rates, Nitrate Concentrations, and Loads}

Long-term average recharge rates were assigned to each cell in the ground-water-flow model. Rates varied depending on the dominant surficial geologic material in each cell of the model. The simulated long-term average recharge rate was 24.6 $\mathrm{in} / \mathrm{yr}$ to areas underlain by glacial stratified deposits and 7.9 in/yr to till deposits. (appendix 1).
Concentrations of nitrate nitrogen were assigned to different land uses and land covers on the basis of information from Grady (1994), Grady and Mullaney (1998), and Mullaney and Zimmerman (1997), and from ground-water samples collected for this study. Agricultural areas were assigned values of nitrate concentration higher than median concentrations reported by Grady (1994) and Grady and Mullaney (1998). This was done because Broad Brook Basin was reported by Mullaney and others (2002) to have atypical nitrogen concentrations for an agricultural area. The ground-water quality sampling and base-flow water-quality sampling done for this study confirmed that concentrations of nitrite plus nitrate nitrogen were higher than median values reported previously for agricultural areas in Connecticut.

Recharge rates were multiplied by the estimated concentration of nitrate nitrogen to determine the loading to the water table from each model cell. The concentration values used and the 2002 estimated nitrate load to the water table are shown in table 4. The load of nitrogen to the water table is largest from agricultural land in the basin. The value of $6.5 \mathrm{mg} / \mathrm{L}$ chosen for use is a typical value based on studies in the watershed, but values can be higher or lower depending on the intensity of the agriculture in individual subbasins. The estimated load of nitrogen to the water table using this method was about $154,000 \mathrm{lb}$, which is similar to the average base-flow load of nitrate nitrogen of 154,800 lb estimated for water years 1993-2004 (appendix 2). It is likely that the estimates of base-flow loads of nitrate (appendix 2) include the effects of instream loss of nitrogen; therefore, average concentrations of nitrate nitrogen in groundwater discharge to Broad Brook may be higher than the values in table 4, as shown by the seasonal variation of total nitrogen in Broad Brook (fig. 10).

Table 4. Concentrations of nitrate nitrogen assigned to land-use and land-cover categories, and estimated load to the water table, Broad Brook Basin, north-central Connecticut.

[2002 Land-use/land-cover data modified from Civco and Hurd, 2003]

\begin{tabular}{lcc}
\hline Land-use/land-cover category & $\begin{array}{c}\text { Estimated concentration of } \\
\text { nitrate nitrogen, } \\
\text { in milligrams per liter }\end{array}$ & $\begin{array}{c}\text { Estimated loading to the water table (in } \\
\text { pounds) based on land cover in 2002 and } \\
\text { recharge rates for different geologic materials }\end{array}$ \\
\hline Developed & ${ }^{1} 3.0$ & 14,200 \\
Turf and grass & 21.5 & 470 \\
Other grasses and agriculture & ${ }^{3} 6.5$ & 137,000 \\
Forest and wetland & ${ }^{4} 0.14$ & 1,450 \\
Utility right of way and barren land & ${ }^{5} 1.0$ & 970 \\
Total & 154,090 \\
\hline${ }^{1}$ Median values from Grady (1994) for unsewered residential 2.3 mg/L, sewered residential 2.4 mg/L. It was assumed that concentra- \\
tions under developed land are slightly higher than those reported by Grady (1994), which contained turf and landscaped areas that would \\
have slightly lower nitrate concentrations. \\
${ }^{2}$ Median values from Grady (1994) untilled agriculture (1.5 mg/L) should be similar to areas of turf. \\
${ }^{3}$ Estimated for this study based on ground-water sampling and low-flow sampling (September 2002). \\
${ }^{4}$ Median values from Grady and Mullaney (1998). \\
${ }^{5}$ Estimated.
\end{tabular}


Current Loads from Ground Water to Broad Brook and Age of Ground -Water Discharge

Estimating loads of nitrogen from ground water to Broad Brook is complicated by the different ground-water travel times from different parts of the basin. The concentrations of nitrate nitrogen in ground water reflect land use at the time of recharge. The current load of nitrogen to Broad Brook from ground-water discharge contains water that is a mixture of different ages. The cumulative distribution of the age of base flow to Broad Brook was calculated as follows. Travel times from recharge to discharge in a river cell were calculated for each cell in the model using MODPATH, and these times were paired with the recharge rate assigned to each cell. Water was assumed to pass through weak sinks in the ground-water-flow model. These weak sinks were in cells that contained upland streams. The resulting travel times were sorted, and the cumulative flow was calculated by summing the recharge for all cells having younger travel times (fig. 17). MODPATH was calibrated by adjusting the porosity values in the glacial deposits and bedrock to obtain the best match to measurements of apparent ground-water age (ages shown in appendix 1 (table 1-6; information on porosity in appendix 1).

The simulations in MODPATH indicate that, under longterm average conditions, about 50 percent of the ground water discharged to Broad Brook in 2006 originated as ground-water recharge before 1995 (residence time greater than 11 years), about 18 percent originated before 1980 (residence time greater than 26 years), and about 8 percent originated before 1960 (residence time greater than 46 years) (fig. 17). The remaining 50 percent of the current base flow is estimated to have originated after 1995 (residence time less than 11 years). These findings have important implications on the length of time required before water-quality improvements in Broad Brook can be observed following implementation of BMPs.

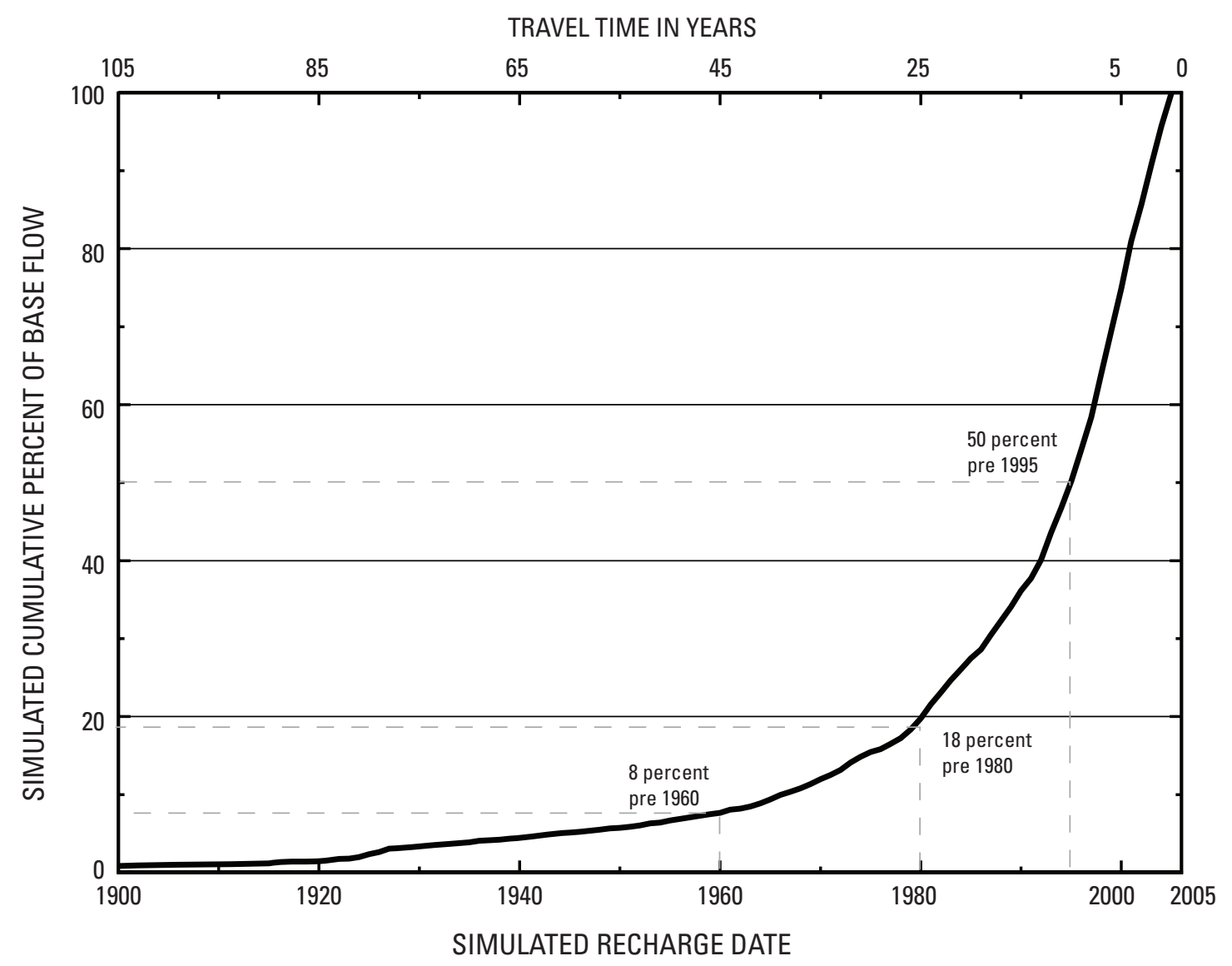

Figure 17. Simulated cumulative curve of percent of ground-water discharge in year 2006 from Broad Brook Basin by simulated year/age of recharge. 


\section{Scenarios of Future Nitrate Nitrogen Loads from Ground-Water Discharge}

Data from the MODFLOW/MODPATH simulations were used to simulate future base-flow loads of nitrate nitrogen. The calculations used information from the model simulations on (1) the recharge rate to each cell in the model from MODFLOW simulations and (2) the ground-water travel time from each model cell at the water table to discharge to a surface-water body. Additional information used included (3) the dominant land-use category of each model cell in 2002 based on the University of Connecticut land-use and land-cover data set (Civco and Hurd 2003), and (4) the estimated average concentrations of nitrate at the water table for each of the land-use/land-cover categories listed in table 4.

Simulations of future nitrate loads from ground-water discharge were based on the following assumptions:

1. Future conditions of recharge resemble the long-term average conditions simulated in this study.

2. Nitrogen load to Broad Brook from ground-water discharge is currently at a steady state. This assumption is based on the "time" variable in the load estimation from "ESTIMATOR" which was not statistically significant, indicating no trend in nitrate nitrogen load with time.

3. Current load of nitrate to the water table (based on landuse/land-cover for 2002) is not substantially different from the input associated with the water that is discharging to Broad Brook. This water is of mixed age as shown in figure 17.

4. For most simulations, an average concentration of nitrate was used to correspond to each land-use/land-cover category. In reality, there are likely areas that are higher or lower in concentration depending upon the intensity of the land use and the agricultural crops.

5. Denitrification generally is not occurring in ground water, as determined at most of the selected ground-water sampling sites in this study. The concentrations of nitrate used in this analysis may include the effects of nitrogen loss/denitrification in the unsaturated zone or the groundwater/surface-water interface and reductions that occur on an annual basis from instream biological processes.

6. BMPs were assumed to begin immediately over all areas in a targeted land use. In reality, BMPs, if implemented, are likely to be phased in over time. The existing storage of nitrogen in the soil will take some time to deplete, and changes to the concentrations of nitrate reaching the water table are likely to be gradual.

Potential BMPs that might be applied to agricultural areas include implementing nutrient-management plans. These plans could minimize the amount of available nutrients for loss to the water table by reducing nitrogen applications to an amount equal to the crop requirements, based on soil testing for nutrients. Residential BMPs include reducing fertilizer application based on soil test recommendations. Other residential and agri- cultural BMPs might include restoring vegetation to areas that currently receive fertilizer applications, and enhancing stream and wetland buffer areas. Monitoring the timing of fertilizer and manure applications may be helpful in reducing the load to the water table. Most ground-water recharge occurs during the nongrowing season, and nutrients applied to these areas during this time period may be more likely to reach the water table.

The scenarios tested involved reducing concentrations of nitrate nitrogen in recharging ground water at the water table beneath urban (developed and turf and grass categories in table 4) and agricultural (other grasses and agriculture category in table 4) land areas, applying the reduced nitrate concentrations in the discharge at time periods equal to or greater than the simulated travel time of ground water, and plotting the simulated load of nitrate in the discharge at specified times in the future. The purpose of the simulations is to provide some understanding of the time required for water-quality improvements to be observed in Broad Brook. Scenario 1 assumes that concentrations of nitrate nitrogen in recharging ground water at the water table beneath urban and agricultural land can be reduced to concentrations similar to those currently observed in shallow ground water beneath forested land (0.14 mg/L, table 4) (Grady, 1994; Grady and Mullaney, 1998). This scenario shows a 50percent reduction in the base-flow load of nitrogen in just over 10 years and a 70-percent reduction in 20 years (fig. 18, table 5).

Scenario 2 assumes that concentrations of nitrate nitrogen in recharging ground water at the water table can be reduced to achieve the USEPA Ecoregion XIV recommended nutrient-criteria value for streams of $0.7 \mathrm{mg} / \mathrm{L}$ (U.S. Environmental Protection Agency, 2000). Nitrate nitrogen concentrations were reduced to $0.7 \mathrm{mg} / \mathrm{L}$ at the water table beneath urban and agricultural land. This scenario shows a 50-percent reduction in the base-flow load of nitrate after 14 years and a 75-percent reduction in 30 years (fig. 18, table 5).

Scenario 3 assumes that concentrations of nitrate in recharging ground water at the water table under urban and agricultural land will be reduced by 50 percent. This scenario shows about a 25-percent reduction in the base-flow load of nitrate in about 10 years and a 45-percent reduction in 40 years (fig. 18, table 5).

Scenario 4 assumes that concentrations of nitrate nitrogen in recharging ground water at the water table under lands that were urban and agricultural in 2002 will be reduced by 10 percent. Under this scenario, a 7.2-percent reduction in base-flow load of nitrate could be expected in 20 years (fig. 18, table 5). This reduction is consistent with the Long Island Sound nitrogen TMDL calculation, which mandates a 10-percent decrease in loads of nonpoint nitrogen from urban and agricultural land by 2015 (New York Dept. of Environmental Conservation/Connecticut Dept. of Environmental Protection, 2000). If this scenario were to be applied in 2006, a reduction of 2.6 to 5 percent could by expected by 2015 .

Scenario 5 assumes concentrations of nitrate to the water table from lands that were urban and agricultural in 2002 are reduced by 5 percent. Under this scenario, a 3.6-percent reduction in base-flow load of nitrate could occur in 20 years (fig. 18, table 5). 


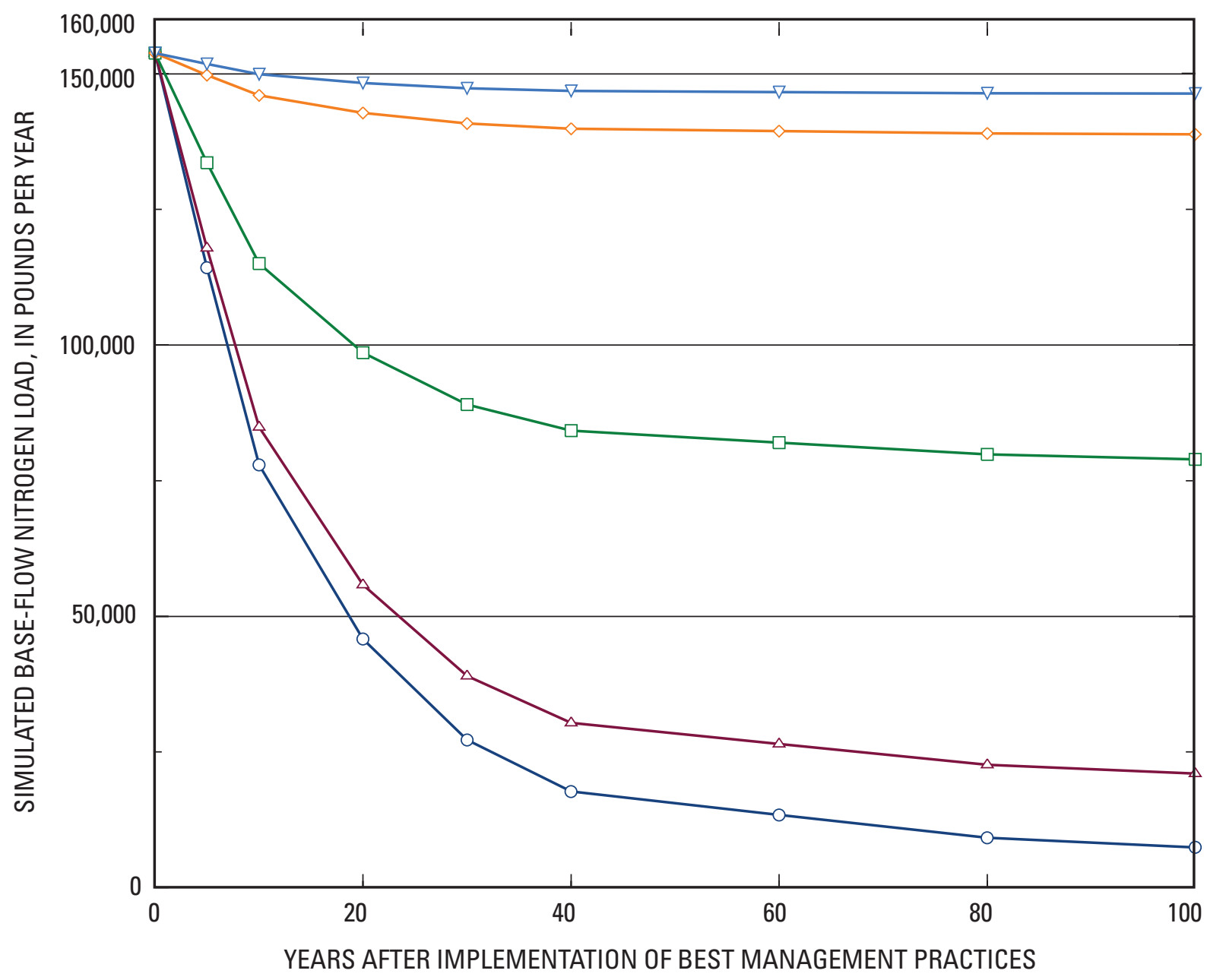

Nitrate nitrogen concentrations in recharging ground water beneath urban and agricultural areas reduced:

Scenario

$1 \quad$ - To concentrations from forested land (0.14 milligrams per liter (mg/L))

$2 \longrightarrow$ To U.S. Environmental Protection Agency Ecoregion XIV recommended nutrient criteria $(0.71 \mathrm{mg} / \mathrm{L})$

$3 \longrightarrow \square-B y 50$ percent

$4 \longrightarrow$ By 10 percent

$5 \longrightarrow$ By 5 percent

Figure 18. Simulated future base-flow load of nitrate nitrogen from Broad Brook Basin, north-central Connecticut, under five scenarios for reductions in concentration of nitrate in recharging ground water. 
Table 5. Simulated future base-flow load of nitrate nitrogen from Broad Brook Basin, north-central Connecticut, under five scenarios for reductions in concentration of nitrate in recharging ground water.

[Loads are in pounds]

\begin{tabular}{ccccccccccc}
\hline \multirow{2}{*}{$\begin{array}{c}\text { Time in } \\
\text { years }\end{array}$} & \multicolumn{2}{c}{ Scenario 1 } & \multicolumn{2}{c}{ Scenario 2 } & \multicolumn{2}{c}{ Scenario 3 } & \multicolumn{2}{c}{ Scenario 4 } & \multicolumn{2}{c}{ Scenario 5 } \\
\cline { 2 - 11 } & Load & $\begin{array}{c}\text { Percent } \\
\text { reduction }\end{array}$ & Load & $\begin{array}{c}\text { Percent } \\
\text { reduction }\end{array}$ & Load & $\begin{array}{c}\text { Percent } \\
\text { reduction }\end{array}$ & Load & $\begin{array}{c}\text { Percent } \\
\text { reduction }\end{array}$ & Load & $\begin{array}{c}\text { Percent } \\
\text { reduction }\end{array}$ \\
\hline 0 & 153,800 & 0.0 & 153,800 & 0.0 & 153,800 & 0.0 & 153,800 & 0.0 & 153,800 & 0.0 \\
5 & 114,300 & 25.7 & 117,900 & 23.4 & 133,600 & 13.1 & 149,800 & 2.6 & 151,800 & 1.3 \\
10 & 77,930 & 49.3 & 84,870 & 44.8 & 115,000 & 25.2 & 146,100 & 5.0 & 149,900 & 2.5 \\
20 & 45,820 & 70.2 & 55,820 & 63.7 & 98,580 & 35.9 & 142,800 & 7.2 & 148,300 & 3.6 \\
30 & 27,210 & 82.3 & 39,000 & 74.6 & 89,050 & 42.1 & 140,900 & 8.4 & 147,300 & 4.2 \\
40 & 17,720 & 88.5 & 30,360 & 80.3 & 84,200 & 45.3 & 139,900 & 9.1 & 146,900 & 4.5 \\
60 & 13,410 & 91.3 & 26,500 & 82.8 & 81,990 & 46.7 & 139,500 & 9.3 & 146,600 & 4.7 \\
80 & 9,186 & 94.0 & 22,630 & 85.3 & 79,830 & 48.1 & 139,000 & 9.6 & 146,400 & 4.8 \\
100 & 7,404 & 95.2 & 21,000 & 86.3 & 78,930 & 48.7 & 138,800 & 9.8 & 146,300 & 4.9 \\
\hline
\end{tabular}

\section{Summary and Conclusions}

A study of the loads of nitrogen and phosphorus in Broad Brook Basin was conducted by the U.S. Geological Survey, in cooperation with the Connecticut Department of Environmental Protection, during 2002-2005. Broad Brook Basin is a 15.8square mile basin in north-central Connecticut that is underlain by glacial stratified deposits, glacial till, and arkosic and crystalline bedrock. Land use is dominated by agricultural and forested land. Although ground-water discharge dominates the annual discharge of water in basins with extensive glacial stratified deposits, the role of ground-water discharge often is not considered in the implementation of Best Management Practices (BMPs) to reduce nitrogen load. Analysis of the stream base-flow record at Broad Brook from 1993-2004 indicated that $18.6 \mathrm{in}$. (82 percent) of the average annual runoff of $22.7 \mathrm{in}$. was during base flow, and that ground-water discharge is the largest component of streamflow. The investigation focused on determining the load of nitrate nitrogen to Broad Brook from ground-water discharge, and estimating the time required for improvements in ground-water quality to be evident in streamwater quality.

Ground-water samples from wells in Broad Brook Basin contained elevated concentrations of nitrite plus nitrate nitrogen as high as 9.7 milligrams per liter $(\mathrm{mg} / \mathrm{L})$, which is about 69 times larger than concentrations estimated for undeveloped forested areas in Connecticut. Dissolved gas measurements indicated that denitrification was limited to two samples with an excess 2 to $3 \mathrm{mg} / \mathrm{L}$ of nitrogen gas, and low nitrogen and dis- solved oxygen. The majority of samples contained concentrations of nitrite plus nitrate and dissolved oxygen greater than 2 $\mathrm{mg} / \mathrm{L}$. Concentrations of dissolved phosphorus were low except for two samples with concentrations of about $0.1 \mathrm{mg} / \mathrm{L}$.

The apparent age of ground-water samples was determined using tritium $\left({ }^{3} \mathrm{H}\right)$, tritium/helium-3 $\left({ }^{3} \mathrm{H} /{ }^{3} \mathrm{He}\right)$, and sulfur hexafluoride $\left(\mathrm{SF}_{6}\right)$ methods, and ranged from 2.4 to greater than 50 years. Two samples contained ${ }^{3} \mathrm{H}$ concentrations that indicate they were recharged before the peak of atmospheric nuclear testing in the mid-1960's. Ages determined from $\mathrm{SF}_{6}$ samples generally were younger than those determined using ${ }^{3} \mathrm{H} /{ }^{3} \mathrm{He}$, indicating the possibility of mixing of younger and older waters or a natural source of $\mathrm{SF}_{6}$ from geologic materials.

Loads of nitrogen and phosphorus from Broad Brook Basin from 1993-2004 were estimated using a multiple linearregression model. Loads of total nitrogen from the basin ranged from 117,000 to 270,000 pounds per year (lb/yr), and the yield was about 10 times larger than the yield in forested basins in Connecticut. About 80 percent of the load of total nitrogen was nitrate nitrogen, and the remainder was total ammonia plus organic nitrogen and nitrite. Concentrations of nitrogen exceeded U.S. Environmental Protection Agency (USEPA) Ecoregion XIV nitrogen criteria in all samples collected. The base-flow load of nitrate for water years 1993-2004 was estimated to be about 71 percent of the average load of total nitrogen from the basin, or 88,700 to 190,000 pounds (lb), indicating that ground-water discharge is the major source of nitrogen to Broad Brook. Loads of nitrate nitrogen delivered to streams from ground water may be larger than estimates determined 
from analysis of base-flow nitrate nitrogen concentrations and flows because of instream losses.

Annual loads of total phosphorus ranged from 2,330 to 14,400 lb. Dissolved phosphorus was about 71 percent of the annual load. Phosphorus yields were about five times larger than the yield in forested basins in Connecticut, and most samples exceeded the USEPA Ecoregion XIV phosphorus criteria of $0.031 \mathrm{mg} / \mathrm{L}$. The base-flow load of dissolved phosphorus was about 40 percent of the annual load of dissolved phosphorus, indicating that the majority of phosphorus was delivered to Broad Brook during storm events. Phosphorus in base flow likely includes phosphorus from ground-water discharge, as well as phosphorus released from storage in impoundment or streambed sediments.

Nutrient samples were collected and streamflow measurements were made in subbasins of Broad Brook Basin during a low-flow condition during September 2002. The low-flow synoptic sampling indicated that much of the nitrogen load originated from two subbasins, and that there was some attenuation of nitrogen loads near the basin outlet at Broad Brook Millpond. Analysis of the phosphorus data indicates release of phosphorus from impoundment sediments in two subbasins.

A finite-difference ground-water-flow model (MODFLOW) was used in conjunction with a particle-tracking (MODPATH) program to simulate the ground-water-flow system and flow paths in Broad Brook Basin. The ground-water model was calibrated with measurements of head, with streamflow collected during average base-flow conditions during October 2003, and with water levels from well-completion reports in bedrock wells in upland areas. Results of groundwater-age determinations were used to calibrate the MODPATH particle-tracking simulation by adjusting aquifer porosity to obtain the best match. The simulated discharge from the ground-water-flow model to streams contained water that was a mixture of different ground-water ages. The simulation indicated that 50 percent of the ground-water discharge to streams in Broad Brook Basin was recharged since 1995 and the other 50 percent was recharged before 1995 , including about 8 percent that was recharged before 1960 .

Future loads of nitrate nitrogen from ground water to Broad Brook following the implementation of BMPs were simulated by reducing the concentration of nitrate nitrogen at the water table. The calculations included simulated recharge rates to each cell in the model, along with nitrate nitrogen concentrations estimated for the dominant land use and the ground-water travel time (until discharge to a surface-water body) associated with each cell.

Scenarios were developed to reduce concentrations of nitrate nitrogen in recharging ground water beneath urban and agricultural lands: (1) to typical values from forested areas in Connecticut, (2) to concentrations established by the USEPA Ecoregion XIV nutrient criteria, (3) a 50-percent reduction in concentrations beneath urban and agricultural areas, (4) a 10percent reduction in concentrations beneath urban and agricultural areas, and (5) a 5-percent reduction in concentrations beneath urban and agricultural areas. Assuming an instanta- neous reduction in nitrate concentrations at the water table, a 25 -percent reduction in base-flow load of nitrate nitrogen could be achieved in just over 5 years under scenarios 1 and 2; the same reduction would take about 10 years under scenario 3 . A 9-percent reduction would take place in 40 years under scenario 4. A 50-percent reduction in the base-flow nitrate nitrogen load could be achieved in little more than 10 years under scenario 1 and in about 15 years under scenario 2. A 50-percent reduction would not be achieved in 100 years under scenario 3, but would reach about 45 percent in 40 years.

The simulations described above also could be used to predict the maximum base-flow load of nitrate nitrogen that could be achieved in the shortest amount of time. The simulations suggest that in this basin, and in other similar basins in Connecticut underlain by extensive glacial stratified deposits, the time lag can be substantial to see the effects of land use on the quality of water discharged to streams from ground water. This finding may be important in the expectations for water-quality improvements from land-use changes or BMPs. The findings also have significance with regard to BMPs that enhance infiltration of stormwater, but may contribute to a longer-term problem of nitrate discharge to streams. Further analysis of groundwater travel times from upland areas would be useful to enhance the understanding of the ground-water discharge time lag in Connecticut.

\section{References}

Bohlke, J.K., 2006, TRACERMODEL1, Excel workbook for calculation and presentation of environmental tracer data for simple groundwater mixtures, in IAEA Guidebook on the Use of Chlorofluorocarbons in Hydrology: Vienna, International Atomic Energy Agency, p. 239-243.

Busenberg, E., and Plummer, L.N., 2000, Dating young groundwater with sulfur hexafluoride-Natural and anthropogenic sources of sulfur hexafluoride: Water Resources Research, v. 36, p. 3011-3303.

Cervione, M.A., Jr., Weiss, L.A., Bohr, J.R., and Bingham, J.W., 1989, Water resources data, Connecticut, water year 1987: U.S. Geological Survey Water-Data Report CT-87-1, $295 \mathrm{p}$.

Civco, D.L., Arnold, C.L., and Hurd, J.D., 1998, Land use and land cover mapping for the Connecticut and New York portions of the Long Island Sound Watershed: Office of Long Island Sound Programs, Connecticut Department of Environmental Protection, Research Project CWF 330-R Technical Completion Report, unpaginated.

Clausen, J.C., Guillard, K., Sigmund, C.M., and Martin Dors, K., 2000, Water quality changes from riparian buffer restoration in Connecticut: Journal of Environmental Quality, v. 29, p. 1751-1761. 
Clausen, J.C., Guillard, K., Martin, K., Saldi, K., Sigmund, C., and Wayland, K., 1998, Final report-Riparian zone restoration to treat nonpoint pollutants: Storrs, Connecticut, University of Connecticut Department of Natural Resources Management and Engineering, variously paginated.

Cohn, T.A., 1988, Adjusted maximum likelihood estimation of the moments of lognormal populations from Type 1 censored samples: U.S. Geological Survey Open-File Report 88-350, $34 \mathrm{p}$.

Cohn, T.A., Caulder, D.L., Gilroy, E.J., Zynjuk, L.D., and Summers, R.M., 1992a, The validity of a simple statistical model for estimating fluvial constituent loads-An empirical study involving nutrient loads entering Chesapeake Bay: Water Resources Research, v. 28, no. 9, p. 2353-2363.

Cohn, T.A., DeLong, L.L., Gilroy, E.J., Hirsch, R.M., and Wells, D.K., 1989, Estimating constituent loads: Water Resources Research, v. 25, no. 5, p. 937-942.

Cohn, T.A., Gilroy, E.J., and Baier, W.G., 1992b, Estimating fluvial transport of trace constituents using a regression model with data subject to censoring: Proceedings of the Joint Statistical Meeting, Boston, August 9-13, 1992, p. 142152.

Colton, R.B., 1965, Geologic map of the Broad Brook quadrangle, Hartford and Tolland Counties, Connecticut: U.S. Geological Survey Geologic Quadrangle Map GQ-434, scale $1: 24,000$.

Colton, R.B., 1972, Surficial geologic map of the Ellington quadrangle, Hartford and Tolland Counties, Connecticut: U.S. Geological Survey Geologic Quadrangle Map GQ-965, scale 1:24,000.

Connecticut Department of Environmental Protection, 2004, 2004 list of Connecticut waterbodies not meeting water quality standards: Hartford, Connecticut, Department of Environmental Protection, 82 p., (accessed on January 23, 2006, on the World Wide Web at http://dep.state.ct.us/wtr/wq/2004_303d_final.pdf).

Frink, C.R., 1969, Water pollution potential estimated from farm nutrient budgets: Agronomy Journal, v. 61, p. 550-553.

Gilroy, E.J., Hirsch, R.M., and Cohn, T.A., 1990, Mean square error of regression-based constituent transport estimates: Water Resources Research, v. 26, no. 9, p. 2069-2077.

Grady, S.J., 1994, Effects of land use on quality of water in stratified-drift aquifers in Connecticut, Chapter B, Analysis of nonpoint-source ground-water contamination in relation to land use: U.S. Geological Survey Water-Supply Paper 2381, $56 \mathrm{p}$.

Grady, S.J., and Mullaney, J.R., 1998, Natural and human factors affecting shallow water quality in surficial aquifers in the Connecticut, Housatonic, and Thames River Basins: U.S. Geological Survey Water-Resources Investigations Report 98-4042, $81 \mathrm{p}$.

Harbaugh, A.W., Banta, E.R., Hill, M.C., and McDonald, M.G., 2000, MODFLOW-2000, The U.S. Geological Survey modular ground-water model-User guide to modularization concepts and the ground-water flow process: U.S. Geological Survey Open-File Report 00-92, 121 p.
Harman, J., Robertson, W.D., Cherry, J.A., and Zanini, L., 1996, Impacts on a sand aquifer from an old septic system-Nitrate and phosphate: Ground Water, v. 34, no. 6, p. 1105-1114.

Lindsey, B.D., Phillips, S. W., Donnelly, C.A., Speiran, G.K., Plummer, L.N., Bohlke, J.K., Focazio, M.J., Burton, W.C., and Busenberg, E., 2003, Residence times and nitrate transport in ground water discharging to streams in the Chesapeake Bay watershed: U.S. Geological Survey WaterResources Investigations Report 03-4035, 201 p.

Mazzaferro, D.L., Handman, E.H., and Thomas, M.P., 1979, Water resources inventory of Connecticut, part 8, Quinnipiac River Basin: Connecticut Water Resources Bulletin 27, 88 p. Morrison, Jonathan, Provencher, P.L., Martin, J.W., and Norris, J.R., 2005, Water resources data, Connecticut, water year 2004: U.S. Geological Survey Water-Data Report CT-04-1, $380 \mathrm{p}$.

Mullaney, J.R., 1995, Hydrogeology and ground-water flow at the Muddy Brook riparian zone, north-central Connecticut: U.S. Geological Survey Water-Resources Investigations Report 94-4255, 31 p.

Mullaney, J.R., Schwarz, G.E., and Trench, E.C.T., 2002, Estimation of nitrogen yields and loads from basins draining to Long Island Sound, 1988-98: U.S. Geological Survey WaterResources Investigations Report 02-4044, 84 p.

Mullaney, J.R., and Zimmerman, M.J., 1997, Nitrogen and pesticide concentrations in an agricultural basin in north-central Connecticut: U.S. Geological Survey Water-Resources Investigations Report 97-4076, 13 p.

New York State Department of Environmental Conservation/Connecticut Department of Environmental Protection, 2000, A total maximum daily load analysis to achieve waterquality standards for dissolved oxygen in Long Island Sound: Albany, N.Y., and Hartford, Conn., 73 p.

Plummer, L.N., Michel, R.L., Thurman, E.M., and Glynn, P.D., 1993, Environmental tracers for age dating young ground water, in Alley, W.M., Regional ground-water quality: New York, Van Nostrand Rheinhold, p. 255-294.

Pollock, D.W., 1994, User's guide for MODPATH/MODPATH-PLOT, version 3-Particle tracking post-processing package for MODFLOW, the U.S. Geological Survey finitedifference ground-water flow model: U.S. Geological Survey Open-File Report 94-464, unpaginated.

Rodgers, John (compiler), 1985, Bedrock geological map of Connecticut: Connecticut Geological and Natural History Survey, Natural Resources Atlas Series Map, 2 sheets, scale 1:125,000.

Rutledge, A.T., 1998, Computer programs for describing the recession of ground-water discharge and for estimating mean ground-water recharge and discharge from streamflow records-Update: U.S. Geological Survey Water-Resources Investigations Report 98-4148, 43 p.

Santella, N., Ho, D.T., Schlosser, P., and Stute, M., 2003, Distribution of atmospheric $\mathrm{SF}_{6}$ near a large urban area as recorded in the vadose zone: Environmental Science and Technology, v. 37, no. 6, p. 1069-1074. 
Schlosser, P., Stute, M., Dorr, H., Sonntag, C., and Munich, K.O., 1988, Tritium/3He dating of shallow groundwater: Earth and Planetary Science Letters, v. 94, p. 245-256.

Solomon, D.K., and Sudicky, E.A., 1991, Tritium and helium 3 isotope ratios for direct estimation of spatial variations in groundwater recharge: Water Resources Research, v. 27, no. 9, p. 2309-2319.

Stone, J.R., Schafer, J.P., London, E.H., and Thompson, W.B., 1992, Surficial materials map of Connecticut: U.S. Geological Special Map, scale 1:125,000, 2 sheets.

Stone, J.R., Schafer, J.P., Haley London, E., DiGiacomoCohen, M.L., Lewis, R.S., and Thompson, W.B., 2005, Quaternary geology map of Connecticut and Long Island Sound basin: U.S. Geological Survey Scientific Investigations Map 2784, 71 p., 3 pl.

Thomas, M.P., 1966, Effect of glacial geology upon the time distribution of streamflow in eastern and southern Connecticut, in Geological Survey Research 1966: U.S. Geological Survey Professional Paper 550-B, p. B209- B212.

Trench, E.C.T., 2000, Nutrient sources and loads in the Connecticut, Housatonic, and Thames River Basins: U.S. Geological Survey Water-Resources Investigations Report 994236, 66 p.
University of Montana, Numerical Terradynamic Simulation Group, 2006, data retrieved from http://www.daymet.org.

U.S. Environmental Protection Agency, 2000, Ambient water quality criteria recommendations-Information supporting the development of State and Tribal nutrient criteria; rivers and streams in nutrient ecoregion XIV: Washington D.C., U.S. Environmental Protection Agency, Office of Water EPA 822-B00-022, 84 p.

U.S. Environmental Protection Agency, State of Connecticut, State of New York, Interstate Sanitation Commission, and National Oceanic and Atmospheric Administration, 1985, Long Island Sound estuarine study, water quality management strategy: $10 \mathrm{p}$.

Walter, D.A., Rea, B.A., Stollenwerk, K.G., and Savoie, J., 1996, Geochemical and hydrologic controls on phosphorus transport in a sewage-contaminated sand and gravel aquifer near Ashumet, Cape Cod, Massachusetts: U.S. Geological Survey Water-Supply Paper 2463, 89 p.

Wilde, F.D., and Radtke, D.B., eds., 1998, National field manual for the collection of water quality data-Field measurements: U.S. Geological Survey Techniques of WaterResources Investigations, book 9, variously paged. 


\section{Appendix 1. Development of Ground-Water- Flow Model for Broad Brook Basin}

\section{Description of Flow Model and Model Assumptions}

The MODFLOW ground-water-flow model for Broad Brook Basin uses a finite-difference grid with 55 rows and 100 columns. All cells in the model are 400 by 400 feet (ft) (fig. 11), and the model has four layers (fig. 1-2). The uppermost two layers represent the unconsolidated surficial deposits, or the top of the bedrock surface in areas where surficial materials are thin. The lowermost two layers simulate the bedrock aquifer to a minimum depth of $300 \mathrm{ft}$ and a maximum depth of $470 \mathrm{ft}$ (below land surface), depending upon the thickness of the surficial deposits. Layer 3 is $100 \mathrm{ft}$ thick, and layer 4 is $200 \mathrm{ft}$ thick. Model layers are assumed to be confined (fixed transmissivity), due to the numerical instability in the uppermost thin layers of the model, especially in the uplands.

The model is a steady-state simulation that was calibrated to measurements of ground-water levels and streamflow collected during a nearly average base-flow period in October 2003. The average base-flow period was identified using the output from the computer program PART, described previously. Additional calibration observations include water-level data from well-completion reports at 20 wells that were approximately located. These additional data were used to constrain the simulated water table in the upland areas at the eastern end of Broad Brook Basin.

Streamflow measurements used in the calibration were collected at the mouth of the basin at U.S. Geological Survey (USGS) station 01184490 on October 8, 2003. Streamflow measurements also were collected from 10 other sites for comparison of results with the simulation. The calibration for this model used a nonlinear regression technique to estimate parameters that minimize the sum of squared differences between observed and simulated heads and streamflows. The technique was developed by Cooley and Naff (1990) and included in the MODFLOW 2000 computer program by Hill and others (2000). Estimated parameters include hydraulic conductivity of bedrock units, glacial stratified deposits, and thick till, and the amount of recharge to glacial stratified deposits.

\section{Boundary Conditions}

The top of the model is a specified flow boundary, the value of which is equal to long-term recharge. The top of layer 1 is the water table. Initially, the top of the model was set to the land surface. After preliminary model runs, the simulated head in layer 1 was used as the top of layer 1 . This allowed for more accurate estimation of the hydraulic conductivity, which is affected by layer thickness when model layers are simulated as confined. Recharge rates used in this simulation are "effective recharge rates" and include the effects of ground-water evapo- transpiration. The edges of the model are simulated using a noflow boundary that corresponds to the Broad Brook Basin divide. It is possible that this boundary does not behave as a noflow boundary, because the drainage divide crosses an area of glacial stratified deposits in the downstream end of the valley, and it is therefore possible that some ground water may flow into or out of the basin by underflow. The bottom of the lower model boundary is simulated using a no-flow boundary that ranges from 300 to $470 \mathrm{ft}$ below land surface. The bottom of the model is in either arkosic or crystalline bedrock (fig. 1-2). The elevation of the bedrock surface was generally represented as the bottom of layer 2 in areas with thick till or glacial stratified deposits. The depth to bedrock was determined in these areas from geologic maps (Cushman and Colton, 1963; Colton, 1972; Ryder, 1972; Hyde and Colton, 1973; Handman and Ryder, 1974) and modified with depth information from well-completion reports.

\section{Ground-Water Recharge}

Recharge rates to glacial deposits were based on values developed from base-flow analysis of streams (Mazzaferro, 1979). This relation indicates that ground-water recharge to till is about 35 percent of the total runoff. In Broad Brook Basin, the annual mean runoff from 1993-2004 was 22.7 inches: therefore recharge to glacial till deposits is 35 percent of this value or about 7.9 inches per year (in/yr).

Ground-water recharge was estimated to be even lower in small parts of the basin with fine-grained deposits or swamp deposits overlying fine-grained materials. An evaluation of streamflow data collected during October 2003 indicates that, during base-flow conditions, subbasins containing these types of deposits had lower flows per square mile than basins without these deposits. A value of 4 in/yr was assigned to model cells containing these deposits.

Ground-water recharge to areas with coarse-grained glacial stratified deposits at the surface was estimated using optimal parameter estimates from MODFLOW. The simulation estimated a recharge rate of $24.6 \mathrm{in} / \mathrm{yr}$. This value is similar to recharge rates determined previously for ground-water-flow modeling studies in Connecticut (Starn and others 2000).

\section{Aquifer Properties}

Hydraulic conductivity of aquifer materials was assigned either on the basis of previous investigations or was estimated using MODFLOW. Hydraulic conductivities of glacial stratified deposits (with the exception of fine-grained materials), thick till, arkosic bedrock, and crystalline bedrock were estimated with the use of MODFLOW. Values of hydraulic conductivity were assigned using zone arrays in the MODFLOW simulation (table 1-1). The ratio of horizontal hydraulic conductivity to vertical hydraulic conductivity was assumed to be 1 . 


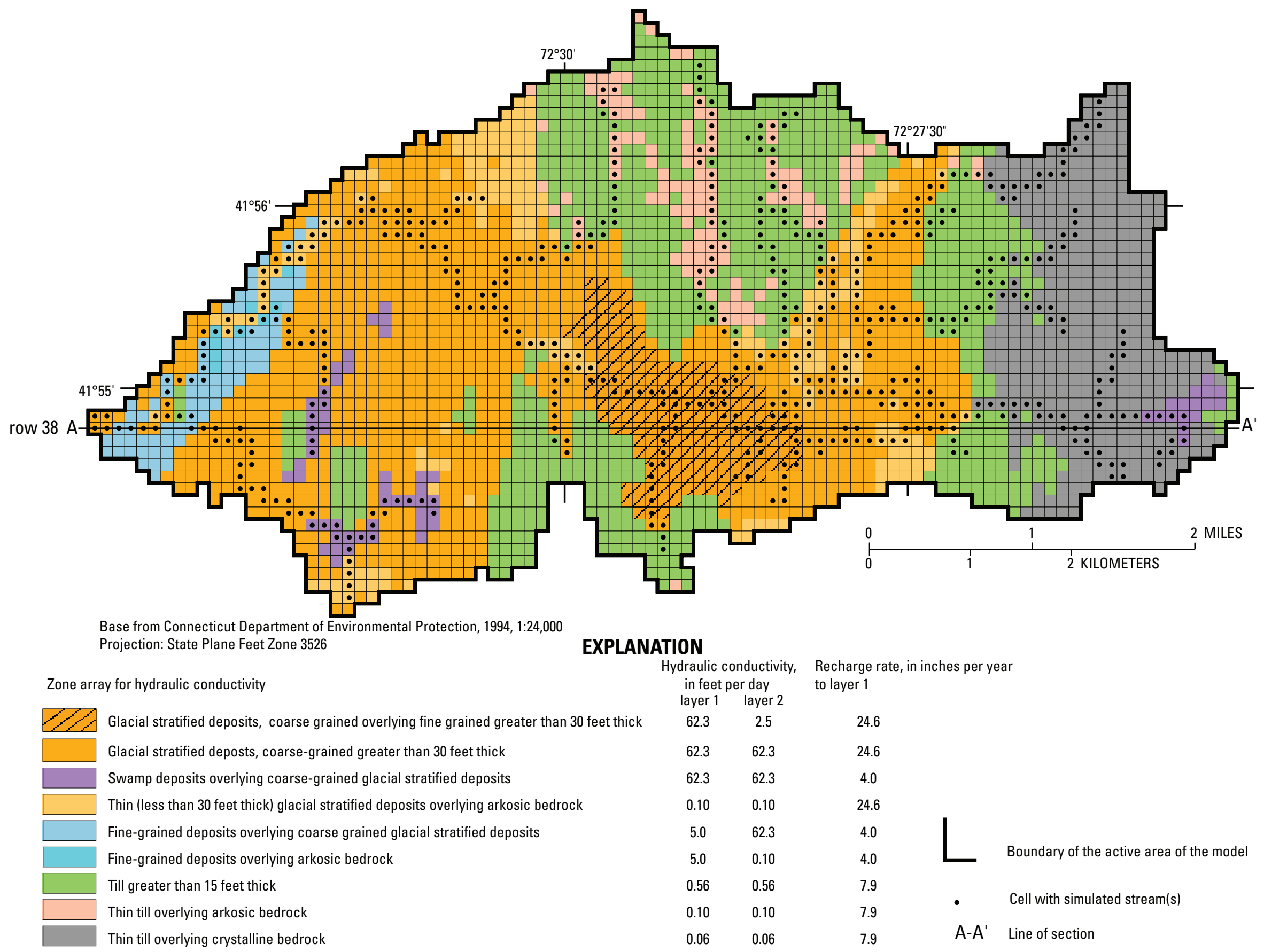

Figure 1-1. Extent of finite-difference ground-water-flow model grid, boundary conditions, and zone arrays for recharge and hydraulic conductivity, Broad Brook Basin, north-central Connecticut. 


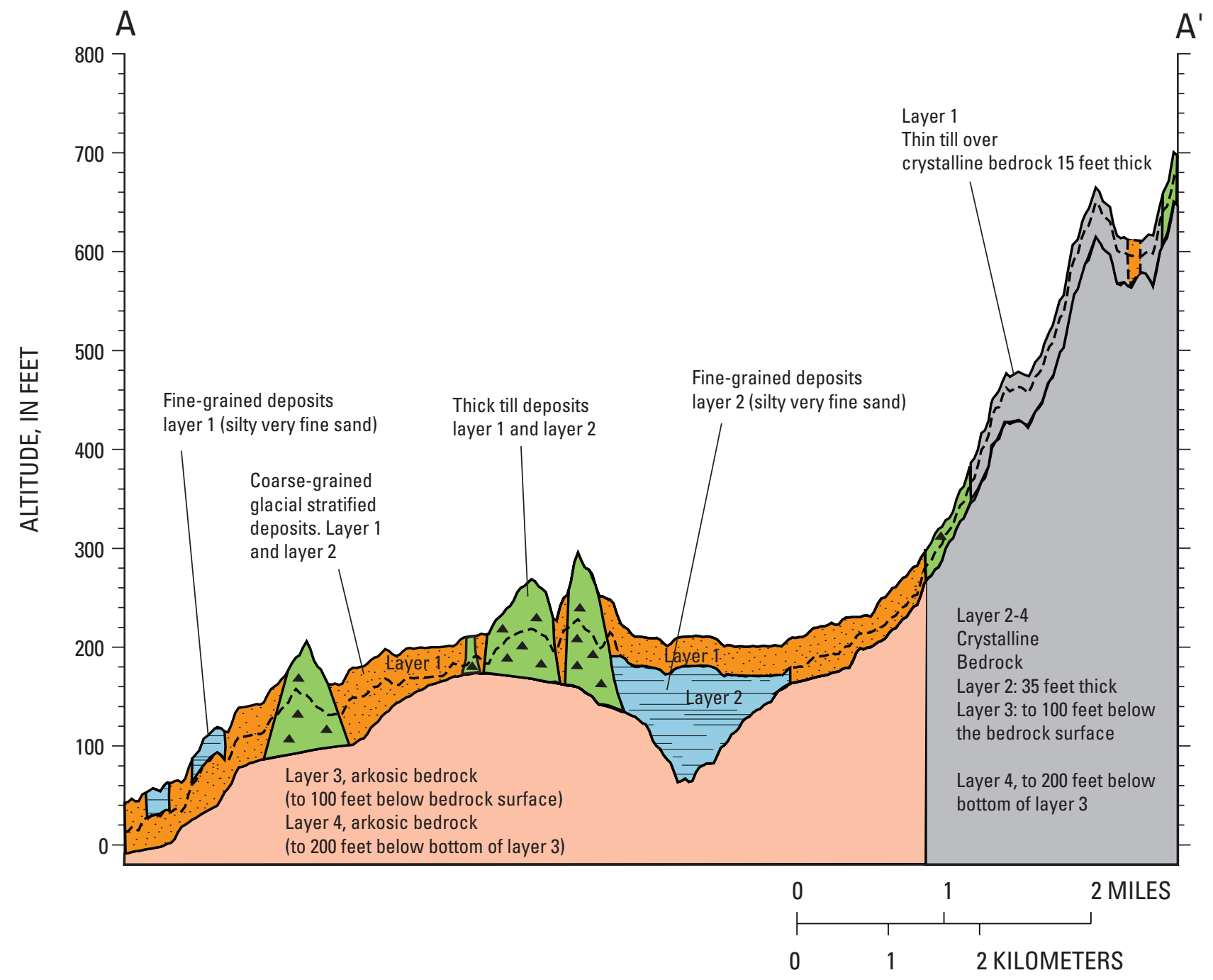

Figure 1-2. Generalized west-to east-cross section along row 38 in the finite-difference ground-water-flow model, showing model layers and hydraulic-conductivity zones, Broad Brook Basin, north-central Connecticut. 
Table 1-1. Values of hydraulic conductivity used in finite-difference ground-water-flow model, Broad Brook Basin, north-central Connecticut.

$[<$, value is less than value shown; >, value is greater than value show; *, value calculated using parameter estimation in MODFLOW and presented in this report in "Model Calibration and Hydrologic Budget"]

\begin{tabular}{|c|c|c|c|}
\hline Aquifer material & Method & $\begin{array}{l}\text { Hydraulic conductivity } \\
\text { used in model, } \\
\text { in feet per day }\end{array}$ & $\begin{array}{l}\text { Hydraulic conductivity } \\
\text { from previous studies, } \\
\text { in feet per day }\end{array}$ \\
\hline $\begin{array}{l}\text { Glacial stratified deposits (based on } \\
\text { median grain size of medium sand } \\
\text { or larger) }\end{array}$ & Nonlinear regression & $*$ & ${ }^{1}>20$ \\
\hline $\begin{array}{l}\text { Fine-grained glacial stratified } \\
\text { deposits (present near mouth of } \\
\text { Broad Brook Basin, and at depth, } \\
\text { fine to very fine sand and silt) }\end{array}$ & Historical values & 5.0 & ${ }^{1}<1.6-20$ \\
\hline Thick till & Historical values & $*$ & ${ }^{2} .02$ \\
\hline $\begin{array}{l}\text { Arkosic bedrock (potentially cov- } \\
\text { ered with till up to } 15 \text { feet thick) }\end{array}$ & Nonlinear regression & $*$ & ${ }^{2} .31-4.7$ \\
\hline $\begin{array}{l}\text { Crystalline bedrock (potentially } \\
\text { covered with till up to } 15 \text { feet thick) }\end{array}$ & Nonlinear regression & $*$ & ${ }^{2} .6$ \\
\hline
\end{tabular}

${ }^{1}$ Value from Mazzaferro and others (1979) fig. 35.

${ }^{2}$ Value from Melvin and others (1992).

A porosity of 0.30 was assigned to glacial stratified deposits. This value is within the range of reported porosities for sand and gravel (Freeze and Cherry, 1979). In areas of thick till (greater than $15 \mathrm{ft}$ ), a porosity of 0.25 was used. This value is consistent with values reported by Melvin (1992) for compact surface tills of the sedimentary rock provenance. The effective porosity (the total porosity minus the retention) of bedrock represents the porosity due to the density and aperture of bedrock fractures. The effective porosity of both the sedimentary (Portland Formation) and crystalline bedrock were assumed to be 0.005 ( 0.5 percent). This value is similar to values of total secondary porosity measured in sedimentary rocks in Durham, Connecticut, using square-array direct current resistivity of 1.1 to 2.7 percent (Melvin and others, 1995). Values reported in previous studies for secondary porosity of crystalline bedrock are limited. Hansen and Lane (1996) estimated the secondary porosity of crystalline bedrock in Millville and Uxbridge, Massachusetts, to be 0.004 .

\section{Internal Sources and Sinks of Water}

Ground water is removed from the modeled area primarily through stream discharge in this simulation, except for some limited domestic water use. Four active community supply wells withdraw an estimated 0.16 million gallons per day (Mgal/d). (J.J. Starn, U.S. Geological Survey, oral commun., 2005). In addition, there are some individual private wells in small areas of residential development that withdraw water from the bedrock aquifer. Based on data from the 1990 census, which included information on sources of potable water, an estimated 850 private supply wells in the study area withdraw water from the bedrock aquifer. This amounts to an estimated water use in 1990 of about $0.17 \mathrm{Mgal} / \mathrm{d}$, based on water use of 80 gallons per person per day (U.S. Geological Survey, 1995) and 2.5 people per household. Current water use likely is higher because of residential and commercial development since 1990. The majority of this water (estimated 85 percent) withdrawn by residential wells is returned through on-site septic systems.

Ground-water withdrawals were not included in this simulation because they represent only about 2 to 3 percent of the estimated annual recharge, if only withdrawals are considered, and about 0.4 percent if 85 percent is returned to the aquifer through septic systems. Therefore, for the purposes of this simulation, the ground-water withdrawals from public and private wells were considered to be negligible.

Streams were simulated using the stream package created for MODFLOW by Prudic (1989). The stream package uses a procedure that tracks the flow in streams that interact with ground water. This provides output for comparisons with streamflow measurements made for model calibration.

The active model area (fig. 1-1) contains 49 stream segments and 631 reaches. Segments are individual tributaries, or streams between tributaries; reaches are parts of stream segments crossing each model cell. Discharge between each stream reach and the adjacent aquifer is calculated, and streamflow is accumulated in a downstream direction. 
Streambed hydraulic conductivity was assumed to be 1 foot per day (ft/d), and streambed thickness was assumed to be $1 \mathrm{ft}$. The initial altitude of stream stage was determined using a digital elevation model. The values were then adjusted by visual comparison to USGS topographic maps with 10-ft contours. Stream altitude was assumed to be $2 \mathrm{ft}$ lower than stream stage. Stream width was assigned by stream order. Widths were estimated on the basis of measurements that were made during the low-flow water-quality sampling and streamflow measurements made in 2002 and 2003. First-order streams were assigned a width of $5 \mathrm{ft}$, second order streams were assigned a width of $10 \mathrm{ft}$, and third-order streams were assigned widths varying from $10 \mathrm{ft}$ in the upstream reaches to $36 \mathrm{ft}$ downstream, due to increases in the size of the drainage area.

\section{Model Calibration and Hydrologic Budget}

Five model parameters were estimated during calibration: (1) horizontal hydraulic conductivity of the glacial stratified deposits (with the exception of fine-grained materials near the mouth of the basin and with depth), (2) horizontal hydraulic conductivity of thick till, (3) horizontal hydraulic conductivity of arkosic bedrock with thin till, (4) horizontal hydraulic conductivity of crystalline bedrock with thin till, and (5) recharge to glacial stratified deposits (table 1-2.).
The ground-water-flow model was calibrated using waterlevel data collected on October 6-8, 2003 at 13 monitoring wells in Broad Brook Basin (fig. 1-3). This time period represented average ground-water levels (table 1-3) and average groundwater discharge conditions. Ground-water levels on October 68, 2003 were compared to the average water levels from four long-term observation wells in the basin (table 1-3). The comparison indicated that water levels in the basin were at nearly long-term average conditions. The determination of average discharge conditions was based on the base-flow analysis using PART. In addition to the wells that were measured, average ground-water levels from seven wells measured during previous studies were used in the calibration. Additional observations for upland areas in Broad Brook Basin (glacial till and bedrock uplands) were obtained from well-completion reports for 20 domestic wells completed in the bedrock aquifer. The wells were approximately located by street address. The purpose of these additional observations was to help constrain the water table in the model in upland areas where there was a lack of monitoring wells. Water levels from well-completion reports represent a wide range of water-level conditions; however, it is assumed that this range brackets long-term average conditions. Data from well-completion reports are subject to errors in location and altitude.

Table 1-2. Parameter estimates of hydraulic conductivity and recharge from nonlinear regression, finite-difference ground-water-flow model, Broad Brook Basin, north-central Connecticut.

\begin{tabular}{lccc} 
& \multicolumn{1}{c}{ Estimated parameter } & Value & Unit \\
\hline $\begin{array}{l}\text { Horizontal hydraulic conductivity of coarse-grained glacial } \\
\text { stratified deposits }\end{array}$ & 62.3 & Feet per day \\
$\begin{array}{l}\text { Horizontal hydraulic conductivity of thick till deposits } \\
\text { Horizontal hydraulic conductivity of crystalline bedrock } \\
\text { (including till covering up to 15 feet thick) }\end{array}$ & .56 & Feet per day \\
$\begin{array}{l}\text { Horizontal hydraulic conductivity of arkosic bedrock } \\
\text { (including till covering up to 15 feet thick) }\end{array}$ & .10 & Feet per day \\
\begin{tabular}{l} 
Recharge to coarse-grained glacial stratified deposits \\
\hline
\end{tabular} & 24.6 & Inches per year \\
\hline
\end{tabular}




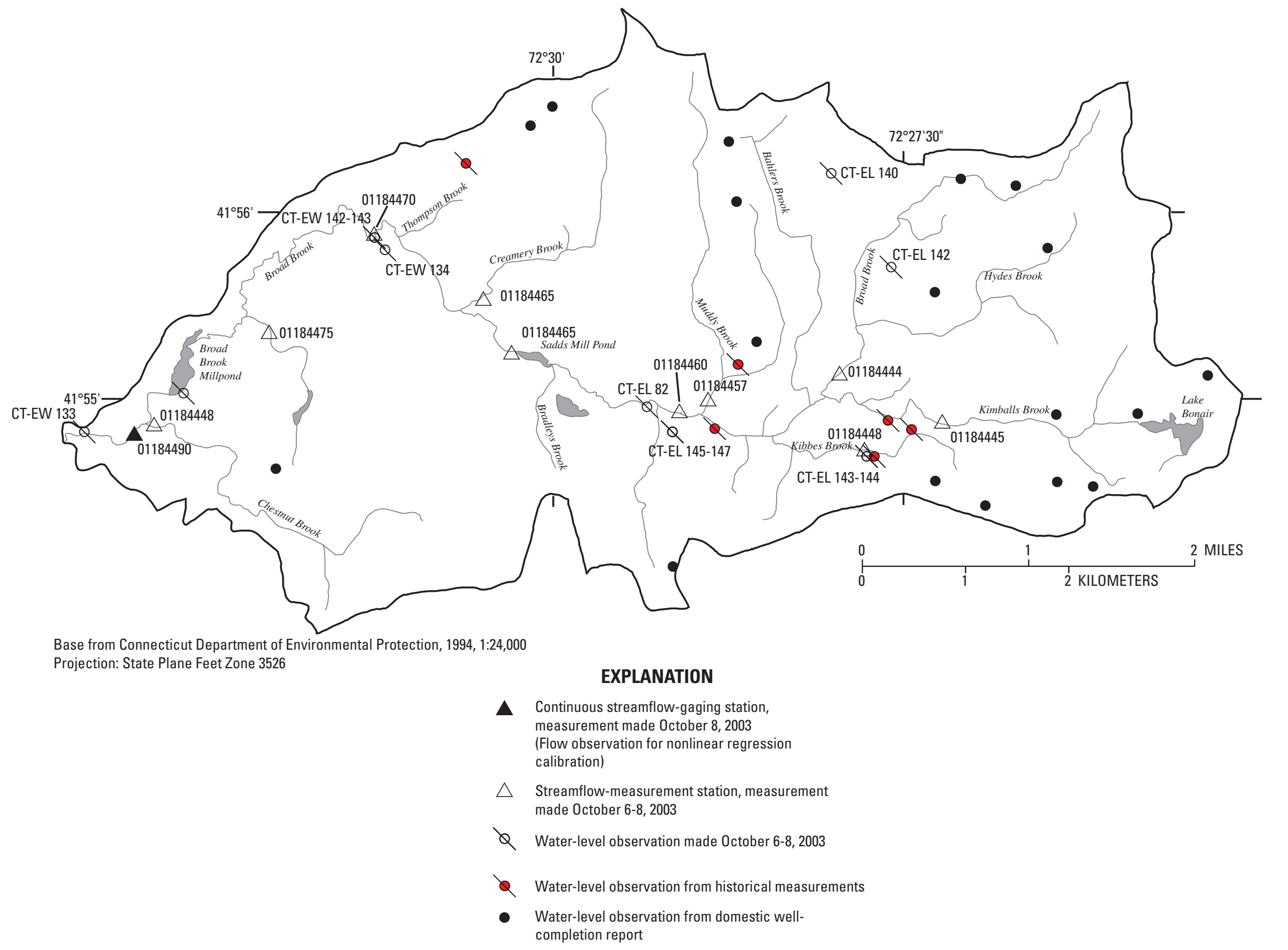

Figure 1-3. Location of measurements of ground-water levels and streamflow, Broad Brook Basin, north-central Connecticut. 
Table 1-3. Water levels in October 2003 and average water levels at selected U.S.Geological Survey network wells with long-term measurement records, Broad Brook Basin, north-central Connecticut.

[Water levels in feet below land surface; USGS, U.S. Geological Survey]

\begin{tabular}{llcccc}
\hline $\begin{array}{c}\text { USGS local well } \\
\text { identifier and } \\
\text { station number } \\
\text { (see fig. 6) }\end{array}$ & Town & $\begin{array}{c}\text { October 6-8, } \\
\text { 2003 } \\
\text { water level }\end{array}$ & $\begin{array}{c}\text { Average } \\
\text { water } \\
\text { level }\end{array}$ & $\begin{array}{c}\text { Period of } \\
\text { record used }\end{array}$ & Aquifer \\
\hline $\begin{array}{l}\text { CT-EW 133 } \\
\text { 415450072332201 }\end{array}$ & East Windsor & 5.06 & 5.03 & $1986-2004$ & Glacial stratified deposits \\
$\begin{array}{l}\text { CT-EW 134 } \\
\text { 415548072311301 }\end{array}$ & East Windsor & 50.55 & 50.64 & $1986-2004$ & Glacial stratified deposits \\
$\begin{array}{l}\text { CT-EL 82 } 82303801 \\
\text { 41561607230380 }\end{array}$ & Ellington & 5.86 & 5.92 & $1987-2004$ & Glacial stratified deposits \\
$\begin{array}{l}\text { CT-EL 140 } \\
\text { 415312072280201 }\end{array}$ & Ellington & 16.76 & 15.38 & $1993-2004$ & Till \\
\hline
\end{tabular}

The weighting process for water-level and streamflow measurements described by Hill (1998) was accomplished as follows. Data with a higher degree of accuracy were given a large weighting in the nonlinear regression calibration. The weights reflect possible measurement error in the data and are equal to the inverse of the variance of the measurement. The variance in the measurements for both streamflow and waterlevel measurements was determined subjectively, based on an assessment of, in the case of water-level measurements, the accuracy of the location and the land-surface altitude. The measurement error for monitoring wells was assumed to be half the contour interval ( $5 \mathrm{ft}$ ) of the USGS topographic map. This translates to a variance in water-level measurements for wells measured in October 2003 that was estimated to be 9.2 feet squared $\left(\mathrm{ft}^{2}\right)$ at the 90-percent confidence interval. This variance also was applied to the wells with average historical observations that were used in the calibration. Water levels from well-completion reports were assumed have an average error of $+/-20 \mathrm{ft}$. This translates to a variance of $147 \mathrm{ft}^{2}$ at the 90 -percent confidence interval. A comparison of the simulated heads against the measured heads generally indicates good agreement (fig. 1-4).

The unweighted errors (table 1-4) in the predictions of heads at observation points averaged $2.36 \mathrm{ft}$. The average errors were biased in a positive manner in upland areas ( $7.75 \mathrm{ft}$ ) and were biased in a negative manner in areas underlain by glacial stratified deposits $(-3.02 \mathrm{ft})$. Three upland areas in the model had simulated heads that were above land surface; these areas were generally the same areas as where layer 1 was assumed to contain bedrock covered by a thin veneer of glacial till. The reasons why simulated heads would be above land surface may be as follows: (1) the eastern boundary of the model is in an area of high relief, and some model cells contain as much as $90 \mathrm{ft}$ of relief within the cell. Simulated heads are assumed to be at the center of the cell, and therefore, the relation of the water table to land surface may be due to this coarse discretization of the model; (2) the stream drainage network as simulated may not allow for enough discharge of water to streams in these locations. This may be due to sub-first order streams that drain shallow water from thin glacial till deposits. These shallow processes are not simulated sufficiently due to the discretization and assumptions in this model; (3) recharge rates may be too large for these areas, or the recharge has more spatial variation in the upland areas of the basin.

Table 1-4. Summary of error statistics and comparison of observed and simulated ground-water levels, Broad Brook Basin, north-central, Connecticut, April 16-20, 2002.

Statistic Value

\begin{tabular}{lc}
\hline $\begin{array}{l}\text { Sum of squared weighted errors } \\
\begin{array}{l}\text { Average weighted error } \\
\text { (ground-water-level measurements) }\end{array}\end{array}$ & $-.18 \mathrm{feet}$ \\
$\begin{array}{l}\text { Average unweighted error } \\
\text { (ground-water-level measurements) }\end{array}$ & $2.36 \mathrm{feet}$ \\
\hline
\end{tabular}

Streamflow observations were made at 11 locations in Broad Brook Basin on October 6-8, 2003, during conditions of nearly average base flow. The average base flow during water years 1993-2004 was estimated to be 21 cubic feet per second $\left(\mathrm{ft}^{3} / \mathrm{s}\right)$. Streamflow was measured at $17 \mathrm{ft}^{3} / \mathrm{s}$ on October 8, 2003. Only one streamflow measurement from the most downstream 
station (01184490) was used in the parameter estimation (nonlinear regression) calibration. The nonlinear parameter estimation would not converge using all streamflow measurements. The additional streamflow observations that were not used in the parameter-estimation calibration were compared with the simulated streamflows in the MODFLOW as a means to assess model fit (fig. 1-5). There was generally good agreement between observed and simulated streamflows, especially in the mainstem of Broad Brook. Errors were largest among several of the smaller basins where streamflow was measured.

The hydrologic budget for Broad Brook Basin includes the simulated inputs and outputs from the ground-water system. In this steady-state simulation, inputs include recharge and leakage from streams; outputs include discharge to streams. The hydrologic budget for the basin simulation is in table 1-5.

Table 1-5. Model-calculated hydrologic budget for steady-state conditions.

\begin{tabular}{lcc}
\hline \multicolumn{1}{c}{ Budget item } & \multicolumn{2}{c}{ Volumetric rate } \\
\cline { 2 - 3 } & $\begin{array}{l}\text { Million } \\
\text { gallons } \\
\text { per day }\end{array}$ & $\begin{array}{c}\text { Cubic feet } \\
\text { per second }\end{array}$ \\
\hline Inflow & \\
\hline $\begin{array}{l}\text { Effective recharge from precipi- } \\
\text { tation }\end{array}$ & 11.9 & 18.4 \\
$\begin{array}{l}\text { Leakage from streams } \\
\text { Total inflow }\end{array}$ & 3.05 & 4.72 \\
\hline & 14.95 & 23.1 \\
\hline Discharge to rivers & Outflow & 23.1 \\
Total outflow & 14.95 & 23.1 \\
\hline
\end{tabular}

\section{Estimation of Ground-Water Travel Time}

The particle-tracking program MODPATH was used to simulate travel times from each model cell to the point of discharge in a stream or river. This was done to estimate the amount of time required for best-management practices (BMPs), which are targeted to improve concentrations of nitrate nitrogen at the water table, to have an effect on the nitrate load as measured at the basin outlet.

To constrain the travel times, arrays of particles were placed in the model at the locations of wells or well clusters. These particles were tracked in reverse to the recharge locations. The aquifer porosity was adjusted, within reasonable limits, to get the best match among the simulated travel times and those determined from ${ }^{3} \mathrm{H} /{ }^{3} \mathrm{He}$ and $\mathrm{SF}_{6}$ analyses (table 1-6). In the case of wells CT-EL 145 and CT-EL 146, the data from tritium analyses was determined to be more representative of the age of ground water than the $\mathrm{SF}_{6}$ values, due to a possible natural source of $\mathrm{SF}_{6}$ and very low concentrations of tritium.

Travel times simulated by the model are in the general range of those ages estimated from the use of tracers (table 1-6). Due to the proximity of several sampled wells to streams, and therefore the discharge area, it may be difficult to obtain an exact match to apparent ages determined with tracers. This is because of the convergence of flow towards areas of discharge, which is difficult to reproduce with relatively coarse model cells, both vertically and horizontally. There may be other reasons why apparent ages do not agree with simulated advective ages. For example, tracers can be affected by dispersion, diffusion into the bedrock matrix (Lindsey and Burton, 2003), and mixing of older and younger waters along the flow path.

The analysis of travel times has some limitations: (1) the lack of control and information on the ground-water travel times from the till and bedrock uplands. No samples of ground water from bedrock or till were collected and analyzed for tracers to determine apparent age. Currently, there are few published data on ages of ground water in till and bedrock in Connecticut; (2) the hydraulic conductivity of the stratified glacial aquifer is grouped into only two values-one value for coarsegrained deposits, and one value for fine-grained deposits. In reality, there is likely to be a wide range of values based on variations in grain size across the basin and with depth in the aquifer. Differences in these values may affect time of travel and local ground-water-flow directions. 


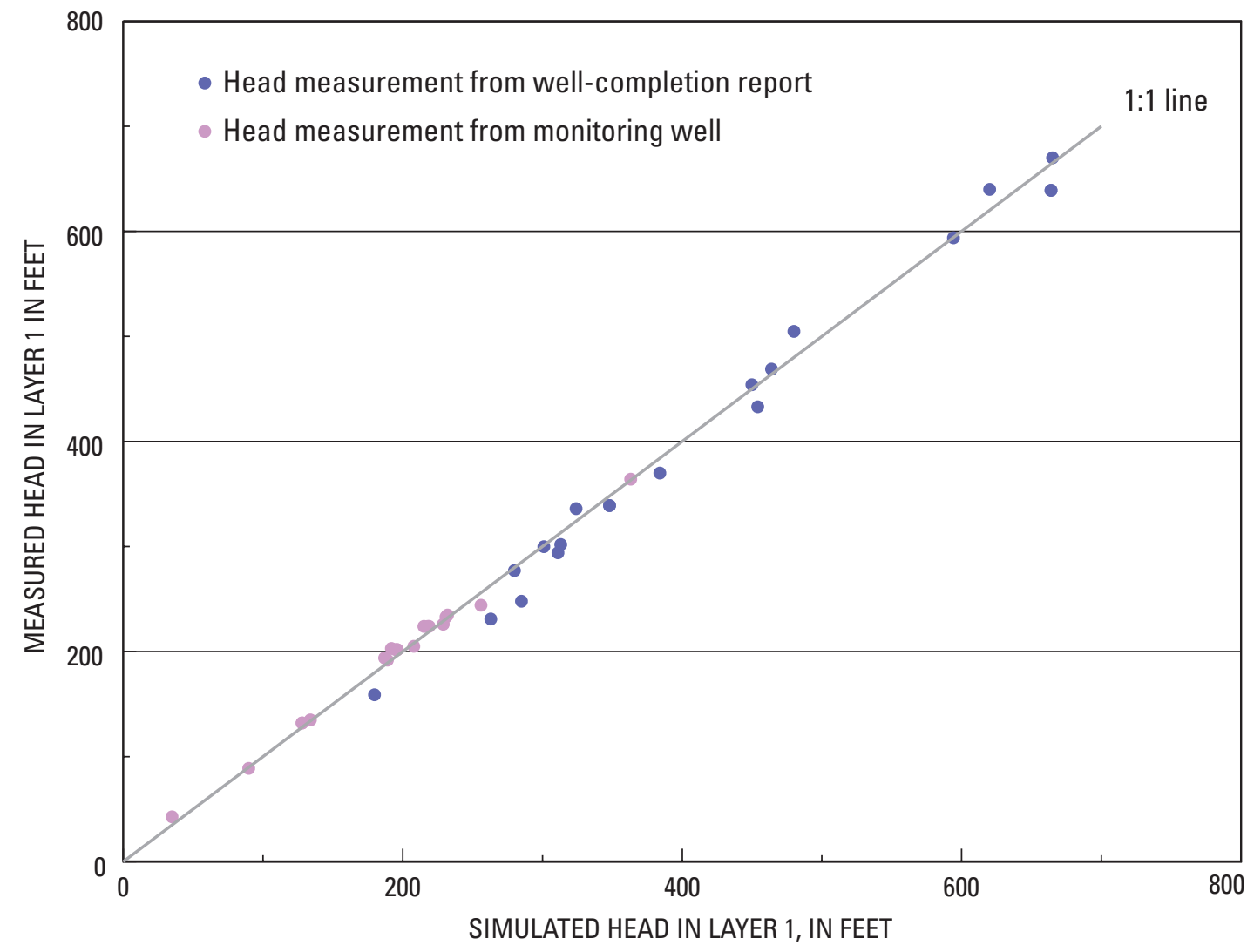

Figure 1-4. Simulated and measured hydraulic head, Broad Brook Basin, north-central Connecticut. 


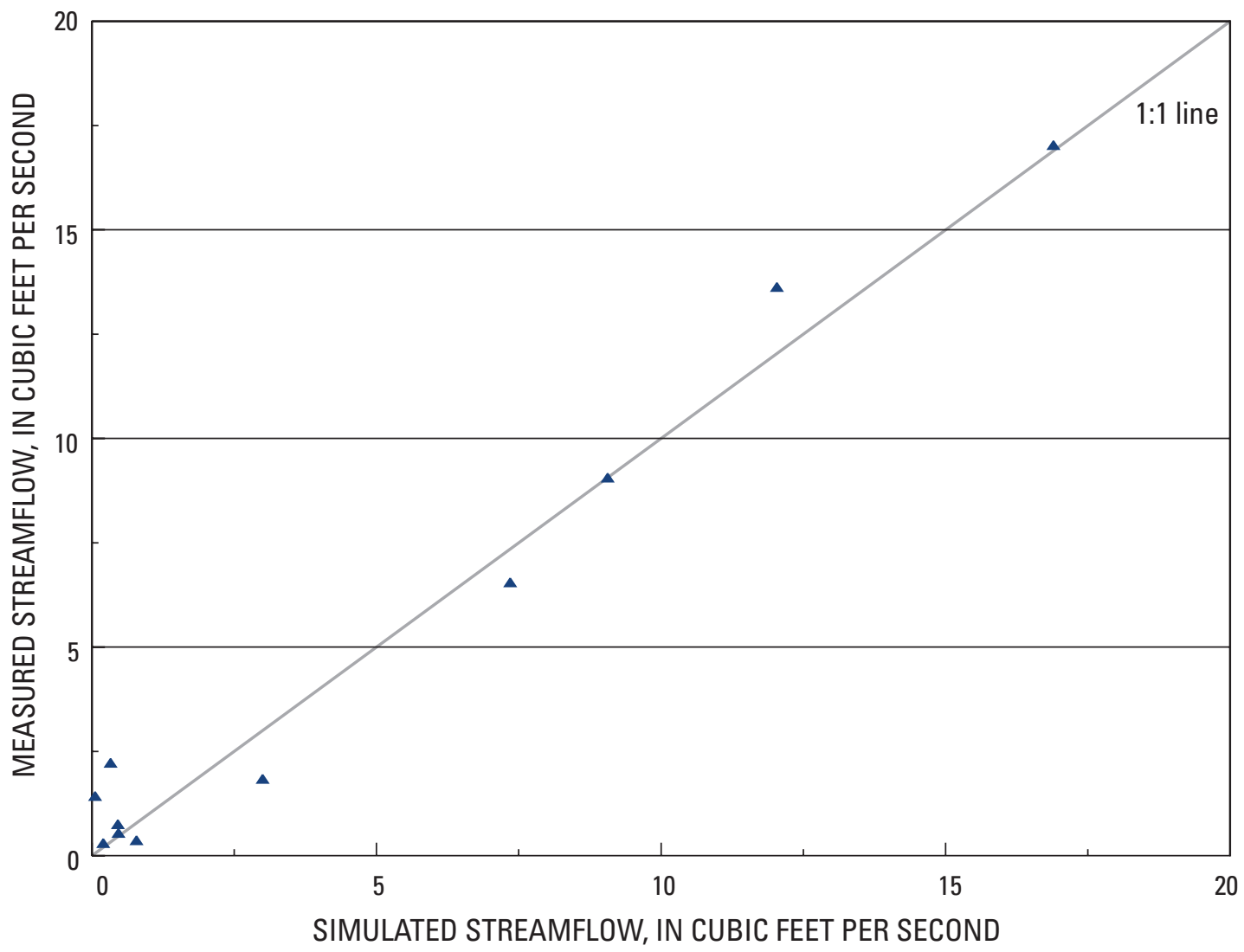

Figure 1-5. Simulated and measured streamflow, Broad Brook Basin, north-central Connecticut. 
Table 1-6. Simulated and apparent ages at selected monitoring wells, Broad Brook Basin, north-central Connecticut.

\begin{tabular}{cccc}
$\begin{array}{c}{\left[\mathrm{SF}_{6} \text {, sulfur hexafluoride; }{ }^{3} \mathrm{H} /{ }^{3} \mathrm{He} \text {, tritium/helium 3; }>\text {, greater than }\right]} \\
\begin{array}{c}\text { Local well } \\
\text { identifier } \\
\text { (fig. 1) }\end{array}\end{array}$ & $\begin{array}{c}\text { Simulated age from } \\
\text { MODPATH particle } \\
\text { tracking, in years }\end{array}$ & $\begin{array}{c}\text { Apparent age from } \\
\mathrm{SF}_{6} \text { analysis, } \\
\text { in years }\end{array}$ & $\begin{array}{c}\text { Apparent age from } \\
3^{3} /{ }^{3} \text { He analysis, } \\
\text { in years }\end{array}$ \\
\hline CT-EL 142 & 6.01 & 8.80 & 3.10 \\
CT-EL 143 & 30.65 & 10.80 & 23.40 \\
CT-EL 144 & 1.63 & 8.30 & -- \\
CT-EL 145 & 101.9 & 20.30 & $>50$ \\
CT-EL 146 & 26.61 & 17.80 & $>50$ \\
CT-EL 147 & 3.98 & 5.80 & 8.10 \\
CT-EW 133 & 22.95 & 18.30 & 14.00 \\
CT-EW 134 & 32.44 & 18.80 & 26.90 \\
CT-EW 142 & 14.02 & 9.80 & -- \\
CT-EW 143 & 10.08 & 11.30 & -- \\
\hline
\end{tabular}

\section{References}

Colton, R.B., 1972, Surficial geologic map of the Ellington quadrangle, Hartford and Tolland Counties, Connecticut: U.S. Geological Survey Geologic Quadrangle Map GQ-965, scale 1:24,000.

Cooley, R.L., and Naff, R.L., 1990, Regression modeling of ground-water flow: U.S. Geological Survey Techniques of Water Resources Investigations, book 3, chap. B4, 232 p.

Cushman, R.V., and Colton, R.B., 1963, Contour map of the bedrock surface of the Broad Brook quadrangle, Connecticut: U.S. Geological Survey Miscellaneous Investigations Series Map I-401, scale 1:24,000.

Freeze, R.A., and Cherry, J.A., 1979, Groundwater: Englewood Cliffs, New Jersey, Prentice-Hall Inc., 604 p.

Harbaugh, A.W., Banta, E.R., Hill, M.C., and McDonald, M.G., 2000, MODFLOW-2000, The U.S. Geological Survey modular ground-water model-User guide to modularization concepts and the ground-water flow process: U.S. Geological Survey Open-File Report 00-92, 121 p.

Handman, E.H., and Ryder, R.B., 1974, Contour map of the bedrock surface, Ellington quadrangle, Connecticut: U.S. Geological Survey Miscellaneous Field Study Map MF-604A, scale $1: 24,000$.

Hansen, B.P., and Lane, J.W., Jr., 1996, Orientation and characteristics of fractures in crystalline bedrock determined by surface and borehole geophysical surveys, Millville and Uxbridge, Massachusetts, in Bell, R.S., and Cramer, M.H., eds., Symposium on the Application of Geophysics to Engineering and Environmental Problems, Keystone, Colo., April 28-May 2, 1996, Proceedings: Wheat Ridge, Colorado, Environmental and Engineering Geophysical Society, p. 927-940.

Hill, M.C., 1998, Methods and guidelines for effective model calibration: U.S. Geological Survey Water-Resources Investigations Report 98-4005, 90 p.

Hill, M.C., Banta, E.R., Harbaugh, A.W., and Anderman, E.R., 2000, MODFLOW-2000, The U.S. Geological Survey modular ground-water model-User guide to the observation, sensitivity, and parameter-estimation processes and three post-processing programs: U.S. Geological Survey OpenFile Report 00-184, 209 p.

Hyde, R.C., and Colton, R.B., 1973, Depth to bedrock, Broad Brook quadrangle, Connecticut: U.S. Geological Survey Miscellaneous Field Study Map MF-451-G, scale 1:24,000.

Lindsey, B.D., and Burton, W.C., 2003, East Mahantango Creek watershed, in Lindsey, B.D., Phillips, S. W., Donnelly, C.A., Speiran, G.K., Plummer, L.N., Bohlke, J.K., Focazio, M.J., Burton, W.C., and Busenberg, E., 2003, Residence times and nitrate transport in ground water discharging to streams in the Chesapeake Bay watershed: U.S. Geological Survey Water-Resources Investigations Report 03-4035, $201 \mathrm{p}$.

Mazzaferro, D.L., Handman, E.H., and Thomas, M.P., 1979, Water resources inventory of Connecticut, part 8, Quinnipiac River Basin: Connecticut Water Resources Bulletin 27, 88 p. 
Melvin, R.L., Stone, J.R., Craft, P.A., Lane, J.W., Jr., and Davies, B.S., 1995, Geohydrology and water quality of the Durham Center area, Durham, Connecticut: U.S. Geological Survey Water-Resources Investigations Report 94-4237, 97 p.

Melvin, R.L., Stone, B.D., Stone, J.R., and Trask, N.J., 1992, Hydrogeology of thick till deposits in Connecticut: U.S. Geological Survey Open-File Report 92-43, 43 p. (Reprinted as part of Connecticut Department of Environmental Protection Bulletin 20.)

Mullaney, J.R. and Grady, S.J., 1997, Hydrogeology and water quality of a surficial aquifer underlying an urban area, Manchester, Connecticut: U.S. Geological Survey WaterResources Investigations Report 97-4195, 40 p.

Pollock, D.W., 1994, User's guide for MODPATH/MOD-

PATH-PLOT, version 3-Particle tracking post-processing package for MODFLOW, the U.S. Geological Survey finitedifference ground-water flow model: U.S. Geological Survey Open-File Report 94-464, unpaginated.
Prudic, D.E., 1989, Documentation of a computer program to simulate stream-aquifer relations using a modular, finite-difference, ground-water flow model: U.S. Geological Survey Open-File Report 88-729, 113 p.

Ryder, R.B., 1972, Contour map of the bedrock surface, Broad Brook quadrangle, Connecticut: U.S. Geological Survey Miscellaneous Field Study Map MF-451-A, scale 1:24,000.

Starn, J.J., Stone, J.R., and Mullaney, J.R., 2000, Delineation and analysis of uncertainty of contributing areas to wells at the Southbury Training School, Southbury, Connecticut: U.S. Geological Survey Water-Resources Investigations Report 00-4158, $53 \mathrm{p}$.

U.S. Geological Survey, 1995, National handbook of recommended methods for water-data acquisition, Chapter 11-Water use: U.S. Geological Survey Office of Water Data Coordination, available online at http://water.usgs.gov/pubs/chapter11/ 


\section{Appendix 2. Load Estimates from ESTIMATOR}

Table 2-1. Load estimates from ESTIMATOR Log-Linear Regression for U.S. Geological Survey station 01184490, Broad Brook at Broad Brook, Connecticut.

\begin{tabular}{|c|c|c|c|}
\hline Water year & $\begin{array}{l}\text { Annual load, } \\
\text { in pounds }\end{array}$ & $\begin{array}{l}\text { Lower limit of 95-percent } \\
\text { confidence interval, in pounds }\end{array}$ & $\begin{array}{l}\text { Upper limit of 95-percent } \\
\text { confidence interval, in pounds }\end{array}$ \\
\hline \multicolumn{4}{|c|}{ Total nitrogen } \\
\hline 1993 & 231,000 & 221,000 & 242,000 \\
\hline 1994 & 229,000 & 220,000 & 239,000 \\
\hline 1995 & 181,000 & 175,000 & 188,000 \\
\hline 1996 & 267,000 & 254,000 & 281,000 \\
\hline 1997 & 270,000 & 257,000 & 284,000 \\
\hline 1998 & 243,000 & 234,000 & 254,000 \\
\hline 1999 & 182,000 & 175,000 & 188,000 \\
\hline 2000 & 228,000 & 220,000 & 237,000 \\
\hline 2001 & 194,000 & 187,000 & 202,000 \\
\hline 2002 & 117,000 & 113,000 & 122,000 \\
\hline 2003 & 224,000 & 215,000 & 233,000 \\
\hline 2004 & 248,000 & 237,000 & 259,000 \\
\hline \multicolumn{4}{|c|}{ Nitrite plus nitrate nitrogen } \\
\hline 1993 & 178,000 & 171,000 & 186,000 \\
\hline 1994 & 180,000 & 173,000 & 188,000 \\
\hline 1995 & 156,000 & 150,000 & 163,000 \\
\hline 1996 & 200,000 & 190,000 & 209,000 \\
\hline 1997 & 209,000 & 199,000 & 220,000 \\
\hline 1998 & 192,000 & 184,000 & 201,000 \\
\hline 1999 & 151,000 & 145,000 & 157,000 \\
\hline 2000 & 187,000 & 179,000 & 195,000 \\
\hline 2001 & 158,000 & 152,000 & 164,000 \\
\hline 2002 & 106,000 & 101,000 & 111,000 \\
\hline 2003 & 180,000 & 173,000 & 188,000 \\
\hline 2004 & 198,000 & 188,000 & 206,000 \\
\hline \multicolumn{4}{|c|}{ Nitrate nitrogen } \\
\hline 1993 & 176,000 & 168,000 & 184,000 \\
\hline 1994 & 178,000 & 171,000 & 186,000 \\
\hline 1995 & 154,000 & 148,000 & 161,000 \\
\hline 1996 & 197,000 & 188,000 & 207,000 \\
\hline 1997 & 207,000 & 196,000 & 218,000 \\
\hline 1998 & 190,000 & 182,000 & 199,000 \\
\hline 1999 & 149,000 & 143,000 & 156,000 \\
\hline 2000 & 185,000 & 177,000 & 193,000 \\
\hline 2001 & 156,000 & 150,000 & 162,000 \\
\hline 2002 & 105,000 & 100,000 & 110,000 \\
\hline 2003 & 178,000 & 171,000 & 186,000 \\
\hline 2004 & 195,000 & 185,000 & 204,000 \\
\hline
\end{tabular}


Table 2-1. Load estimates from ESTIMATOR Log-Linear Regression for U.S. Geological Survey station 01184490, Broad Brook at Broad Brook, Connecticut.-Continued

\begin{tabular}{|c|c|c|c|}
\hline Water year & $\begin{array}{l}\text { Annual load, } \\
\text { in pounds }\end{array}$ & $\begin{array}{l}\text { Lower limit of 95-percent } \\
\text { confidence interval, in pounds }\end{array}$ & $\begin{array}{c}\text { Upper limit of 95-percent } \\
\text { confidence interval, in pounds }\end{array}$ \\
\hline \multicolumn{4}{|c|}{ Total ammonia plus organic nitrogen } \\
\hline 1993 & 54,600 & 41,400 & 70,800 \\
\hline 1994 & 46,400 & 37,400 & 57,000 \\
\hline 1995 & 22,400 & 19,400 & 25,700 \\
\hline 1996 & 72,200 & 46,700 & 107,000 \\
\hline 1997 & 46,500 & 37,100 & 57,600 \\
\hline 1998 & 42,400 & 32,200 & 54,700 \\
\hline 1999 & 26,000 & 20,600 & 32,500 \\
\hline 2000 & 34,900 & 27,700 & 43,300 \\
\hline 2001 & 37,700 & 25,300 & 54,200 \\
\hline 2002 & 11,100 & 9,610 & 12,800 \\
\hline 2003 & 38,400 & 31,600 & 46,100 \\
\hline 2004 & 48,000 & 37,200 & 60,500 \\
\hline \multicolumn{4}{|c|}{ Total phosphorus } \\
\hline 1993 & 9,320 & 6,820 & 12,500 \\
\hline 1994 & 8,610 & 6,680 & 10,900 \\
\hline 1995 & 4,300 & 3,650 & 5,030 \\
\hline 1996 & 14,400 & 9,140 & 21,600 \\
\hline 1997 & 11,000 & 8,280 & 14,200 \\
\hline 1998 & 9,280 & 7,060 & 12,000 \\
\hline 1999 & 5,690 & 4,350 & 7,310 \\
\hline 2000 & 8,040 & 6,260 & 10,200 \\
\hline 2001 & 8,030 & 5,220 & 11,800 \\
\hline 2002 & 2,330 & 1,970 & 2,740 \\
\hline 2003 & 7,930 & 6,450 & 9,650 \\
\hline 2004 & 9,940 & 7,580 & 12,700 \\
\hline \multicolumn{4}{|c|}{ Dissolved phosphorus } \\
\hline 1993 & 6,390 & 4,740 & 8,430 \\
\hline 1994 & 6,140 & 4,700 & 7,880 \\
\hline 1995 & 3,250 & 2,670 & 3,910 \\
\hline 1996 & 9,090 & 6,380 & 12,600 \\
\hline 1997 & 8,630 & 6,280 & 11,600 \\
\hline 1998 & 6,350 & 4,900 & 8,080 \\
\hline 1999 & 4,120 & 3,080 & 5,400 \\
\hline 2000 & 5,750 & 4,520 & 7,210 \\
\hline 2001 & 4,900 & 3,500 & 6,680 \\
\hline 2002 & 1,540 & 1,280 & 1,830 \\
\hline 2003 & 5,860 & 4,610 & 7,340 \\
\hline 2004 & 7,930 & 5,760 & 10,600 \\
\hline
\end{tabular}


Table 2-1. Load estimates from ESTIMATOR Log-Linear Regression for U.S. Geological Survey station 01184490, Broad Brook at Broad Brook, Connecticut.-Continued

\begin{tabular}{|c|c|c|c|}
\hline Water year & $\begin{array}{l}\text { Annual load, } \\
\text { in pounds }\end{array}$ & $\begin{array}{l}\text { Lower limit of 95-percent } \\
\text { confidence interval, in pounds }\end{array}$ & $\begin{array}{c}\text { Upper limit of 95-percent } \\
\text { confidence interval, in pounds }\end{array}$ \\
\hline \multicolumn{4}{|c|}{ Base-flow nitrate nitrogen load } \\
\hline 1993 & 155,000 & 149,000 & 161,000 \\
\hline 1994 & 157,000 & 151,000 & 164,000 \\
\hline 1995 & 142,000 & 137,000 & 147,000 \\
\hline 1996 & 177,000 & 169,000 & 185,000 \\
\hline 1997 & 191,000 & 180,000 & 202,000 \\
\hline 1998 & 174,000 & 166,000 & 181,000 \\
\hline 1999 & 127,000 & 123,000 & 131,000 \\
\hline 2000 & 171,000 & 165,000 & 178,000 \\
\hline 2001 & 140,000 & 135,000 & 144,000 \\
\hline 2002 & 88,700 & 84,800 & 92,800 \\
\hline 2003 & 154,000 & 149,000 & 160,000 \\
\hline 2004 & 181,000 & 172,000 & 189,000 \\
\hline \multicolumn{4}{|c|}{ Base-flow dissolved phosphorus } \\
\hline 1993 & 2,170 & 1,730 & 2,680 \\
\hline 1994 & 2,330 & 1,760 & 3,020 \\
\hline 1995 & 1,770 & 1,490 & 2,080 \\
\hline 1996 & 2,740 & 2,090 & 3,530 \\
\hline 1997 & 3,000 & 2,090 & 4,170 \\
\hline 1998 & 2,640 & 2,070 & 3,320 \\
\hline 1999 & 1,540 & 1,300 & 1,810 \\
\hline 2000 & 2,520 & 2,070 & 3,040 \\
\hline 2001 & 1,930 & 1,580 & 2,330 \\
\hline 2002 & 976 & 783 & 1,200 \\
\hline 2003 & 2,200 & 1,830 & 2,620 \\
\hline 2004 & 2,680 & 2,110 & 3,350 \\
\hline
\end{tabular}




\section{通}

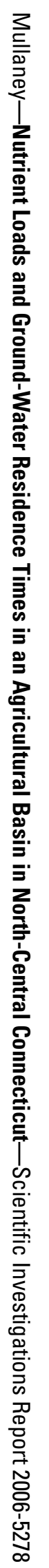

